\title{
TREATIES AND CONGRESSIONAL-EXECUTIVE OR PRESIDENTIAL AGREEMENTS: INTERCHANGEABLE INSTRUMENTS OF NATIONAL POLICY: "I
}

\author{
MYRES S. MCDOUGAL $\dagger$ AND ASHER LANS $\ddagger$
}

\section{The Requirements of a Democratic Foreign Policy for the Whole Nation}

The existence under our Constitution of the variety of interchangeable techniques, described in the previous Sections of this article, ${ }^{1}$ for perfecting international agreements has obviously served the nation well in the past. It may in the future, ${ }^{2}$ if the facts of variety and interchangeability are fully recognized and acted upon by the public and by all branches of the Government, provide a system for the conduct of our foreign relations which is adequate both to cope with the imperatives of survival and to secure our other national interests in the contemporary world - that is, a system whereby policy is quickly and easily formed by democratic means for the nation as a whole, and whereby the execution of policy is prompt and efficient, without being subjected to the adventitious whims and disintegrating attacks of obstructionist minority control. The flexibility and dispatch which such a system may require are available in the President's powers to make the initial decision as to how any particular agreement is to be perfected and to make and perform, on his own responsibility, all agreements needed to meet war and other emergencies. Conversely, ample check upon any arbitrary or unwise exercise of executive power, beyond what is imposed by public opinion and the President's unique responsibility to the voters of the whole nation, is insured by the fact that, without the aid of the Congress, the powers of the President, or even of the President and the Senate, to perform important international agreements are in the long run severely limited. Sooner or later, and in most instances sooner, a President

$\dagger$ William K. Townsend Professor of Law, Yale Law School.

$\ddagger$ Former Comment Editor, Yale Law Journal; sometime University Fellow in the Faculty of Political Science, Columbia University.

The first six Sections of this article were published in the March 1945 issue of the Journal (54 YALE L. J. 181) and are herein cited as Part I. Sections VII and VIII were sent to press before the San Francisco conference convened. Changes have been made only with respect to the most important developments since that date.

For a list of the short-form citations used in this article see Part I, pp. 181-2.

1. See Part I, especially Section IV.

2. It may be assumed that practices which have their origin in the beginnings of our national history and which have developed through 150 years in the actions of Congresses and Presidents, consistently sustained by the courts, have their roots deep in the conditions and "felt necessities" of our national existence and that these conditions and necessities are not likely to change overnight. 
who is engaged in important international undertakings must secure funds and supplementary legislation and must, therefore, submit his negotiations to the scrutiny and approval or disapproval of a majority of the elected representatives of the people. Full and free responsiveness to democratic control and to the national interest can be made certain by use of the Congressional-Executive agreement as a functional alternative to the treaty, enabling the President to go to both houses of the Congress for confirmation of any particular agreement, either in the first instance, or after it has become apparent that an agreement previously submitted to the Senate will be blocked by a minority obdurate in opposing majority will. In such a system the survival, as a sort of constitutional vermiform appendix, of an additional undemocratic mode of validating international agreements by the two-thirds vote of a single house, can do no harm to the national interest, if it is agreed by all parties that this mode of validation is not exclusive of the more democratic mode and that its continued existence is not to be used to obfuscate issues of substantive policy by the invacation of procedural subtleties.

It is an unfortunate fact, however, that the argument is still made, not only that the Congressional-Executive agreement is an illegitimate offspring from the Constitution (a contention thoroughly refuted in the preceding Sections of this article), but even that the treaty-maling procedure, despite its subjection to minority veto and its susceptibility to control by sectional interests, is preferable to the CongressionalExecutive agreement-making procedure on grounds of policy. It may be recalled that Professor Borchard, for example, has gone so far as to characterize "the fashion to extol the executive agreement as an exemplification of -democracy as opposed to the so-called undemocratic requirement of a two-thirds vote in the Senate" as "subversive propaganda." 3 Just as it has been shown that there are no legal reasons for preferring the treaty to the executive agreement, it becomes necessary, therefore, to show, that there are likewise no policy grounds for giving exclusiveness or even pre-eminence to the treaty. On the face of things, it would in fact appear that exactly the opposite is true and that the Congressional-Executive agreement is much to be preferred. It may be agreed that it is undemocratic and undesirable for a President to determine important aspects of our foreign policy by himself, when conditions permit public debate and reference to the other representatives of the people, and that it is maladroit statesmanship for a President to make important agreements without first assuring himself of the cooperation of Congress. Surely, however, in a democratic state whose sectional lines are obsolete in so far as over-all international interests are concerned, any procedure which makes the perfecting of

3. Borchard, Extraterritorial Confiscalions (1942) 36 Arr. J. Isr. L. 275, 281. 
international agreements dependent upon the minority veto of a single house, and the less representative house at that, of a bicameral legislature is an indefensible anachronism that can be tolerated only so long as it makes no difference in the determination of policy. None of the criteria which limit the desirability of simple Presidential agreements has any application to Congressional-Executive agreements. Contrariwise, it is believed that a thorough examination of the relevant policy considerations will conclusively demonstrate what appears on the surface, that the Congressional-Executive agreement is more in accord with the basic principles of American government and more responsive to the national interest than is the treaty. ${ }^{4}$ Such an examination requires, first, an attempt to ascertain, and to appraise the contemporary relevance of, the reasons the Framers might have had for putting into the Constitution an admittedly undemocratic method for securing the approval of international agreements; next, a summary of the record of the Senate in thwarting majority control and the national interest; and, finally, an evaluation of the treaty and CongressionalExecutive agreement in the light of the accepted working principles of democratic government, including brief consideration of some misleading analogies frequently cited by the acolytes of minority control.

\section{The Undemocratic Origins of the Treaty Clause.}

"History sets us free and enables us to make up our minds dispassionately whether the survival which we are enforcing answers any new purpose when it has ceased to answer the old."

\section{Mr. JUSTICE HOLMES.}

From the fragmentary records of the debates at the Constitutional Convention in 1787 and the welter of conflicting views expressed at the state ratifying conventions, three salient facts emerge. In the first place, the delegates to the Convention devoted comparatively little attention to consideration of the means by which the proposed new federal government was to conduct its foreign policy. The question

4. The choice by a President as to whether a treaty, a Congressional-Executive agrecment, or a simple Presidential agreement should be utilized to handle any given diplomatic problem is, of course, dependent upon a larger number of political and psychological variables, such as the need for support from the House of Representatives to implement the agreement, the chances at the moment of getting a two-thirds vote of the Senate in support of a treaty and of thus avoiding debates about procedure, the need for debate as a matter of public education, the prevailing attitudes of Congressional leaders on questions of constitutionality and policy, recent precedent with respect to similar matters, accident, or other chance factors. Most of these variables are, however, more relevant to the immediate tasks of statesmanship than to an objective appraisal of the alternative procedures as instruments of long-term policy.

5. Holases, Law in Science and Science in Law in Collected Legal Papers (1921) $210,225$. 
assumed greater importance in certain state ratifying conventions, but primarily only because certain current disputes as to foreign policy were seized upon by the groups opposing ratification of the Constitution to bulwark their arguments. ${ }^{\circ}$ Secondly, with a few exceptions, the delegates to the Philadelphia Convention sought to remove the determination of foreign policy at least in the immediate future as far as possible from popular control. ${ }^{7}$ Finally-as has previously been demonstrated ${ }^{8}$ - the language the Framers adopted clearly permits utilization of other methods than that provided in the treaty clause for securing validation of international agreements, thus exemplifying their general realization that it was desirable to grant future generations ample freedom to devise appropriate instruments by which to govern themselves. ${ }^{9}$

The federal government created by the Articles of Confederation, like that which had existed from the beginning of the Revolution, had consisted merely of a unicameral legislature and of its subordinate agents. The active control of foreign affairs had been vested in a Congressional committee, working at various times through a secretary and a directing board which, in addition to supervising the negotiation of agreements afterwards ratified as treaties, had consummated compacts with other nations on its own responsibility. ${ }^{10}$ In these early Congresses, which, although controlling foreign policy, essentially functioned as councils of ambassadorial delegates from a group of federated states, ${ }^{11}$ no attempt was made to predicate representation upon population; each state was entitled to one rote. The assent of nine states was necessary to ratify treaties under the Articles of Confederation.

The initial references to the conduct of foreign affairs at the Constitutional Convention were concerned primarily only with the in-

6. See note 40 infra.

7. See notes 28 and 29 infra.

8. See Part I, Section III.

9. See especially former delegate Abraham Baldwin's remarlss in Congress in 1796 in Annals of Congress (1th Cong., 1st Sess.) 537; see also letter from Geonge Washington to Patrick Henry quoted in Warren, Tae Maning of tae Cosstirumo: (1937) 728; Charles Pinckney's speech in the South Carolina ratifying convention in 1788, 4 ELLJOT, DEBatEs, at 261.

10. See Anderson, American Govermarent (1938) 35-50; Swister, Aurericai Constitutronal Developarent (1943) 17-24; Guggenheimer, The Detalofment of the Executive Departments, 1775-1789 in Jasreson (ed.), Essays $m$ tre Constrututional History of the United States (1889) 116-85; Rogers, The Arrenicaii Senate (1926) $58-9$.

11. See ANDERson, op. cit. supra note 10, at 45. Article III of the Articles of Confederation provided that the "said states hereby severally enter into a firm league of friendship with each other," but Article VI forbade the individual states to send or receive ministers from foreign governments or without Congress's consent to enter into any "conference, agreement, alliance, or treaty" with such governments. 
ability of the existing federal government to enforce compliance by the states with the provisions of international agreements. Indeed the Virginia plan of a new Constitution, drafted it is believed primarily by

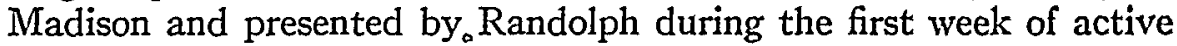
deliberations in May 1787, contained no reference to the location of the power to make treaties. ${ }^{12}$ The New Jersey plan, also presented in the first weeks of the Convention, allotted the power to make treaties to the unicameral Congress it proposed to establish. ${ }^{13}$

There seems to have been no further discussion of the location of the treaty-making power until August 6,14 when the Committee on Detail reported to the Convention the first draft of the Constitution. ${ }^{16}$ During the preceding months the Convention had been preoccupied with its major practical problem, that of evolving a compromise between the representation theories of the large and the small, "the commercial and the non-importing" states. ${ }^{16}$. When the Committee on Detail reported, the compromise plan had been developed of according the states equal representation in the Senate, and of allocating voting power in the House of Representatives on the basis of population. The evidence indicates that the jealousy of the small states "made it indispensable to give to the senators, as representatives of states, the power of . . . ratifying treaties." 17 But when the Committee's proposal for according the Senate exclusive control of the treaty-making power came before the Convention for debate on August 23, almost every speaker raised objections. ${ }^{18}$ The first general set of criticisms, based in part upon the growing realization of the importance of establishing an independent and effective Executive, was directed to the

12. The plan is reprinted in 1 FARRAND, RECORDS, at 20-3. As to the formulation of the Virginia plan, see $3 i d$. at app. A, xv, xvi, xxxii, cccviii, ccclvi, ccclsxxviii, cccxcii, cccxcvii, cccci. Professor Farrand points out that the written draft of the plan was in Madison's handwriting. $1 i d$. at 23, n. 16.

Even granting the assumption that the proponents of the Virginia draft intended the power to make treaties to remain in Congress, it is impossible to tell whether one or both, and if so which, house of Congress was intended to exercise this power.

13. The New Jersey plan is reprinted in 1 FARRAND, RECorDs, at 242-5.

14. Charles Pinckney's plan, presented on the same date as the Virginia plan but never debated, proposed to establish a somewhat unique bicameral legislature and also proposed that treaties be made by two-thirds vote of both houses. See 3 FARRAND, RECORDS, at 604-9. The Hamilton plan, which was not seriously considered, suggested that treaties be made by the Executive with consent of the Senate majority. See 1 id. at 291; Farrand, The Framing of the Constitution (1913) 89. A number of other delegates also thought the Executive should be authorized to make treaties. See, e.g., 2 FARRAND, RECORDS, at 297.

15. 2 id. at 177.

16. See The Federauist, No. 62 (Hamilton or Madison); McLaugulin, Constrtutional History, cc. 13-15; FarRand, The Franing of the Constitution (1913) c. 7.

17. William Davie, who had been a delegate to the Philadelphia Convention, speaking before the North Carolina ratifying convention. 4 Ellior, DEBATES, at 120.

18. See Edmund Randolph's remarks quoted in 2 FARRAND, RECORDS, at 393. 
exclusion of the President; ${ }^{19}$ the second group of objections was based upon the omission of the House from the treaty-making process. $=$ Accordingly, the treaty clause was remitted to the Committee on Unfinished Business, which proposed, on September 4, 1787, that "the President by and with the advice and consent of the Senate, shall have power to make treaties . . ." but that consent of two-thirds of the Senate be required. ${ }^{21}$

Twice the Pennsylvania delegates proposed that the House be associated with the Senate in the ratification of treaties; both times the proposal was defeated, with their state casting the only affirmative ballot. ${ }^{22}$ While it was subsequently stated that exclusion of the House was necessary to retain the adherence of the small states to the union, ${ }^{23}$ relatively few suggestions of this character were made at the Convention itself. ${ }^{24}$ However, the debates at both the Philadelphia and the state conventions, as well as the subsequent comments of delegates, clearly reveal that a compelling reason for exclusion of the House was the belief that it was not suited to participate in the task then contemplated for the Senate, that of participating equally aith the President in the detailed negotiation of treaties. ${ }^{25}$ As a sheer question of expediency, it was felt that the House was too large to maintain the secrecy and dispatch deemed requisite in negotiation. This point was emphasized by Washington, by Hamilton and Jay in The Federalist, and by a great number of delegates to the conventions. ${ }^{26}$ Thus Major Pierce Butler,

19. $2 i d$. at $392-1$.

20. $2 i d$. at 394 .

21. 2 id. at 498-9.

22. 2 id. at $392-4,538$. However, on the first vote on this question, the North Carolina delegation was evenly divided. A number of individual delegates from other states also favored the Pennsylvania proposal.

23. See [Congressman Sol] Bloos, Tae Treaty-Miaking Power (1944) 10; sprach cited supra note 17.

24. But see 2 FARRAND, Reconds, at 393.

25. The testimony of delegates to the Constitutional Convention clearly indicates the intention of the draftsmen that the Senate participate equally with the President in the stepby-step negotiation of treaties. See Hamilton's remarks in TaE FEDERAuIst, No. 75; Gen. Pinckney's remarks to the South Carolina ratifying convention, 3 FarRasid, Reconos, at 250; Rufus King's speech in the Senate on Jan. 12, 1818, 3 id. at 424. Madicon even suggested that the Senate be permitted to malee treaties of peace without the President. See 2 id. at 393-5.

Congress had actually superintended the negotiation of treaties under the Articles of Confederation. See Bears, A Diplosatic History of teE United Statiss (1942 ed.) 78-50. The circumstances under which President Washington found it necessary to terminate the practice of continuous consultation have been discussed in Part I, Szction II. Sze also Hayden, The Senate and Treaties, 1789-1817 (1920) cc. 1-2.

26. Thus Washington stated in a message to the House of Representatives in 1796: "The necessity of such caution and secrecy was one cogent reason for vesting the pover of making treaties in the President, with the advice and consent of the Senate . . . ." 5 A:NALS of CoNG. 760. The fluctuating membership of the House was another commonly 
who had been a member of the South Carolina contingent at the Philadelphia gathering, declared at his state's ratifying convention:

"The House of Representatives was then named; but an insurmountable objection was made to this proposition-which was, that negoliations always required the greatest secrecy, which could not be expected in a large body." 27

Another decisive reason for exclusion of the House, stemming from the delegates' general distrust of democracy, ${ }^{28}$ was that the Representatives were to be elected by direct suffrage, whereas the President was to be chosen by the Electoral College and the Senate was to be chosen by the state legislatures, and was expected by some to become a "second House of Lords." 20 But this evidence does not prove that the Constitutional Convention wished wholly to exclude the House from participation in the control of the foreign relations of the United States. As Professor Wright has stated, it proves only "that the Convention wished to make it possible for the President to make treaties without submission to the House." 30

In determining the type of Senatorial majority which should be required to permit ratification of treaties, the Constitutional Convention moved with a great deal of uncertainty. As previously indicated, the Report of the Committee on Unfinished Business had proposed that a two-thirds vote should be necessary. ${ }^{31}$ However, on September 7, the

stated reason for its exclusion from the treaty-making process and was especially emphasized in The Federatist. For statements of delegates and contemporaries as to these and other factors see 2 FARrand, Records, at 538; 3 id. at 250, 424; Crandall, Trenties, at 61; 2 Elliot, Debates, at 505; 4 id. at 280; The Federalist, No. 64 (Jay) and No. 75 (Hamilton).

27. Quoted in Bloom, op. cit. supra note 23, at 12.

28. The most persuasive statement of the reasons for keeping the treaty power out of popular control was made by Jay in THe. FEDERALIST, No. 64. The record of the debates at the Constitutional Convention are replete with statements indicative of the anti-Democratic feelings of many of the delegates. See, e.g., 1 FARRAND, REcords, at 426-8; Rogers, TuE American Senate (1926) 17-18. For discussions of this aspect of the Constitution by recent scholars see BEARd, AN Economic InTERpREtation of tHe Constitution of tuie United States (1935 ed.); Schlesinger, New Viewpoints in AMERICAN History (1922) c. 4; Rogers, supra at 17-18.

29. Delegate Dickinson, who introduced the resolution providing for indirect designation of Senators, quoted in Rogers, op. cit. supra note 28, at 17-18. Gouverneur Morris hoped "that the Senate will show us the might of aristocracy." Quoted in ForD, TuE RIsE and Growth of American Politics (1898) 53. Under Article I, Section 3, paragraph 1 of the Constitution, the Senators were to be selected by the state legislatures; it was not until 1913 that the Seventeenth Amendment was adopted providing for direct election of the members of the upper house. The expectations of the draftsmen as to the manner in which the Electoral College would screen out popular sentiment in the selection of the President are outlined in Part I, Section IV.

30. Wright, The United States and International Agreements (1944) 38 AM. J. INT. L. 341, 350. See Part I, Section III, for fuller discussion.

31. 2 FARRAND, RECORDS, at 498. 
Convention adopted Madison's proposal that treaties of peace should require assent of a mere majority of the Senate; ${ }^{32}$ the very next day, the amendment was struck out by exactly the same margin by which it had previously been adopted! ${ }^{33}$ On September $S$, the Convention also considered a variety of proposals for changing the general requirements for treaty approval, defeating, inter alia, suggestions that assent of two-thirds of the whole Senate or two-thirds of an enlarged quorum be required..$^{34}$ The shaky foundations of the present two-thirds rule are best indicated by the fact that Roger Sherman's motion during the last week of the Convention that treaties require only approval of "a majority of the whole number" (of the Senate) was defeated only by a 6-5 vote. ${ }^{35}$ Thereafter, the delegates, eridently "growing tired," is finally accepted the two-thirds rule. ${ }^{37}$ As Professor Fleming has observed:

"The change of one state delegation, probably of one man in a divided delegation, would have given us this provision instead of the two-thirds vote, and we should have revered that arrangement as an expression of the Convention's great wisdom instead of looking up to its inspired action in fixing the higher majority." 53

Historians have expounded a variety of theses to explain the ultimate retention of the two-thirds rule. Thus Mr. Charles Warren has suggested that the Southern states insisted upon this undemocratic limitation to prevent the New England and Middle Allantic states from surrendering their claim to navigate the Mississippi to its mouth." Mr. Warren's thesis as to the intention of the Framers is primarily based on excerpts from the debates at ratifying conventions ${ }^{40}$ and

32. $2 i d$. at 540. The Convention, however, rejected another proposal by Madicon -that affirmative vote of two-thirds of the Senate would suffice to malie a treaty of pasce "without concurrence of the President." 2 id. at 510-1.

33. 2 id. at 544 .

34. 2 id. at 549 .

35. Ibid.

36. Farrand, The Fraimig of the Constitution (1913) 171.

37. 2 FARRAND, RecoRDs, at 550 .

38. Fleming, The Treaty Veto of the Aurericar Semate (1930) 306. Alemander Hamilton, the only New York delegate then in attendance at the sessions, did not vote on any of these proposals dealing with the Senatorial vote. As previously indicated (stipra, note 14), Hamilton had indicated his belief that majority approval by the Senate should suffice.

39. Warten, The Mississippi Rizer and the Trealy Clause of the Constitulion (1934) 2 Geo. WASH. L. REv. 271.

40. Unquestionably a large number of delegates to the ratifying conventions coming from the western portions of Virginia, North Carolina, and Pennsylvania argued that even the two-thirds rule was insufficient protection against the possibility of cession of disputed land to the Indians or surrender of navigation rights on the lower Mieziszippi. Sae McMIster and Stone (eds.), Pennsylvania and the Federal Convention (1838) $476 ; 3$ Elliot, Debates, at 151-2, 239-10, 311-2, 333-66. Benns, Pincerey's Treaty (1926) 173. But 
other extrinsic material as to the importance of the dispute over navigation of the Mississippi the records of the Constitutional Convention are inconclusive as to the validity of this interpretation. ${ }^{41}$ Moreover, it is difficult to reconcile this thesis with the position taken by Madison and Jefferson in the mid-1790s-when interest in navigation of the Mississippi had greatly increased-that commercial arrangements with other nations should be made only by both houses of Congress and by majority vote. ${ }^{42}$ Other writers have suggested that the desire of the New England states to ensure protection of their claim to fishing rights off the Newfoundland coast or of those states with unsettled western frontiers to prevent ratification of over-generous Indian treaties were sectional interests which impelled retention of the two-thirds rule. ${ }^{43}$ More recently Professor Borchard has made the wholly novel suggestion that the "desire of the small states to prevent imposition of treaties by a mere majority" was an important factor underlying the twothirds requirement. ${ }^{44}$ For these suggestions the records of the Federal Convention are devoid of supporting evidence.

An instructive yardstick of the plausibility of the speculations that the Convention was motivated by an insistence on protection of small

few delegates from these portions of the country were present at the Constitutional Convention.

George Washington commented on these Cassandrish objections made at the ratifying conventions in unwontedly strong language:

". . . every art that could inflame the palsions or touch the interests of men

has been essayed. The ignorant have been told that should the proposed Government obtain, their lands would be taken from them and their property disposed of. And all ranks are informed that the prohibition of the navigation of the Mississippi (their favorite object) will be a certain consequence . . . ."

Washington to General Lincoln, April 2, 1788, quoted in Warren, supra note 39, at 297.

41. The only delegate who is reported in Farrand's records of the debates at the Constitutional Convention as directly discussing the relation of the Mississippi and fisheries convention to the treaties clause is Gouverneur Morris, and it is difficult to tell whether he thought the two-thirds requirement would in the long run afford more or less protection to these sectional interests. See 2 FARRAND, RECoRDS, at 548. There was, however, further discussion of these sectional interests during the protracted debate on the basis of representation in Congress.

Subsequently Delegate Williamson of North Carolina recollected that protection of the right to navigate the Mississippi had been presented as one reason for insistence on a twothirds requirement. $3 i d$. at 306-7; 4 DocunENTARY History OF THE Constitution (1905) 677-8. George Mason (who campaigned against adoption of the Constitution) subsequently asserted that the desire to protect the fisheries also impelled adoption of the two-thirds rule. 3 Elliot, Debates, at 604.

42. See Part I, pp. 236, 238-9.

43. See McClendon, Origin of the Two-Thirds Rule in Senate Action Upon Traties (1931) 36 Ams. Hist. Rev. 768; Whitaker, The Spanish-Anderican Frontier, 1783-1795 (1927) 123-6; Tansill, The Treaty-Making Powers of the Senate (1924) 18 AM. J. INT. L. 459.

44. Borchard, Executive Agreements, at 666. It is a little hard to see why, in a body where the states were equally represented, the small states needed protection against a "mere majority" any more than did their larger neighbors. 
states or protection of sectional interests against the possibility of untoward action by an inconsiderate majority may be furnished by the record of votes on Roger Sherman's proposal to permit assent to treaties by a majority veto; ${ }^{45}$ for every one of the five states which supported the majority vote proposal should, in light of one or another of these theories, have "protected" itself by holding out for a twothirds requirement. Connecticut (which sponsored the proposal) and Delaware, two of the most active states in the small-state bloc, ${ }^{\circ}$ voted in favor of rule by a "mere majority," as did Massachusetts, which had the largest interest in the fisheries question. South Carolina and Georgia, both possessing frontier areas with unascertained Indian frontiers and interests in navigation of the Mississippi, supported the proposal for majority control, whereas New Hampshire and Maryland, which had no western lands, took the opposite position. ${ }^{47}$.

In all this darkness, it is obviously difficult to assay the exact extent to which transient sectional considerations may have been persuasive in the framing of the treaty-making clause. There is, however, one conclusion it seems safe to draw, and that is the conclusion of Mr. Warren that no justification of the two-thirds rule was ever put forth in terms of political principle. ${ }^{49} \mathrm{Mr}$. Warren has recently stated:

"You will search the debates on the Constitution relative to the insertion of the two-thirds clause, and you will search them in vain to find any political theory on which the two-thirds clause was founded." 49

He adds,

"In other words, there being in the debate no suggestion that this two-thirds provision was based on any political theory of government, and no suggestion as to underlying reasons based on political conditions except that of Gerry [protection of fisheries]you are left entirely free to adopt your own theory as to why it was put in, because no citations of Madison's Debates will stand up as a foundation for the argument either for or against it. I have seen many statements in books and articles and so forth that the twothirds provision was based on this or that theory, or on this or that theory of government, but you will find no such in Madison's Debates." 50

45. 2 FARRAND, RECORDS, at 549.

46. See Madison, Debates, at 101-2.

47. See Warren, supra note 39 , at $285,287,291,295$.

48. Warren, supra note 39, at 272. In his concurring opinion in Dred Scott v. Sandford, 19 How. 393, 526 (U. S. 1857), Mr. Justice Catron said: "The Constitution was framcd in reference to facts then existing or likely to arise: the instrument looked to no theories of Government."

49. Judiciary Committee Hearings at 81.

50. Id. at $\$ 6$. 
Despite Mr. Warren's caution, it seems safe also to infer that one contributing factor to the rigidity of the clause may have been a desire of the delegates-doubtless in a temporary mood of isolationism engendered by surviving war-weariness-to minimize the number of treaties that the new government might make. ${ }^{11}$ Thus Gouverneur Morris declared that "In general he was not solicitous to multiply and facilitate treaties," 52 and James Madison concluded that "it had been too easy $\therefore$ to make treaties" under the existing government. ${ }^{\circ 3}$ It only adds to the paradox and to the mystery of "real intent" to recall that at the same time these draftsmen inserted language into the Con* stitution capable of being construed, as Madison and Jefferson were shortly to argue, to authorize the consummation of agreements by means less difficult than the treaty-making procedure. ${ }^{54}$

\section{The Contemporary Irrelevance of Disputes Far Off and Long Ago.}

The hard-headed statesmen who met at Philadelphia in 1787 were concerned with the practical problem of devising a scheme of government that could unify a disorganized country. Coming from states separated by difficult physical barriers, ${ }^{55}$ jealous of their own governmental prerogatives, ${ }^{56}$ and with economies which in many cases had not yet developed a substantial degree of interdependence, they necessarily wrote a Constitution which was "a bundle of compromises." $b 7$

51. See Holt, Treaties Defeated by the Senate (1933) 10-11; Foster, Practice of Diplomacy (1906) 263.

52. 2 FARRAND, RECoRDS, at 393. See also Rufus King's remarks in the United States Senate on Jan. 12, 1818. 3 id. at 424.

53. 2 id. at 548. By 1787, the United States during eleven years of independence had entered into the enormous total of fifteen treaties. 3 MaLloy, TrEATIES, at ix. For contemporaneous statements, akin to those of Morris and Madison, see 4 Wuitings of Samuel Adams (Cushing, ed., 1908) 281; 8 Works of John Adass (C. F. Adams, ed., 1853) 37; 2 Rowland, LifE of George Mason (1892) 47.

54. See Part I, Section III. See also 5 Annals of Congress 488, 580, 625, 778 (4th Cong., 1st Sess., 1796). During the same debate, Congressman Holland of North Carolina, who had been a delegate to the ratifying convention in his state, said that the Constitution had been adopted therein only on the express understanding that the treaty-making power was restricted in the case of commercial agreements by the grant of authority to Congress to control foreign commerce. $I d$. at 546.

55. In 1787 it took four days to travel from Boston to New York City or Albany, five days to Philadelphia or Maine, seven days to Baltimore, eleven to Pittsburgh or North Carolina, eighteen to Georgia. See Staley, World Economy in Transition (1939) 11-12.

- 56. See 4 Elliot, Debates, at 120; letters by George Washington, quoted in Warren, supra note 39 , at $271,297$.

57. 1 Beard, Rise of Asierican Civilization (1927) 317. The authors further $c$ aracterized the Constitution, as "a mosaic of second choices." Ibid. Professor Farrand has commented: "Our Constitution was a practical piece of work for very practical purposes. It arose from the necessity of existing conditions. It was designed to meet certain specific needs." Farrand, The Federal Constitution and the Defects of the Confedcration (1908) 2 AM. Pol. Scr. REv. 532, 543. 
The great aim of the Framers-"to make our states one as to all foreign concerns" "s _ has become increasingly important in the past 150 years. There is no longer any political necessity to hamper its complete attainment by deference to a minority veto by one house of the Congress over international agreements. The geographical isolation, the jealousies, and the separatist movements of 1787 are now of significance only to historians or to those who seek to convert the Constitution into a Procustean bed. "The dead cannot bind the living." Even if it be assumed, contrary to the known facts, that there was no confusion among the Framers about the treaty-making clause, we are unworthy of our heritage as free Americans unless ve are willing to reassay its utility in light of the political and economic necessities and ideas of our own time. Long ago Jefferson wrote:

"Some men look at constitutions with sanctimonious reverence, and deem them like the ark of the covenant, too sacred to be touched. They ascribe to the men of the preceding age a wisdom more than human, and suppose what they did to be beyond amendment. I knew that age well; I belonged to it, and labored with it. It deserved well of its country. It was very like the present, but without the experience of the present; and forty years of experience in government is worth a century of book-reading; and this they would say themselves, were they to rise from the dead. . . . Let us . . . avail ourselves of our reason and experience, to correct the crude essays of our first and unexperienced, although wise, virtuous, and well-meaning councils." 69

Considered in this spirit, the most significant fact about the motives which are supposed to have impelled the Framers to exclude the House of Representatives from the treaty-making process and to require the Senate to give its consent by a two-thirds majority is that none of them have any validity today; most indeed were outmoded within fifty years after the drafting of the Constitution.

1. The Exclusion of the House. Three of the four possible reasons for establishing a procedure whereby international agreements could be made without reference to the House-the necessity for secrecy and speed, the short term of its members, and the fluctuating membership of the body-are admitted to be without significance even by so stalwart a critic of "recent trends" as Professor Borchard. " The increase

58. Letter from Jefferson to Washington, Aug. 14, 17S7, quoted in Warren, TrE Making of the Constirution (1937) 451.

59. Letter to Samuel Kercheval, July 12, 1816, 15 Writmos of Trous Jefrenso:i (Library ed. 1904) 40-2.

60. Borchard, Escecutire Agreements, at 666; see also BLoos, op. cil. stspre note 23, at 10-13.

The suggestion by Professor Borchard, in Executire Agreemen/s at 683, that a majority vote of both houses might be more difficult to obtain than a two-thirds vote of the Senate is not only inconsistent with his major position as to the desirability of malsing it dificult to effect international agreements, but is a dubious prophecy, based on questionable history. 
in the size of the Senate to a point where it includes almost twice as many members as did the House in 1789 and the abrogation by George Washington of the Senate's role as an executive council guiding the conduct of negotiations have invalidated these considerations.

It is equally difficult to see how it can reasonably be asserted in 1945 that the fourth alleged reason-the jealousy of the small states and their resistance to an electoral system based on population-has not also lost its meaning. The jealousies born of quondam new independence have been merged by a century and a half of national history into a realization of the basic and irrevocable mutuality of international interests. The small states as such have no group interest in foreign affairs distinguishable from those of their larger neighbors. The interests of Delaware, for example, would be difficult to distinguish from those of Pennsylvania, and the interests of Nevada from those of California. ${ }^{61}$ The Nazi-Japanese aggressors threatened the freedom and safety of all Americans, and not merely those living in the "large" states.

2. The Two-Thirds Rule. If, as distinguished scholars have concluded, transient sectional economic interests, and particularly the Mississippi Valley controversy, were among the principal reasons for the original inclusion of a two-thirds requirement in the treaty clause, these specific problems have long since been settled. The more significant fact is that the United States-which in 1787 was a loose confederation of states, rife with sectional secession movements ${ }^{62}$-has with the passage of time become welded into a unified nation, the separate geographical regions of which are increasingly interdependent upon each other and upon the welfare of the whole nation for the achievement of all of the values of their people. While there are undoubtedly economic and social questions upon which sectional points of view may conflict, it is difficult to see how these can safely be allowed to prevent the integration of a foreign policy in the interest of the whole nation. As Mr. Justice Field said sixty years ago:

"For local interests the several States of the Union exist, but for national purposes, embracing our relations with foreign nations, we are but one people, one nation, one power." 63

61. What is said with respect to sectionalism in the discussion of the two-thirds rule below is obviously equally applicable to the "small" states.

It is not without relevance that Professor Borchard has himself suggested, in attempting to refute figures "designed to show that a small minority of Senators from the populous states could block a large majority of Senators from the less populous states [sic]," that "Senators rarely cast their votes according to the size of their states." Borchard, The Two* Thirds Rule as to Treaties: A Change Opposed (1945) 3 Econ. Council Papers, No. 8, p. 5.

62. See Warren, The Making of The Constitution (1937) 3-54.

63. The Chinese Exclusion Case, 130 U. S. 581, 606 (1889). In Cohens v. Virginia, 6 Wheat. 264, 413-4 (U.S. 1821), Chief Justice Marshall took the same position: 
It may be worthwhile to explore in some detail just what is involved in the suggestion that there are still sectional interests in the country that deserve special protection from the formulation of foreign policy for the whole nation by majority will. ${ }^{6.4}$ The first difficult question is whether all sectional interests or just some sectional interests are to be given this special protection. If all sectional interests, however short-run or however dangerous to the rest of the country, are to be protected, the result is complete disintegration of national policy. As Gouverneur Morris long ago warned the Constitutional Convention, there "can be no end of demands for security if every particular interest is to be entitled to it." 65 If only some sectional interests are to be protected, the problem is to achieve a criterion of selection. The only defensible criterion, other than sheer power, is the public interest, which again comes back to the national interest. If the alternative of sheer power is adopted, ${ }^{66}$ what begins as mere protection of sectional interests is transmuted into determination of national policy without appropriate regard for the national interest. It is obvious that a negative decision on behalf of a single section may have the effect of precluding a positive policy on behalf of the whole nation; in most instances, we either join a particular international organization or enter into a particular agreement or we do not. Those proponents of a minority veto for sectional interests who have a real regard for the national interest are therefore confronted with an irremovable dilemma.

A second question, which takes the sting from this dilemma for those who have a real regard for sectional interests, is why it should be assumed that sectional interests require any more protection from governmental action which includes the making of an international agreement than from governmental action which does not. The events that make up our "foreign affairs" or "foreign relations," the domain in which international agreement operates, and our "domestic affairs" are but interdependent, and often indistinguishable, parts of the total process of institutional activities by which the people of the United

"In war we are one people. In making peace, we are one prople. In all commercial regulations, we are one and the same people. . . America has chosen to be ... a nation."

See also Theodore Roosevelt's remarlis: ". . . little permanent good an be done by" any party which worships the States' rights fetish or which fails to regard the State, lilse the county or the municipality, as merely a convenient unit for local self-government, while in all national matters, of importance to the whole people, the nation is to be supreme over state, country, and town alike." Roosevelt, AutoBrograpry (1925) 397 .

64. This appears to be the real meaning of Profecsor Borchard's suggestion that "the desire of the small states to prevent imposition of treaties by a mere majority" still "retains its cogency." It has been seen that a "small" state, as such, requires no more protcction from a majority than a "large" state.

65. 1 FARRAND, RecoRds, at 604.

66. It needs no emphasis that the use of sectional power, without regard for the national interest, could lead to destruction af the nation. 
States pursue all their values. ${ }^{67}$.The effects of "foreign policy" and of "domestic policy" on any problem of importance are today hopelessly intermingled. It is a fundamental principle of our government that a simple majority of both houses of the Congress should suffice for decision on "domestic matters" - as, for example, the regulation of transportation and the development of drainage basins-which have at least as great an import for peculiar sectional interests as intergovernmental agreements. Were this not the case, the Federal Government would soon be reduced to impotence, and a state of anarchy akin to that which existed in the 1780 s would prevail. Just how is it that sectional interests require that the making of policy for international agreements be distinguished from the making of policy for domestic affairs, and justify an exceptional, undemocratic majority for the former only? In defending retention of the present treaty clause, Professor Borchard has recently suggested that "The western states, for example, would hardly expose themselves to a mere majority vote on oriental immigration." 68 But, as everyone knows, the western states are in fact exposed to this "danger" in the form of general immigration statutes every time the Congress meets.

One may even question the major premise that there are in this country any sectional interests in international affairs that in the long run differ from the interests of the whole nation. Any one section of the country is as much interested as any other in the preservation of our national independence from external encroachment and in the establishment of a community order capable of preventing crises from arising that may precipitate attacks upon our security; when our security system breaks down, every section of the country is put to work, and men are drafted from every section of the country, to repair the breach. Any one section of the country is as much interested as any other in the maintenance of full production, employment, and consumption and in preventing world-wide economic depression, with its consequent impoverishment of our national standard of living. Even where some one section of the country is more interested than any other section in the price of a particular commodity, the price of that commodity is dependent upon all the factors which make up demand, and these factors in turn are ultimately dependent, if the commodity is of any importance, upon the whole economy of the nation. What can thus be shown of the interdependence of all our sections with respect to security and economic prosperity in the formulation and effects of foreign policy. could equally well be shown with respect to all our other major interests. For the long-run achievement of its total values in our inter-

67. Compare the views of Jessup in Judiciary Committee Hearings at 122.

68. Should Treaties Be Ratified by a Majority of Both Houses? (1944) 10 Town MeErina BULLETIN, No. 25, p. 13. 
national affairs, any one section of our country is wholly dependent upon a similar achievement by every other section.

It should need no argument, finally, that, even if there are in this country sectional interests in international affairs that conflict with the over-all national interest, it is the national interest-as determined by national vote, without undue loading of the votes of any section or minority-that must prevail. Even if the transient interests of some particular section do not depend upon the long-term interests of the nation, the nation can only weigh such interests from a national point of view, without giving them special priority by the two-thirds rule or otherwise, over the equal interests of other sections. The simple fact is that a foreign policy for the whole nation must be determined in the interests of the whole nation and not in terms of a short-run interest of one of its parts. Under contemporary world conditions, any other choice can only mean national suicide.

Similar disposition can be made of the other major factor which is believed to have contributed to the two-thirds rule, the desire of the Framers in $1787^{69}$ to minimize the international contacts of the emergent Republic. The pervasiveness of this motive is indicated by John Adams' contemporaneous suggestion that the foreign service be abolished completely or greatly reduced in size. ${ }^{70}$ This short-lived isolationist agoraphobia was undoubtedly bred in large measurecompare the fears and policies of another new State, Soviet Russia, during the $1920 \mathrm{~s}$ - by a desire to prevent the great powers of Europe from interfering in the domestic politics of the then weak nation. ${ }^{71}$

Even as applied to their own age, the transient belief of the Framers in 1787 that it was possible for the United States to live apart from the rest of the world was tinged with a large measure of wilful amnesia and was soon to be thoroughly belied by the trend of events. It has been our habit, perhaps in an excess of national pride, to gloss over the fact that the Revolution itself was part of a general war, in which France, Spain, and the Netherlands joined in fighting against the English, and in which the free use of British sea power was hindered by the League of Armed Neutrality, comprising six other continental States. $^{72}$ During the course of the Revolution, moreover, the Continental Congress consummated a full-fledged alliance with France ${ }^{73}$ and sought to make additional alliances with Spain, the Netherlands,

69. See supra, p. 544.

70. See $S$ Works OF JoEn Adass (C. F. Adams, ed., 1853) 37.

71. The consideration the Framers gave to this problem is indicated by TrE FEDERaLIST, Nos. 5 and 68; see BaILEY, Diploxatic HistoRy, at 57-S, 73-SO, for evidence as to the validity of these fears.

72. See 1 Morison and Comiager, The Growtr of the Aurencas Rerunlic (3d ed. 1942) 218; Beuns, A Diplosatic History of the Usited Stutes (1942 ed.) 29-44.

73. 2 Muler, Treaties, at 35 . 
Prussia, Austria and other States. ${ }^{74}$ Indeed, the preliminary peace agreement with England contained a clause that a permanent treaty would not go into effect until the cessation of hostilities between England and France; ${ }^{75}$ the definitive treaties between the belligerents were all signed on the same day ${ }^{76}$

Nor was the nascent Republic able to steer clear of the "vicissitudes" of European politics. Nine years after the ratification of the Constitution, we were engaged in an undeclared naval war with France; ${ }^{77}$ in 1801, Jefferson initiated a naval war with Tripoli; ${ }^{78}$ a scant 11 years later, we were engaged in a second full-fledged war with England. ${ }^{79}$

Indeed, our early statesmen realized, shortly after the formation of the Union, the futility of any simplified notion that the United States could or should forever abjure "entangling alliances." In his Farewell Address, Washington, while advising against the formation of permanent alliances, indicated the desirability of respecting the existing commitments to France. ${ }^{80} \mathrm{He}$ concluded his discussion of the subject with the oft-forgotten reminder: "Taking care always to keep ourselves by suitable establishments on respectable defensive posture, we may safely trust to temporary alliances for extraordinary emergencies." 81 A similar practical empiricism guided Jefferson. In letters to friends during the early 1800 s he warned that the United States could not permit Napoleon to dominate Europe and that we might have to send an army overseas if this contingency seemed likely to eventuate. ${ }^{82}$ Such declarations of policy, to which were coupled a frank acknowledgment of his error in previously believing that the United States could remain at peace whatever the trend of politics elsewhere, ${ }^{83}$ were climaxed in

74. See Besrs, op. cit. supra note 72, at 34, 41-2. See also the "Act Separate and Secret," annexed to the Franco-American Alliance Treaty of February 6, 1778 to permit Spanish accession thereto, which was ratified by the Continental Congress. 2 Mirler, TrEATIES, at 47 .

75. 2 Mitler, Treaties, at 96.

76. See Besis, op. cit. stipra note 72, at 60-2; see also 2 Milier, Treaties, at 112.

77. See 1 Stat. 561 (1798); 1 Stat. 572 (1798); 1 Stat. 574 (1798); 1 Stat. 709 (1799); ALlen, Our Naval War with France (1909).

78. See 3 McMaster, History of the People of the United States (1928) 201 et seq.; 1 RICHARDSON, MESSAGES, at 326; 2 Stat. 129 (1802).

79. Recent historians have swung away from the view of the 1920s that the War of 1812 was entirely or primarily caused by a desire to conquer Canada, and returned to the older thesis that the casus belli was in large measure grievances resulting from British maritime policy during the Napoleonic wars. See Goodman, The Origins of the War of 1812: A Survey of Changing Interpretations (1911) 28 Miss. VALLEy Hist. Rev. 171; BURT, THE United States, Great Britain, and British North Aarerica (1940) cc. 11-13.

80. 1 Richardson, Messages, at 213, 221-3.

81. Id. at 223.

82. Letter to General Kosciusko, Feb. 26, 1810, 12 Writings of Thosus Jefrerson (Library ed. 1904) 365-9; letter to Thomas Leiper, Jan. 1, 1814, $14 i d$. at 41, 43-5; see also letter to Rnhert Livingston, quoted in LIPPMANN, U. S. ForeIGN Policy (1943) 63-4.

83. "I had [in 1804] persuaded myself that a nation, distant as we are from the conten- 
1823 when Jefferson advised President Monroe to make "a concert, by agreement" with England to prevent Spain or the Holy Alliance from interfering in Latin America.s:

Confronted then with the practical necessity of shifting alignments expeditiously in a kaleidoscopic world, the early Presidents soon found it impossible, as has previously been indicated, to continue to treat the Senate as an active advisory council in the conduct of international affairs and the negotiation of treaties. The belief that the government under the Articles of Confederation had consummated too many treaties was discarded at the same time as the Senate's function was transmuted from an executive to a legislative role, by men who had been leading participants at the Constitutional Convention. ${ }^{35}$

It needs no elaborate demonstration that, however wise the Fathers' original desires "to live alone and like it" may have been in 1789 , in the age of the robot bomb and world economic interdependence, isolationism is bankrupt as a guide to policy. Even persons who disagree violently as to the nature of the foreign policy to be pursued by the United States agree on this. ${ }^{56}$ Having engaged in two World Wars in 25 years, the United States is not likely to decline once again to participate in making the political and economic decisions which can help prevent the recurrence of such wars.

It is sometimes suggested that, though the "originating causes" of

tions of Europe, avoiding all offences to other powers, and not over-hasty in resenting offence from them, doing justice to all, faithfully fulfilling the duties of neutrality, forforming all offices of amity, and administering to their interests by the benefits of our commerce, that such a nation, I say, might expect to live in peace, and consider itself merely as a member of the great family of mankind; that in such case it might devote itself to whatever it could best produce, secure of a peaceable exchange of surplus for what could be more advantageously furnished by others, as tales place between one county and another in France. But experience has shown that continued peace depends not merely on our own justice and prudence, but on that of others also." Letter to Say, Mlarch 2, 1815. 14 Writrics of Thomas JefFenson (Library ed. 1904) 258-9.

84. The quoted phrase was originally used in Monrae's letter to Jefferson and MIadicon, Oct. 17, 1823, requesting advice as to whether to accept the English Prime Mlinister Canning's suggestion to issue a joint declaration against European intervention in Latin America. 6 Writngs of Janes MIonrof (Hamilton, ed., 1902) 323-5. Jefierson's answer, the burden of which is contained in the instant text, is reprinted in 15 Wnitrigs of THous JEFFERSON (Library ed. 1904) $477-S 0$; Madison's answer is reprinted in 6 Wrmisgs of Jajies MIonroe (Hamilton, ed., 1902) 394. However, Monroe, on the advice of his Secretary of State, John Quincy Adams, decided to issue the announcement on his own. Sce Penruis, Hands OfF: A History of The Monkoe Docrkine (1941) 41-50. Iet it was clear that, as a practical matter, we had entered into an unstated partial alliance with England to protect Latin America. See LIPPMLANN, op. cit. supra note \$2, at 16-20.

85. President Washington and Edmund Randolph, who was Secretary of State in 1791, when the Senate's role began to be actively transmuted, had both been delegates to the Constitutional Convention.

86. See Beard, The Orex Door at Hoxe (1934) c. 12; Vandenberg, Lat's Try to Prerent World War III, Saturday Evening Post, March 17, 1945, p. 17. 
the treaty-making procedure have disappeared, there are "many new reasons," ${ }^{87}$ such as "the recent unprecedented inflation of executive power" 88 or the dangers of "secret diplomacy," 89 which justify its retention. These arguments appear to be rooted in a simple failure to differentiate between the two principal classes of executive agreements: those perfected by the President on his own responsibility, and those made in pursuance of Congressional authorization. The Constitution of the United States is, fortunately, sufficiently flexible that it presents no necessity for choosing between the Scylla of a foreign policy dominated by a Senatorial minority and the Chasybdis of simple Presidential agreements. It offers a third and thoroughly democratic alternative: the Congressional-Executive agreement, eliminating both the possibility of arbitrary, injudicious or secret action and the disintegrating effects of minority obstructionism. In view of this alternative, it is clear that those who seek to stigmatize the executive agreement by vague reference to the dangers of unchecked executive power ${ }^{00}$ or to "secret diplomacy" ${ }^{91}$ are invoking the flimsiest of bogeymen in their attempt to perpetuate minority control..$^{22}$ No one believes that

87. Borchard, Book Review (1944) 4 LawXers Guild Rev. 59, 60.

88. See Borchard, Executive Agreements, at 666-7; Gibson, THE Road to Foneign Policy (1944) c. 12.

89. See Mathews, American Foreign Relations (rev. ed. 1938) 545-6; Borchard, Executive Agreements, at 677-8.

90. Moreover, it should be noted that the recent "inflation of executive power" in the field of foreign relations has been an inevitable product of the war. Independent action by the President and widespread delegation of power to the President have been found through = out our history to be indispensable to the successful prosecution of war. See RANDALL, Constitutional Problesis Under Lincoln (1926); Berdarl, War Powers of the ExeCUTIVE (1921).

91. Even as applied to direct Presidential agreements, the possibilities of "secrct diplomacy" are greatly exaggerated. The necessity for securing the consent of Congress in order to secure needed funds is an effective check on the executive's ability to make important commitments. Professor Borchard cites, inter alia, the secret clause attached to the Lansing-Ishii Agreement of 1917 and various recent military defense and armistice agreements. Borchard, Execative Agreements, at 677-8. In the case of the first-named "agreement," neither of the participants, as has previously been indicated, considered that anything more than an exchange of diplomatic views had taken place. The agreement, moreover, was a desperate effort by the United States to preserve the status quo in China, at a time when its energies were unavoidably centered in other directions. See GRISWOLD, FAR EASTERn Policy of THE UNITEd States (1941) cc. 5, 6. As to defense agreements, the basic nature of the Canadian-American defense arrangement of 1940 was publicly revealed. Sce N. Y. Times, Aug. 19, 1940, p. 1, col. 3, and Aug. 20, 1940, p. 1, col. 1; (1940) 3 DEP'T OF State Bull., No. 61, p. 154. No person concerned with the security of this continent could reasonably expect that the details of the military arrangements should have been publicized for the edification of the German and Japanese general staffs. Similarly, it would be unreasonable to expect that armistice or other military agreements made with regard to active war zones during the continuance of combat should be publicly disclosed.

92. There have been several occasions when secret clauses were included in treatics although only one (with the Creek Indians in 1790) has survived the Senate. See 1 MiLLER, 
secret agreements-except to the extent necessitated by war-time exigencies - are desirable, but debate in the House of Representatives can only be an additional safeguard and provide public education of the highest value.

The atrophy, finally, of two major assumptions, under which the Framers labored in creating the treaty-making procedure, conclusively removes the last possible defense of minority control. The Framers assumed, in the first place, as several times pointed out, that the Senate would participate equally with the President in the active direction of all negotiations and all aspects of foreign policy; ${ }^{33}$ under these conditions, the possibilities of conflict were greatly ameliorated. Franklin D. Roosevelt's administration made great strides towards cooperation with Congress, best evidenced by the slate of delegates to the San Francisco Conference of the United Nations. ${ }^{94}$ But no administration since the time of George Washington has been able to make the Senate a full partner; it is nothing short of fantastic to assume that the control of foreign relations could in fact be shared equally by 97 men. The Framers assumed, in the second place, that a government of national union, such as that which was in control of the executive branch in Washington's first term, would be the general rule. But under current and probable future conditions, as former Senator Gillette has pointed out, it is tempting fate a trifle overmuch to allow a minority, a third plus one of the Senate, to dominate foreign policy. ${ }^{35}$ Indeed, when the House is recognized, as it must be today, as an active participant in foreign policy, and when most important decisions must be made by the whole Congress, there is, as Madison pointed out long ago, no reason at all for requiring an additional two-thirds vote of the Senate. ${ }^{86}$

\section{The Record of Iinority Control Examined.}

In a recent article opposing amendment of the Constitution to eliminate the two-thirds rule for the approval of treaties, Professor

TREATIES, at 20. However, the proceedings of the Senate when considering treaties in esceutive session were long conducted in secrecy. See Holt, Treaties Defeated ny THE SraAte (1933) passim. The Senate rules still permit secret sessions. Senate Standing Rules, Nos. XXXV-XXXVII, SEN. Doc. No. 258, 74th Cong., 2d Sess. (1936) 39-42. These are cometimes still held. See ANDERson, op. cit. supra note 10, at 732-3. As the Framers of the Constitution recognized, the possibilities of secret treatment are obviously greatly reduced when the House joins in the process.

93. See Part I, pp. 207-S, 304. See also supra pp. 539-540.

94. Similarly, Congressmen were members of the United States delegations to the Chapultepec Conference, the Bretton Woods Monetary Conference, and the 1944 Philadelphia International Labor Organization Conference.

95. S9 CoNG. Rec. 10597 (1943).

96. 6 Writngs of James Madison (Hunt, ed., 1906) 146. 
Borchard has taken the position that "it is not possible to prove that the Senatorial check has not on the whole operated to the country's advantage." 97 Unless the people of the United States are prepared to reject democracy as a governmental philosophy, it is patent that this double-negative formulation of the issues represents an unpersuasive attempt to shift the burden of proof. In a democracy the retention of minority control over any aspect of legislation-domestic or international-would appear prima facie to be an aberration justifiable only by the presence of special factors making majority control dangerous or unwise. The burden of proof is upon the acolytes of continued minority control to demonstrate that the interests of the American people would be so adversely affected by elimination of the two-thirds rule in the making of treaties that its retention, however repugnant on grounds of principle, is pragmatically justifiable.

When we turn to the record of exercise of the Senatorial prerogative, the extraordinary burden of proof confronting defenders of the twothirds rule readily becomes apparent. Professor Borchard's argument for the retention of minority control is largely based upon a summary by Professor Dangerfield that, up to 1928, only 15 treaties had been "rejected by the Senate." 98 This figure includes, however, only those treaties which the Senate returned to the President as rejected by formal vote. ${ }^{99}$ It fails to include treaties defeated because of the failure of the Senate to take final action thereon, or even treaties which were not returned to the President after final rejection. ${ }^{100}$ Professor Danger-

97. Borchard, Against the Proposed Amendment as to the Ratification of Treaties (1944) 30 A. B. A. J. $608,609$.

98. Borchard, Executive Agreements, at 664. Professor Borchard mentions that the Senate had failed to act on many treaties, but apparently does not regard this as actual rejection. See $i d$. at 664, n. 2.

It is scarcely necessary to insist that the Senate must stamp the word "rejected" on treaties before one can conclude that it has prevented their ratification. $A$ persuasivo analogy to the Senate's veto by inaction is furnished by consideration of the dual devices available to the President for forestalling adoption of disliked legislation. Under Article I, Section 7 of the Constitution, the President may either veto bills formally or, assuming they are adopted within ten days of the close of a Congressional session, merely fail to sign them. Although the President takes no affirmative action in the latter case, it is perfectly clear that he has equally effectively prevented enactment of the legislation in question; this is well indicated by the popular description of the process as the "pocket veto." Sce ANDERSON, AMIERICAN G JVERNMENT (1938) 570-1.

99. Dangerfield, In Defense of the Senate (1933) 256.

100. Under this classification, a treaty which repeatedly fails to secure a two-thirds majority, but which is never ordered returned to the President is presumably regarded as residing in a perpetual state of immanent being. This contingency has occurred with some frequency, since under the Senate rules a majority vote is required to secure the return of a treaty to the President. The simple majority which desires to secure passage of a treaty, but is not able to do so, will often seek to deny the recalcitrant minority the satisfaction of a formal concession of defeat embodied in resubmittal to the President. See 2 Haynes, TuE SENATE of The UNited States (1938) 603-4. 
field frankly admits that, in both these latter contingencies, the "treaties were, in truth, rejected by the Senate, or at least defeated by it." 101 The technical formula by which disapprobation is affected is, of course, relevant only to file clerks; official State Department figures indicate that, up to March 1944, 104 treaties had actually been finally defeated by the Senate. ${ }^{102}$ Moreover, at least 57 treaties had been modified so seriously that they never came into effect. ${ }^{103}$

Unquestionably, the Senate's amendment of treaties negotiated by the Executive has sometimes resulted in the devisal of new agree- . ments which protected the interests of the United States more effectively than those originally submitted. Thus the amendments to the Hay-Pauncefote Treaty of 1900 , by causing deletion of the provisions precluding fortification of the canal area, permitted construction of the Panama Canal under more favorable conditions than would othervise have been possible. ${ }^{104}$ In any situation reference of an important inter-

101. DANGerfIEL. op. cil. supra note 99, at 215.

102. List prepared by Legislative Reference Service, Lihrary of Congress, in March 1944, and submitted to the House Committee on the Judiciary by Congressman Priest, Judiciary Commitlee Hearings at \&-10. The total of 104 comprises 19 treaties listed as finally rejected by the Senate, and 85 defeated by the failure of that body to talse any final action. Of the 85, all but four had been before the Senate for at least six years. Sre id. at 9.

In addition, the treaty of amity and commerce with Turkey, which failed of concent because the vote on Jan. 18, 1927 was only 50 to 34 in its favor, was withdrasn by President Roosevelt in 1934. See 2 Haynes, op. cit. supra note 100 , at 659 , n. 2; id. at 637 , n. 4. The treaties formally rejected since 1928, the date with which Professor Dangerfield's study concludes, include the St. Lawrence waterway agreement in 1933, a Nonvegian clains convention in 1940, and the Lithuanian consular treaty in the same year. See Judiciony Commitlec Hearings at 10. Dangerfield listed 47 treaties as having been defeated by Senatorial inaction up to 1928. The Legislative Reference Service lists 65 treaties as having been defeated by this pocket process up to 1929 , and 20 in the ensuing period. Sce id. at 8-9.

In general, it is the policy of the State Department-from whose public reports the Legislative Reference Service derived its material-to include in the list of treaties "on which no final action was taken by the Senate," only agreements which have reasonably definitely become obsolete because of expiration of the time prescrited for ratification in their text, or for other reasons. See Dep't of Stite, List of TrE.1TIEs Subsitted to taE. SENATE, 1789-1934 (1935) 2.

103. This figure is based on a study which goes only as far as 1932; apparently, there is no more recent inclusive study available. See DEP'T OF ST.LTE, LIST OF U:IEERFECTED TREATIEs (1932).

104. This treaty was intended to supplement the mid-nineteenth century ClaytonBulwer convention between Great Britain and the United States stipulating the conditions under which either power could construct a canal across the Isthmus of Panama. For details as to the differences between the original draft of the treaty and that negotiated and ratified after the Senate's amendments see 3 MoORE, Digest, at 211 et seq.; Foneig: ReLntions: 1901 at 245 et seg.

The action of the Senate in refusing to consent to various extradition treaties until clauses conceivably relating to political crimes were deleted also seems in ascord with the American tradition of protecting individual civil liberties. However, the evidence indicates the same modification would have been obtained if consent by majority rule had been the governing standard. See DANGERFIELD, op. cit. supra note 99, at 12S-30. 
national agreement to Congress has the undoubted advantage of stimulating public discussion of the issues involved and permits the Executive's judgment to be questioned and checked by independent critics, but these benefits can be fully realized without permitting a minority in one house to exert a final veto power.

Except as an essay in temerariousness, an attempt to pass an over-all summary judgment upon the Senate's interferences with treaties negotiated by the Executive is a bootless task requiring infinite inquiry - into unascertainable causes and choices between much disputed policies. ${ }^{105}$ Even the most cursory summary of the records permits, however, certain relevant general conclusions.

1. Limitations of the Quantitative Approach. In the first place, mere quantitative totals give a grossly inadequate picture of the significance of Senatorial interference or of the dangers of the two-thirds rule. ${ }^{100} \mathrm{~A}$ great many treaties which various national administrations had

105. But Woodrow Wilson concluded that the treaty-making clause was better described as the "treaty-marring power." Former Republican Secretary of State John Hay termed the treaty clause "the irreparable mistake of the Constitutional Convention." Both quoted in Senator Gillette's speech, 89 CoNG. REc. 3813, 3815 (1943). In 1933 Professor Holt of Johns Hopkins University concluded the most extensive study of the Senate's relation to the treaty process yet made with the following comment on the American people:

"They saw that the exercise of that power had produced such bitter conflicts between the President and the Senate and had so increased the opportunities for political warfare unconnected with the merits of the question that many treaties had been lost. They knew that the ratification of nearly every important treaty had been endangered by a constitutional system which, instead of permitting a decision solely on the merits of the question, produces impotence and friction. They realized that if no disaster had resulted it was due partly to good fortune and chiefly to the relative unimportance of foreign relations in the history of the United States so that few treaties had contained vital issues. They also realized that, if the United States was to play the part in world affairs demanded by its interests and its strength, a deadlock between the President and the Senate over a treaty involving a really critical foreign problem may end in ruin."

Holr, Treaties Defeated by the Senate (1933) 307.

106. An excellent example of the limitations of the purely quantitative approach is the article by McClendon, The Truo-Thirds Rule in Senate Action upon Treaties, 1780-1901 (1932) 26 Asr. J. INT. L. 37, cited by advocates of continued minority control as proving "the negligible part played by the two-thirds rule in the defeat of treaties." See Borchard, Executive Agreements, at 665, n. 5. To cite only the more obvious weaknesses in McClendon's article, considered as a general study of the effects of minority control: (1) no mention is made of the necessity of resorting to the Congressional-Executive agreement to annex Hawaii and Texas because of the inability to secure the requisite vote of approval for treaties, or of the use of such agreements to circumvent the two-thirds rule in the making of reciprocal trade agreements; (2) no mention is made of treaties withheld because of the probability that Senatorial consent would not be forthcoming; (3) the author limits his study to the period prior to 1901 while in the subsequent period, the two-thirds rule was responsible for the defeat of three important treaties-the Versailles Treaty of 1919, the protocol providing for American adherence to the World Court, and the St. Lawrence Waterway Treaty of 1932. 
previously negotiated or which they have desired to effect have never been submitted for approval because of the well-founded belief that Senatorial consent would not be forthcoming. ${ }^{197}$ As will be indicated in more detail below, the long shadow of minority control has been particularly potent in discouraging the use of treaties providing for arbitration of international disputes and for commercial reciprocity. ${ }^{103}$ Professor Poole has written:

"Most of the cramping effect of the present Constitutional arrangement upon our international conduct arises from mere apprehension on the part of the Executive-from the brooding sense of irrational restraint which settles upon the mind of successive Secretaries." 109

And, at another place:

". . . The record [of Senate votes] does not show from what wise measures the President or his Secretary of State has been estopped by perhaps unfounded fear of what a few senators might do, nor is it demonstrable into what brusque and harmful actions the spectre on Capitol Hill has frightened them. In the light of my own reading and my own experience in Washington, I am confident that both misfortunes have frequently befallen." 110

Furthermore, the sting has been taken out of minority control on numerous occasions because of the resourcefulness of the Executive in effectuating foreign policy through executive agreements rather than through treaties. The most famous examples, as we have indicated, are the joint resolutions authorizing the annexation of Texas and Hawaii; ${ }^{111}$ in both cases, it was believed by the Presidents malking the choice of procedure that a treaty would not receive the requisite two-thirds vote in the Senate. Similarly, although both President MIcKinley and President Theodore Roosevelt found it impossible to secure consent of two-thirds of the Senate to ratification of any of the

107. A first-hand statement of the effect of fear of the Senate in deterring trearies is contained in Secretary of State John Hay's letter to Henry Adams of Aug. 5, 1899. 3 Lctrers of John Hay and ExTracts frod DLARY (1908) 156. See also Dargerficld, op. cit. supre note 99, at 255; Poole, Cooperation Abroad Througl Organization at Hone (1931) 156 AsiNALS 136.

108. See infra, pp.558-63.

109. Poole, supra note 107, at 137. See also Flesma TaE Treaty Vero os tre AusisCAN Senate (1930) 266-8.

110. Poole, Structural Improiements in the Administration of Forcign Affairs (1933) 72 Prac. Am. PrIt. Soc. 77, 80. (The author is a former State Department official.)

111. See Part I, Section IV. The actual vote in the Senate on the joint resolution with respect to Hawaii was 42-21, but counting pairs and those not voting, a recent scholar has concluded that the "actual division of the Senate . . . mas substantially less than the two-to-one vote required to give consent to a treaty." McClurs, ExEcutrue AGrecmENTs, at 68; see 31 CoNG. REc. 6712 (1898). Clearly, President Mickinley was convinced the two-thirds approval would not be forthcoming. See Part I, p. 226. 
reciprocity treaties authorized by the Tariff Act of 1897, it was possible to consummate a substantial number of reciprocity agreements under the same act. ${ }^{112}$ The Dominican Customs Treaty of 1905 was blocked by the Democratic minority in the Senate, totaling exactly three votes more than a third of the Senate. ${ }^{113}$ Theodore Roosevelt proceeded to institute the agreement on his own authority; the Senate consented to the treaty in 1907, when three Democrats deserted the previously solid party ranks. ${ }^{114}$ On other occasions, treaties of crucial importance were adopted by the narrowest of margins, and then only after the exertion of great executive pressure. Thus the Jay-Grenville Treaty of 1795 - failure to ratify which might have eventuated in a renewal of warfare with England and which guaranteed American territorial integrity in the Northwest-was adopted by an exact 2-1 vote in the Senate, ${ }^{115}$ as was the Treaty of Paris terminating the 1898 war with Spain and ensuring American possession of Puerto Rico and the Philippine Islands. ${ }^{116}$

2. Death by Senate. In the second place, the Senate has most consistently exercised its veto powers in dealing with two important categories of agreements. ${ }^{117}$ The first category subsumes treaties for the pacific settlement of international disputes; for fifty years the Senate has interfered with the negotiation of agreements providing for arbitration of justiciable international controversies to which the United States might become a party. Cut from the same pattern, of

112. See MCCluRE, EXeCuTIVe AgreEsents, at 87-9; Holt, op. cit. supra note 105, at 195-202. It is clear that Roosevelt soon abandoned the notion of securing ratification of the eleven reciprocal trade treaties sponsored by McKinley, on the advice of Senator Aldrich and Speaker Cannon that the high protectionist clique in the Senate would block approval. See Pringle, Theodore Roosevelt (1931) 414-5; Stephenson, Nelson W. Aldricr (1930) 176-80.

113. See HoLt, op. cit. supra note 105 , at 220.

114. Id. at 228.

115. Hayden, The Senate and Treaties, 1789-1817 (1920) 83, and c. 4 generally. For a balanced statement of the crisis in Anglo-American relations existing prior to ratification of the treaty and of the concessions made by the two signatories see BEMIS, A Diplosiatic History of the American PEople (1942 ed.) 99-105.

116. See HoLt, op. cit. supra note 105, c. 8. President McKinley used the promise of patronage and other weapons to enlist the support of recalcitrant Republicans. See [Senator] Petrigrew, imperial Washington (1922) 202; 1 Lodge (ed.), Selections froa the Correspondence of Theodore Roosevelt and Henry Cabot Lodge (1925) 390. William Jennings Bryan, the Democratic presidential nominee in 1896 and 1900, used his influence with a number of Democratic and Populist Senators to induce them to vote for the treaty. PETtigRew, supra, 270-1; 2 [Senator George] Honr, Autobiograpiry of SEventy Years (1903) 322-3; Hibben, The Peerless Leader: William Jennings Bryan (1929) 222.

117. See Fleming, The Role of the Senate in Treaty Making: A Survey of Four Decades (1934) 28 Aar. Pol. Sci. Rev. 583, at 596, n. 9; see also Dangerfield, Treaties Defeated BX THE SeNATE (1933) passim. 
course, was the action of the Senate in refusing to consent to American membership in the League of Nations. The second major exercise of the veto power has been with respect to agreements for tariff reduction; two-thirds of the reciprocal trade treaties referred to the Senate have failed of passage. ${ }^{118}$

The appraisal any observer puts upon the Senate's conduct depends, of course, upon his judgment as to the type of foreign policy the United States should pursue. Professor Fleming has summarized the issues succinctly:

"To those who believe that a policy of national isolation can and should be maintained, the record of the Senate is not disturbing; it is highly praiseworthy. To others who are convinced that a progressively developing machine civilization requires strong and effective international controls, the negations of the Senate are much more destructive than conservative." 119

At this moment of impending decision, it is instructive to examine in some detail the procedures by which the Senate and the minority veto power have contributed to maintaining "a policy of national isolation." The narration may appropriately begin in the $1890 \mathrm{~s}^{153}$ Previously the United States had taken the lead in the promotion of the arbitration of international disputes. ${ }^{121}$ Since 1794 there had been a consistent acquiescence by the Senate in the power of the Executive to submit international disputes to arbitral tribunals, set up pursuant to treaties, without securing the consent of the Senate to each specific reference. ${ }^{122}$ In addition, many claims against foreign governments had been submitted to arbitration by direct Presidential agreement. ${ }^{123}$

118. Fleming, loc. cit. suppa note 117; see also Flesing, The Treaty l'eto of the Auserican Senate (1930) 72-5; LaUghin and Willis, Reciprocity (1903) 9, 75-85.

119. Fleming, The Role of the Senate in Treaty Making: A Surrey of Four Decades (1934) 28 Arr. Pol. SCI. REv. 583.

120. The action of the Senate in connection with arbitration treaties is discussed in varying detail in Fleming, supra note 119, at 584-5, 587-9; Fuemmo, Tue Untred States atid THE WORLd COURT (1945) 20-3; cc. 3-S; Moore, Fifty Years of Intcrialtonal Lawo (1937) 50 HARv. I. REV. 395, 408-12; HolT, op. cil. supra note 105, at 153-62, 204-12, 230-5; Daigerfield, op. cit. supra note 99, at 175, 185-9, 215-9, 260-6; Flexing, TaE Treitr Veto of THE Alierican SENATE (1930) cc. 5, 9, 10.

121. See HolT, op. cit. supra note 105, at 154-5; Afoore, supra note 120; Dangersfeld, op. cit. supra note 99 , at 260.

122. Thus under Article VII of the Jay Treaty with England of 1794, a large variety of claims of British and American citizens against the governments of the two countries had been referred to arbitration. The terms of the various submissions were set by the diplomatic officers of the two governments. Similarly, under the Anglo-American treaty of Feliruary 1853, "all claims" of citizens of either country against the government of the other arising subsequent to the Treaty' of Ghent terminating the War of 1 S12 were referred to a mised commission. See Moore, supra note 120, at 409.

123. See Part I, Section IV. Perhaps the most important example was the SpanichAmerican Claims Commission set up by exchange of notes in 1871. See Moore, supira note 
Apparently desirous of effectuating this "leading feature of our foreign policy," ${ }^{24}$ the Senate and the House adopted a resolution in 1890 urging the negotiation of general arbitration treaties. ${ }^{126}$ In 1897, partly because of the necessity for hastily improvising arbitral machinery during the recently terminated dispute over the Venezuelan border, the Democratic President Cleveland negotiated a treaty with Great Britain providing for arbitration of territorial and pecuniary controversies. ${ }^{126}$ In submitting the treaty to the Senate, President Cleveland declared:

"The example set and the lesson furnished by the successful operation of this treaty are sure to be felt and taken to heart sooner or later by the other nations, and will mark the beginning of a new epoch in civilization." 127

Two months later, the next President, the Republican William McKinley, in his inaugural address called for "the early action of the Senate thereon, not merely as a matter of policy, but as a duty to mankind." ${ }^{128}$ The Senate first proceeded to add a series of exclusionary clauses to the treaty and then voted "that no arbitration should proceed until the compromis, the detailed agreement whereby every special arbitral tribunal is set up, should have been approved by two-thirds of the Senate." ${ }^{129}$ Finally, after sixteen amendments had been adopted and in the face of apparently overwhelming popular support, ${ }^{130}$ the arbitration treaty failed-of adoption since it merely received a vote of 43 yeas to 26 nays. ${ }^{131}$

Writing immediately after amendments completely changing the substance of the proposed treaty had been followed by rejection by minority veto-a rejection which forestalled the possibilities of negotiating similar arbitration treaties with other nations ${ }^{132}$-former Secretary of State Olney attributed the defeat of the treaty primarily to the determination of a few Senators to protect their personal prerogatives at all costs and to show "to the world the greatness of the Sen-

120, at 408-9. As pointed out in Part $I$, there is no difference in principle between submission by executive agreement of claims against, and claims in favor of, the United States.

124. The description is quoted from President McKinley's inaugural address in 1897.

125. 21 CoNG. Rec. 2986 (1890); 7 MOORE, Digest, at 74.

126. The proposed treaty and some of the preceding correspondence are reprinted in FoREIGN RELATIONS: 1896 at 222-40.

127. 9 Richardson, Messages, at 747.

128. See note 124 supra.

129. Fleming, The Role of the Senate in Trealy Making: A Survey of Four Decades (1934) 28 Asr. PoL. Scr. Rev. 583, 584.

130. See Holt, Treaties Defeated by the Senate (1933) 156-7; Blake, The OlncyPauncefole Treaty of 1897 (1945) 50 Asr. Hrst. Rev. 228, 237. Blake's article is the most complete history of the negotiation of the treaty and of the controversy in the Senate.

131. 31 SEN. EXEc. J. 104 (1897).

132. See 7 MOORE, Digest, at 78. 
ate." ${ }^{133}$ More dangerously premonitory of things to come was Olney's remark, addressed to the procedure whereby the proposed treaty had first been rendered devoid of purpose by amendments accepted by majority vote, that the agreement was "done to its death not by open enemies but by professed friends." 134

In ensuing years, this pattern was repeated, with minor variations. Within five years of the Hague Conference of 1899, thirty-three arbitration treaties were signed by the nations of the world. Reluctant to see the United States abandon its traditional policy, Secretary of State John Hay drafted treaties with five governments, basically modeled on the Anglo-French agreement of October 14, 1903, but containing a series of exclusionary clauses alin to those the Senate had insisted upon seven years before. ${ }^{135}$ In the event that the first treaties were approved, it was the intention of the administration to negotiate with other governments. ${ }^{136}$ These "brave, new hopes" never came to fruition. The Senate proceeded to amend the terms of the proposed treaties to require that every proposal for an arbitral reference would have to be submitted for its consideration; otherwise phrased, the Senate agreed to agree to arbitrate, whenever it decided to do so.15i This retrogression from a genuine arbitral agreement into pious doubletalk impelled President Theodore Roosevelt to refuse to attempt renegotiation of the treaties as amended by the Senate: ". . . we had better abandon the whole business rather than give the impression of trickiness and insincerity which would be produced by solemnly promulgating a sham." 135

Subsequent national administrations found it possible to secure consent to the ratification of general arbitration treaties only by retaining the clause that the terms of each reference would have to be approved in advance by the Senate. ${ }^{153}$ Even President Taft's mild proposal, apparently strongly backed by public opinion, ${ }^{169}$ to establish Joint High Commission's of Inquiry, convenable at the request of either party, which were to be empowered to send matters on for

133. Quoted in Holt, op. cit. supra note 130, at 159. The excerpt is taken from a letter written to Henry White, with the request that it be shown to officers of the British govornment. Id. at 158. See also id. at 156-62; Blake, supra note 130, at 240-2; Low, The O!igarchy of the Senate (1902) 171 No. Ass. Rev. 231.

131. Quoted in HoLT, op. cit. supra note 130, at 160.

135. Fleming, The Treaty Veto of the Americany Sexiate (1930) 86.

136. 2 JoHNSON, AMERICA's FoREIGN RELATIONS (1916) 361-6.

137. Compare Theodore Roosevelt's letter to Senator Lodge, 2 LodGE, op. cil. sufpra note 116 , at 110,111 ; Moore, sispra note 120 , at 40 S-9.

138. 2 LODGE, op. cit. suspra note 116, at 111.

139. This was true of the Root treaties of $1908-1909$ and the Kellogs Treaties of $1928-$ 1929. See FleuIng, op. cit. sispra note 135, at S9-90, 112-5.

140. See Fleming, The Treaty Veto of the Aurericas Senate (1930) 92. Sce also the Senatorial admissions of the popularity of the treaties. 4 S CokG. Rec. 1835, 2593, 2865, 2944 (1912): 2 LODGE, op. cit. supra note 116, at 419. 
arbitration only upon the consent of two of the three American members and provided Senate approval was obtained, was modified into meaninglessness; ${ }^{\mathbf{1 4 1}}$ the President thereupon abandoned these treaties too. ${ }^{142}$ Thus was frustrated at its inception President Taft's plan for securing adoption of treaties between the United States and the other major powers, and, following this example, between the majority of the European states, so that cooling-off periods could be provided to help turn the resolution of future conflicts into peaceful channels. ${ }^{143}$ Professor John Bassett Moore has summarized the situation in the following pungent language: "The result is that, so far as the United States is concerned, it is in practice now more difficult to secure international arbitration than it was in the early days of our independence." 144

Less subject to criticism is the Senate's record in dealing with treaties referring specific disputes to arbitration. In the case of the CanadianAmerican fisheries dispute, however, the Senate by a strictly partisan vote defeated in 1888 a treaty negotiated by a Democratic administration providing for, what is now and was then generally described as, a fair compromise of the conflicting claims. ${ }^{145}$ An attempt to secure settlement of this dispute by a treaty negotiated in Theodore Roose-

141. See Fleming, op. cit. supra note 140, at 98 . These amendments were added by a largely partisan vote, with the majority composed of 36 of the 39 Democrats voting, and only six of the 43 Republicans. See Holt, op. cit. supra note 105, at 234. The majority report of the Senate Foreign Relations Committee had declared that the treaties, as negotiated, were unconstitutional, since only the Senate could determine whether a dispute was arbitrable. See Fleming, supra, at 93. This contention in effect concluded that almost every President since and including George Washington had acted unconstitutionally, since almost all had referred disputes to arbitration or diplomatic settlement on their own initiative.

For a persuasive statement of the value of this type of arbitral agreement and of the flaws in the arguments of the Foreign Relations Committee see Taft, The Dawn of World Peace, Woman's Home Companion, November 1911.

142. Fleming, op. cit. supra note 140 , at 101 .

143. Professor Borchard has recently sought to dismiss these treaties defeated or amended to death as unimportant, because they were "abstract agreements." Borchard, The Two. Thirds Rule as to Trealies: A Change Opposed (1945) 3 Econ. Council. Parers, No. 8, p. 8. It is curious that Presidents Cleveland, McKinley, Theodore Roosevelt, Taft, Wilson, and Coolidge and their respective Secretaries of State should have put themselves to so mutch effort on a matter of no importance. See also Moore, supra note 120.

By the same logic, any agreement providing for arbitration or mediation of disputes between employer and union, or parties to a contract, could be dismissed as trivial since prior to the actual emergence of controversies, the problem is "abstract." But the very function of a general arbitral agreement is to provide machinery whereby settlement of future controversies may be expedited and the parties accustomed to peaceful negotiation.

144. Moore, The Princirles of American Diplomacy (1918) 331.

145. See Dangerfield, In Defense of the Senate (1933) 242-4; Fleming, op. cit. supra note 140, at 68-72; BaILEy, Diplomatic History, at 439; Holt, op. cit. supra noto 105, at 144 et seq. As to the vote in the Senate see 26 SEN. ExEc. J. 333 (1888); DunNing, The British Eurpire and the United States (1914) 280.

One of the Republican Senators commented on the opposition to the treaty succinctly, 
velt's administration was delayed in the Senate for two years, and then amended to the point where the President declined to resubmit it to the British. ${ }^{146}$ Theodore Roosevelt attributed the death of the treaty to the pressure exerted by the fishermen of Gloucester, Massachusetts, acting through Senator Lodge. ${ }^{147}$ It was not until 1909 that it was possible to adopt a treaty providing for arbitration of the controversy. ${ }^{148}$ The Treaty of 1912, based on the arbitrator's award, embodied provisions not substantially dissimilar from those rejected twenty-four years before.

3. Versailles and After. It is common knowledge that a Senate minority turned again to obstructionist tactics to thwart the vill of a Congressional and popular majority in dealing death to the Treaty of Versailles. Professor Borchard has recently sought not only to condone this action but to clothe it with the public interest by insisting that "the Treaty deserved defeat because it was not a treaty of peace but a declaration of war," and by suggesting that "even at the time, informed students realized that it was likely to prove a charter for the production of conflict and war." ${ }^{143}$

For our present purposes, the merits or demerits of every particular section of the much maligned peace agreements of 1919 are irrelevant. It is interesting, however, to contrast with Professor Borchard's hyperbolic animadversions the recent careful summary of President Seymour:

"As we look back at [the Versailles Treaty], with the advantage of twenty-five years' perspective, it is clear that most of the diatribes against the injustice and unwisdom of that treaty and the others which formed the settlement of 1919 have small foundation in fact; on the contrary, the treaties created ample opportunity to accomplish recovery in the economic sense and maintain peace in the political, if only those who followed had been able to capitalize it." 150

\footnotetext{
"We cannot allow the Democrats to take credit for settling eo important a dispute." Quoted in Shippee, Thomas Francis Bayard in 8 Bexrs, Arrericix Secretarres of State (1928) 45, 63.

146. See Holt, Treaties Defe.jted by the Sen.ite (1933) 199-201.

147. 2 Lodge, Selections frost the Correspondence of Theodore Roosevtht ard HENRY CABOT Lodge (1925) at 175.

148. During the interregnum, a "mere" executive agreement regulated the rights of the parties. This agreement-kept in force by five Presidents-is another interesting commentary on Professor Borchard's contention (Evceutice Agrecments, at 678), refuted in Part I, Section VI, that executive agreements are "uneafe," since subject to free termination by any successor of the President initially responsible for them.

149. See Borchard, Esecutize A greements, at 665 . Note the interesting list of authorities cited in support of this interpretation by Professor Borchard. Ici. at 665, n. 4 .

150. Seymour, Versailles in Perspectice (1943) 19 VA. Q. REv. $4 \$ 1,483$.
} 
Similarly, another recent authoritative study, Professor Birdsall's Versailles Twenty Years After, concludes that the Treaty constituted "a realistic concession to French needs without violating the Fourteen Points in any important particular." 151 Since without some concessions agreement between the Allies would have been impossible, Professor Borchard-unless he is to retire into the scholar's traditional ivory tower-must be either urging that a completely Carthaginian peace would have been preferable ${ }^{152}$ or else lending his approval to the American defection which by precipitating the "Anglo-French duel ... reduced Europe to the chaos from which Hitler emerged to produce new chaos . . . ."153

The crucial problem in 1919 and 1920 was, as it is now, that of inaugurating a world security organization with the United States as an active participant. It is, of course, impossible to reweave the threads of history and tell how different the history of the 1920s and the 1930s would have been if the United States had signed the Treaty and joined the League. To quote Professor Birdsall again :'

"It is vitally important to distinguish between the treaty as a written constitution and as a policy in action. Students of constitutional law have long since learned to distinguish between the intentions of founding fathers, as expressed in the verbal niceties of a constitutional document on the one hand, and the practical application of organic law to a constantly changing society on the other hand. Students of international politics, more particularly students of international law, have on the whole been less discriminating. The history of the Treaty of Versailles would have been very different if the United States had ratified it, since the treaty itself was largely shaped on the assumption that it would have behind it both the authority of the United States and the impartial influence of the United States as a constantly moderating influence in its enforcement." 154

What is important today is the method by which the United States' adherence to world organization was prevented. Professor Borchard

151. Birdsall, Versailles Twenty Years After (1941) 296. See also AlbrechtCarril, Versailles Twenty Years After (1940) 55 PoL. Scr. Q. 1, 23, concluding that, if the Treaty caused "certain grievances, on the other hand it redressed greater ones; this is especially true of the territorial settlements." The same view is taken by Professor Hoffman of Fordham University. Hoffaran, Durable Peace (1944) 5. See also Fraser, Germany BETWEeN Two WARS (1945) c. 3.

152. Both Theodore Roosevelt and Henry Cabot Lodge-two of the irreconcilable foes of the Treaty of Versailles-urged dismemberment of Germany and imposition of crushing reparations. See Nevins, HeNry White: THIRTY YeArs of AMERICAN Diplonacy (1930) 252-3, 360; Tusidury, Woodrow Wilson As I KNEw Him (1921) 340; Scirriftgiesser, The Gentlemian from Massachusetts: Henry Cabot Lodge (1944) 293, 302-3.

153. BIRDSALL, op. cit. supra note 151, at 297. For detailed discussion see Wolfers, Great Britain aNd France BetweEn Two Wars (1939).

154. BIRDSALL, op. cit. supra note 151, at 296-7. 
maintains that "The real cause of the Treaty's defeat was that President Wilson requested Democratic Senators not to accept the Lodge reservations." 155 The assumptions in this suggestion about historical causation in general and about this specific event need no detailed comment. It would be just about as realistic to attempt to describe a bull-fight and to leave out either the bulls or the picadors and the matadors. Today one can say in retrospect that President Wilson probably erred in advising his friends among the Democratic Senators in 1920 to vote against ratification of the Treaty, even crippled as it was by the Lodge reservations. But, at the very least, a coordinate factor in defeating the Treaty was the part played by Senator Henry Cabot Lodge, some of his partisan colleagues, and a small coterie of irreconcilable Senators of both parties, determined upon enforcing an isolationist policy upon the United States. 10 The tactics used by these groups have great significance today both as a general indication of the dangers attendant upon the two-thirds rule and as a warning to those engaged in making the present peace agreements.

Until the very last moment, President Wilson and his supporters made efforts to come to a compromise with opponents of the Treaty. Thus the revised draft of the Covenant of the League prepared by Wilson in April 1919, after his trip to the United States, embodied almost all of the concrete proposals for change previously made by the Republican leaders-Elihu Root, Charles Evans Hughes, William Howard Taft, and Senator Lodge himself. ${ }^{157}$ But this was unavailing. As Lodge himself had told his political confidents his aim was to defeat the Covenant, in the face of its support by $80 \%$ of the American people, by devising a continuous series of reservations, "but to throw on the President the onus of its rejection." Irs

The tactic used by Senator Lodge was to continue to devise a series of amendments to the Covenant and the Treaty. Under the Senate rules a majority vote is all that is needed to amend a treaty. Thus Lodge was able to secure adoption of these amendments by a majority composed of (a) irreconcilable opponents of the Treaty seeling to destroy its attractiveness to advocates of international cooperation, (b) political foes of Wilson, and (c) whatever members of the admitted majority favoring the Treaty could be lured into supporting any particular reservation, in the vain idealistic hope that some foes of the

155. Borchard, Executire Agreements, at 665 ; see also Borchard, suspra note 143 , at 4.

156. There is evidence that Lodge basically sympathized with the League, but opposed the Covenant for partisan reasons. See Professor Bailey's report of an interview with Senator Borah in 1937. Balley, Diplosiatic History, at 669. See also 2 Jessup, Eliue Roor (1938) 403-3; speech by Lodge in 1916, quoted in Berdahl, Tie Lraderslisp of the Urited States in the Postarar World (1914) 38 Ass. Por. Scr. Rev. 235, 236; Nevnis, op. cit. stspre note 152 , at 451 .

157. See Schriftgiesser, op. cit. supra note 152, at 325.

158. Quoted in Howland (ed.), Asrerican Foreign Relations: (1928) 272. 
Treaty could eventually be conciliated. These hopes were frustrated, as the minority, to quote Republican Senator Nelson, continued to grope "around to find objections to defeat the Treaty." ${ }^{169}$ On Lodge's methods we have first-hand testimony of one of his colleagues, Senator Watson of Indiana:

"We had not been in the contest ten days before Senator Lodge called'me over the telephone and asked me to take dinner with him that evening. . . . At that Sunday evening dinner he said to me that; while Senator Curtis was the regular whip and would have charge of all matters pertaining to the ordinary routine of legislation, yet he wanted me as his special representative to have charge of the organization in the Senate in the League of Nations fight. He asked me to keep 'mum' on this assignment and to report to nobody but him, to which I readily agreed. My service having been largely in the House up to that time, I had never had to deal with a treaty concerning which there was any conflict and knew little or nothing of the procedure in such cases. 'Senator,' I said to him, 'I don't see how we are ever going to defeat this proposition. It appears to me that eighty percent of the people are for it. Fully that percentage of the preachers are right now advocating it, churches are very largely favoring it, all the people who have been burdened and oppressed by this awful tragedy of war and who imagine this opens a way to world peace are for it, and I don't see how it is possible to defeat it.'

"He turned to me and said: 'Ah, my dear James, I do not propose to try to beat it by direct frontal attack, but by the indirect method of reservations.'

" 'What do you mean by that?' I asked. 'Illustrate it to me.'

"He then went on to explain how, for instance, we would demand a reservation on the subject of submitting to our government the assumption of a mandate over Armenia, or any other foreign country. 'We can debate that for days and hold up the dangers that it will involve and the responsibilities we will assume if we pursue that course, and we can thoroughly satisfy the country that that would be a most abhorrent policy for us to adopt. . . .'

"Senator Lodge then went on for two hours to explain other reservations and went into the details of situations that would be thus evolved, until I became thoroughly satisfied that the treaty could be beaten in that way. . . ."160

The last attempt to work out a compromise on Lodge's reservations was thwarted when Lodge and his colleague Senator New turned

159. 58 Cong. Rec. 3404 (1919).

160. Watson, As I KNEw ThEM (1936) 190-1; see also ScHRIFTGIESSER, op. cit. supra note 152, at 335, 366; Darling, Who Kept the United States Out of the League of Nations? (1929) 10 Can. Hist. REv. 196. 
recalcitrant and backtracked on the previously tentatively accepted agreement. ${ }^{161}$

The tragic dénouement was that the desires of an overwhelming majority of the American people, ${ }^{162}$ as even the opponents of the Treaty admitted, were frustrated by the adroit tactics of the minority. Even the irreconcilable Senator Moses of New Hampshire afterwards admitted that, but for the delays permitted under the Senate rules and carefully taken advantage of, "the Versailles Treaty would have been ratiffed without reservations." 103 No one has ever denied that a substantial majority of the Senate wished to see the Treaty adopted. Yet, just as in the case of previous agreements providing for international cooperation, the minority was able to prevail because the two-thirds rule prevented devisal of an acceptable compromise. ${ }^{164}$

Concurrently with the drafting of the Treaty of Versailles, a treaty had been negotiated whereby the United States and Great Britain bound themselves to come immediately to the aid of France in the event of an unprovoked aggression by Germany. It was in reliance on this treaty that the French abandoned their most extreme demands in the Treaty of Versailles. ${ }^{165}$ President Wilson submitted the treaty to the Senate in July 1919, but it was never reported from the Committee on Foreign Relations. ${ }^{166}$ Clearly the inability to secure a two-thirds vote in favor of the League Covenant or the Treaty of Versailles rendered futile any hope of securing this type of majority for the guaranty treaty. The significance of this Senate-enforced withdrawal from participation in preventing a recrudescence of German militarism 107 is indicated by Sumner Welles' recent testimony that the outbreak of the war in 1939 might have been averted if there had been assurance of United States intervention. ${ }^{169}$

The issues of international cooperation were next joined in a signifcant manner in connection with the question of American membership in the World Court. The Republican successors of Wilson, Presidents Coolidge and Harding and Secretary of State Hughes, urged that the United States should adhere to the Court. The platforms of both

161. Darling, supra note 160 , at 200-6, 208.

162. See Watson, loc. cit. supra note 160; Lodge, The Senate aro tue Leaguc of Natroxs (1925) 147. Senator Harding told Senator Borah: "Bill, I'd like to get in the fight against this League of Nations, but the people of my state are all for it, I'm afraid." Jon:SON, BORAB OF IDAHO (1936) 232-3.

163. Quoted in BAILEY, DiploMatic History, at 670.

164. See supra pp. 560-3.

165. See BIRDSALl, op. cit. sappra note 151, at 297; Boxsal, UNrr:isued Busness (1944) 188. Bonsal's book was awarded the 1944 Pulitzer prize in the field of American history.

166. See N.Y. Times, Feb. 14, 1945, p. 18, col. S.

167. See Vandenberg, supra note 86 , at 17 ; LIPPAIANN, op. cil. sutpra note 82 , cc. G-7.

168. See Welles, The TnIE For Decision (1944) 77, 119. 
parties in the 1924 election contained provisions in favor of joining the Court. On March 3, 1925, the House of Representatives adopted a resolution recommending adherence by a vote of 303 to $28 .{ }^{100} \mathrm{But}$, when the issue came before the Senate in 1926, it was impossible to secure the requisite two-thirds vote, except by including five reservations. All proved acceptable to the other members of the Court, except the fifth which in effect precluded the Court from giving any advisory opinion on any subject as to which the United States had or claimed an interest, without its consent. ${ }^{170} \mathrm{~A}$ constructive commentary on the validity of this super-cautious reservation-and the view of certain Senators that their prerogatives were matters of world importanceis furnished by the fact that not a single other nation found it necessary to request a similar reservation. ${ }^{171}$ No wit daunted by this record, strenuous efforts were made under the sponsorship of Presidents Coolidge and Hoover to devise a formula which without unduly insulting the rest of the world could secure the approval of two-thirds of the Senate. A series of compromise reservations were thereupon drafted by the distinguished elder statesman Elihu Root. However, when the question of adherence came before the Senate again, this time under the sponsorship of President Roosevelt, it failed of adoption on January 29,1935 , since the majority of 52 yeas to 36 nays was short of the necessary two-thirds. ${ }^{172}$

It cannot be denied, of course, that an international tribunal-while of great assistance in preventing the accumulation of unsettled grievances between nations, leading to increasing tension and resentment, and accustoming the public to peaceful settlement of international disputes-is not by itself capable of averting wars. However, the Senatorial debate on the World Court, as everyone knew, actually involved the basic dispute over American cooperation to further world peace. To the world at large the refusal of the Senate minority to permit adherence by the United States to the World Court was evidence that the United States, while doubtless disapproving of war, could be relied upon not to take any significant steps toward intergovernmental cooperation to prevent large-scale aggressions. ${ }^{173}$

169. For the general background see BaIlEy, Diplosaric History, at 710; FLEMING, The United States AND TaE WORLd COURT (1945).

170. For the text of the reservations see Hudson, THE Wortd COURT 1921-1938 (1938) $248-9$.

171. See Fleming, The Role of the Senate in Trealy Making: A Survey of Four Decades (1939) 28 AM. Pol. Scr. Rev. 583, at 587-9.

172. Professor Bailey has recently concluded that American public opinion was distinctly favorable to adherence to the World Court. BaIlEY, Diptossatic History, at 717. However, a last minute propaganda campaign initiated by William Randolph Hearst and Father Coughlin, which brought a flood of telegrams, resulted in a defection of enough members previously intending to vote for adherence to the Court to prevent obtainance of the two-thirds vote.

173. It should also be noted that on Jan. 19, 1932, after delaying action for threo years, 


\section{The Merits of Treaties and How Minnority Contro! Operates.}

"I do not think so meanly of any of my colleagues in this budy as to believe that they would be actuated by any such despicable motives, but I cannot close my eyes to the records of our national history."

\section{Senator Gillette of Iowa, Decemter 13, 1943.174}

It has been urged, with repetitiveness suggesting seriousness, that "a treaty should be convincing enough to command a two-third vote" 175 and that "the necessity of obtaining a two-thirds rote assures a good treaty rather than the hasty or emotional consideration which a bare majority might reflect." ${ }^{176}$ Wholly apart from its departure from basic democratic principles, it may be noted that this suggestion proceeds on the assumption that the individual members of the Senate in dealing with foreign policy are entirely governed by honest convictions as to the long-term best interests of the whole United States, and are in no significant degree motivated by political or party considerations, fear of local pressure groups, or antipathy to the incumbent Executive. There is no need to exaggerate the extent to which Senators, like other people, may respond to treaties from considerations other than their merits, but, as former Senator Gillette has recently pointed out, "the records of our national history" unfortunately furnish too much reason to believe that small groups "motivated by partisan antagonisms, political prejudices, or personal antagonism and illwill against an Executive" can, if minority control continues, thwart "all the efforts of our executive department and the will and wish of two-thirds of this body, less one." 177 There are, in addition, a number of peculiarities in the organization of the Senate that facilitate the task of a minority in stalemating the majority.

"Politics stops at the water front" is an appealing slogan, but acquaintance with the diplomatic history of the United States, as Professor Haynes has said, provides "little justification" for the belief that "treaty-making will be handled as a non-partisan matter." lis Indeed,

the Senate vitiated the general treaty of inter-American arbitration by adding recervations providing that no agreement involving the United States could be submitted until the particular compromis had been approved by two-thirds vote of the Senate, and that in any case no controversies which arose under preevisting treaties could be submittcd for arhitration. See Fleming, supra note 171 , at 590 .

174. S9 CoNG. REC. 10597 (1943).

175. See Borchard, Erecutire Agreements, at 667.

176. See Borchard, The Two-Thirds Rale as to Trealies: A Clange Opposed (1043) 3 Econ. Council Papers, No. S, p. 5. See also Borchard, Bools Review (1914) 4 Lawrens GUID REv. 59.

177. 89 Cong. Rec. 10597 (1943).

178. 2 Haynes, The Senate of the United States (1938) 630; see also Senator John - Sharp Williams' comments, 62 CoNG. Rec. 3855 (1922):

"If a Republican President had sent the Versailles Treaty" to this body, three- 
before the end of George Washington's tenure of office, the sanguine expectation of the Framers that debate on foreign policy would be conducted on a non-partisan basis had been thoroughly dispelled. The voting on Jay's treaty with England in 1795 was conducted on a strictly party basis. ${ }^{179}$ The 1824 treaty with Great Britain for suppression of the slave trade was amended to death in the Senate, in large measure because of the opposition of Senators hostile to Secretary of State John Quincy Adams, the heir presumptive to the Presidency. ${ }^{180}$ We have already referred to the unusual concatenation of political motives which defeated the 1844 treaty for the annexation of Texas. ${ }^{181}$

The theme of partisan opposition to treaties, although by no means invariably present, has recurred in more recent years with disconcerting frequency. As previously explained the almost unanimous opposition of the Democratic minority-which prevented a two-thirds majority - forced Theodore Roosevelt to initiate the Santo Domingo

fourths of you on the Republican side would have voted for it, including the Senator from Massachusetts (Mr. Lodge). And if Mr. Wilson had sent these treaties lthe Washington Conference Treaties] to this body, two-thirds of you Democrats would have voted for it, including the Senator from Nebraska (Mr. Hitchcock) and the Senator from Montana (Mr. Walsh). . . . is it not about time ve stopped our partisanship at the coast line?"

In 1943, Senator Gillette said:

"The historical evidence . . . certainly should convince us that our Chief Executives have been given much cause for being sceptical and reluctant in the matter of laying international pacts before the Senate for ratification as treaties."

89 Cong. Rec. 10600 (1943); see also 1 Bryce, The American Comalonwenlth (rev, ed. 1913) 122. The best generalized sources of information are the discussions of the fate of particular agreements in Holt, Treaties Defeated by the Senate (1933); Fleming, Tite Treaty Veto of The AMrerican Senate (1930); and Dangerfield, op. cit. supra note 145.

179. Those who were to emerge the following year as the Federalists supported the treaty throughout; the Anti-Federalists were in opposition. See HaYdEN, THE SENATE AND TrEatIes, 1789-1817 (1920) c. 4, especially at 83; HolT, op. cit. supra note 178, at 17-18.

180. Senator Van Buren of New York, an opponent of Adams and of the treaty and a future President of the United States, regarded the Senate's amendments as a means of defeating the treaty. VAN BUREN, Autobiograpry (1920) 203. John C. Callhoun and the British charge Addington were only two of the many contemporary observers who also re. garded political considerations as the principal reason for the opposition to the original treaty. See 6 Memoirs of JoHN Quincy Adass (C. F. Adams, ed., 1875) 338-9, 348-50; HoLT, op. cit. supra note 178, at 48-9. It has since been asserted that the principal reason for opposition was the fact that the treaty proposed to give British vessels the reciprocal right to search American ships off the American coast to take off slaves. But the House of Representatives, after receipt of a report stating that a mutual right of search was indis. pensable to stop the slave trade [H. R. REP. No. 92, 17th Cong., 1st Sess. (1882) ], had adopted a resolution the previous year by a vote of 131 to 9 urging the President to negotiate treaties with the European powers for suppression of the slave trade. 40 ANNALs of CoNGRESS, 1147-55 (1823). The Senate amendments contained the absurd proposal that American vessels be permitted to search British ships in the West Indies for slaves, but that the British have no reciprocal right as to American vessels. Fleming, op. cil. supta note 178 , at 55 .

181. See Part I, Section IV, pp. 263-4. 
customs receivership in 1905 by direct Presidential agreement. ${ }^{132}$ Perhaps the most convincing single piece of testimony as to the importance of partisanship is furnished by the speeches of former President Taft during the 1920 Presidential campaign. On the grounds that, even if in supporting the Democratic aspirant the country unmistakably indicated its support for the League, Republican "senatorial recalcitrance" was not likely to abate, Taft urged that the only way to ensure the United States' entrance into the League of Nations was to elect Harding, the Republican candidate. ${ }^{183}$ A substantial number of the Democratic Senators assumed a comparable attitude of intransigence in 1922 in dealing with the treaties signed at the MYashington Conference. ${ }^{184}$

Extrinsic considerations other than partisan politics have also been important. On too many occasions, personal antipathy-sometimes based, to quote former Senator Gillette again, on "resentments which found their genesis in campaign contentions, patronage distribution, or equally unworthy situations" 185 - have been conjoined with, or have operated apart from, partisan considerations in creating opposition to treaties. It is perhaps ungracious to do more than refer in a footnote to a few situations where such factors have been important, although clearly on occasion they have played havoc with our foreign policy.1:3 Former Secretary of State Richard Olney once attributed a substantial amount of Senate opposition to or alteration of treaties to the simple desire "of humiliating the executive and of showing to the world the

182. See Holr, op. cit. supra note 178, at 215-22. In 1905, the Democratic party caucus adopted a resolution providing that "if two-thirds of this caucus shall vote in favor of the foregoing resolution [against consent to the proposed treaty] it shall be the duty of every Democratic Senator to vote against the ratification of the eaid treaty." 40 Co:iG. REC. 2054 (1906).

183. Rogers, The Auerrcan Senate (1926) 77-8. It should be noted that Taft advocated ratification of the Treaty. For further commentary on the partican nature of a portion of the opposition to ratification of the Treaty of Versailles cee Holt, Bool: Review (1945) 50 Axr. HIST. Rev. 361 el seq.

The contention that the results of the 1920 election demonstrate the opposition of the American public to the Leagure, which, as previously indicated, is contrany to the contemporaneous impression of its Senatorial opponents, is further refuted by the fact that a large group of distinguished Republicans tool the position that the merits of the League and World Court were not at issue during the campaign. Harding's own public statements were equivocal in the extreme. See Flesing, The United States and tre Wondo Coura (1945) 34-5.

181. See the criticism by John Sharp Williams, Democratic Senator from Miscissigpi, in 62 CoNG. Rec. 3855-6 (1922), quoted in part in note 178 stspro.

185. 89 CONG. REC. 10597 (1913).

186. See, e.g., 2 Joenson, AMrerici's FoneIGN ReL.itions (1916) 78; remarlis of Sanator Stephens of Mississippi, 67 CoNG. REc. 2799-801 (1926); Senator Copeland's view: as to the reasons for opposition to the Isle of Pines Treaty, D.xigerfircn, op. cit. sutpra note 145,

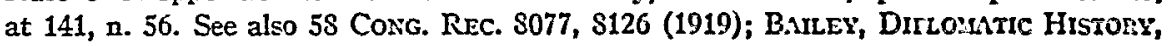
at 669 . 
greatness of the Senate." 187 Other experienced statesmen such as Theodore Roosevelt and John Hay have on occasion made similar. comments. ${ }^{183}$ This type of motivation has been particularly present in the case of general arbitration treaties. ${ }^{189}$ As Professor Fleming has pointed out, the insistence upon personal prerogative is particularly dangerous in the case of multilateral agreements, which by their very nature must be compromises between the view of nations with divergent interests and political heritages. ${ }^{190}$ Here the attempt to insist that the agreement, to quote Olney's phrase, bear the "Senate brand" 191 can only result in precluding effective cooperation by the United States in international organization.

It is also known that, on a number of occasions not always involving matters of minor importance, a "microscopic" group of Senators has been able to block a treaty to protect some parochial interest. This seems, for example, to have been the case with the Isle of Pines Treaty, ratification of which was delayed from 1903 to 1924, and the Canadian fisheries treaty of $1905 .{ }^{192}$

The way has been simplified for minority control to achieve these results by a number of the features of the Senate's ordinary procedure. Perhaps the most important is the amendment to the Senate rules adopted in 1868, providing that treaties could be amended by majority vote. ${ }^{193}$ The perverse uses to which this can be put, when coupled with a two-thirds rule for final approval, have been well described by Professor Holt:

"The effect of this change was to increase still further the power of those opposing a treaty, for under it amendments could be in-

187. Quoted from his letter to the American minister in London, with reference to tho Senate action on the 1897 arbitration treaty. Holt, op. cit. supra note 178, at 159-60.

188. See Theodore Roosevelt's views as to the reasons for alteration of the 1904-05 arbitration treaties, HoLT, op. cit. supra note 178, at 207; John Hay's statements, quoted in 2 HAYNEs, op. cit. supra note 178, at 657, and in 2 Thayer, LIFE AND LETTERs of JoIn HAx (1915) 392-3; Grover Cleveland's views, Rogers, The American Senate (1926), at 250-1.

189. With reference to the 1904-05 arbitration treaties, Senator Orville Platt, a Connecticut Republican, commented: "But it does not do the Senate or the country any good to be continually looking to see if in some unimportant particular the Executive has not gone too far. I have known people so jealous of their own rights, and so fearful of interference therewith that they made their whole lives miserable, forfeiting the respect of everyone who knew them. I feel that the Senate is acting like such individuals." Coounde, YAN Old-Faseroned Senator, Orville H. Platt (1910) 481.

190. Fleding, The Role of the Senate in Treaty Making: A Survey of Four Decades (1934) 28 AM. POL. SCI. REV. 583, 596.

191. HoLT, op. cit. supra note 178 , at 159.

192. See Dangerfield, In Defense of the Senate (1933) 135-43; Holt, op. cit. supra note 178, at 199-201. Even President Theodore Roosevelt attributed the defeat of the fisheries treaty to "Gloucester's attitude." Ilid.

193. Rule XXXVII, par. 1, reprinted in SEN. Doc. No. 258, 74th Cong., 2d Sess. (1936) 42. 
serted or reservations added by an ordinary majority vote. A small group of senators wishing to defeat a treaty, but not numerous enough to do so, could henceforth achieve their purpose by an indirect method. By joining with others, who favored the treaty only with changes, they could force amendments which would make the treaty unacceptable to some who had favored it in its original form. These new opponents, added to the few who had opposed the treaty in any form but who helped to male the changes in it, might constitute more than one-third of the Senate. Thus the treaty would be defeated. This was exactly the method used in defeating the Versailles treaty in 1919." 104

The powers of the minority have also been assisted by the ability of a small group of Senators to conduct long-drawn out filibusters; ${ }^{205}$ even those who favor a particular treaty may be loathe to vote for closure in order to retain the right to block by the sheer volume of their oratory other measures they dislike. Likewise, particularly in the case of treaties of less urgency, the undefinable but pervasive doctrine of "senatorial courtesy" 196 has permitted a small coterie to dominate the entire body.

No one would be so naive as to assert that all danger of the frustration of international undertakings by such extraneous factors as the desire to promote party interests or personal antipathy to a particular President is eliminated when domestic validation is sought by majority vote of both houses of the Congress. Such problems are ineradicable from the activities of man. It should be obvious, however, that there is less chance that opposition based purely or primarily on political motives-which relatively infrequently enlists all members of the party opposed to an incumbent President-can be successful when the 'two-thirds rule is not applicable. ${ }^{197}$

194. Holt, op. cit. supra note 17S, at 120. See also Anderson, Auserichi: Governizenit (1938) 783.

195. See DANGERFIELd, op. cit. supra note 192, at 140-1. The most successful filituster in connection with foreign affairs was the action of eleven Senators in March 1917, preventing a vote on the Armed Ship Bill. See RoGErs, op. cit. supra note 18s, at 176-7. However, closure was applied in the debate on the covenant of the League of Nations in 1919 and the vote on adherence to the World Court in 1935.

196. See Fleaing, The Treaty Veto of the Aurencan Se:sate (1930) 287.

197. Two recent comments by Professor Borchard are interesting. "It is stated," he writes, "in some quarters that majority control by House and Senate means in fact Esceutive control, since the President can exert patronage and other pressures on a bare majority if necessary. The two-thirds rule places the Senate in an independent position beyond pre:dential control even if his Party should command a bare majority." Borchard, stffric note 176 , at 5 . He adds, "Majority control might possibly be considered if this nere a parliamentary government, in which the Administration could be removed if it incurred the displeasure of the people. The proposed Amendment includes no such proviso, and is therefore inadequate." Id. at 6.

One can only wonder why this does not apply equally to domestic afiairs and be amazed at the general distrust of our democratic, legislative way. There seems to be no recognition 
The Non-Democracy of the Two-Thirds Rule and Some Irrelevant Analogies.

"When any number of men have ... consented to make one community or government . . . the majority have a right to act and conclude the rest."

JoHN LOCKE. ${ }^{193}$

It is improbable that any responsible citizen would be so callous in 1945 as to deny that, as an abstract proposition, majority rule is "the central axiom" of democracy. ${ }^{199}$ In etymology and by long tradition, democracy "means government by the people"; in lieu of breaking heads, counting heads is the most practical way yet discovered for securing compromise of conflicting views and desires. ${ }^{200}$ That each is "to count for one and nobody for more than one" ${ }^{201}$ is, likewise, an indispensable rule in such counting, if minorities are not ultimately to rule majorities and whole peoples. "The first principle of republicanism," wrote Thomas Jefferson, is "to consider the will of the society announced by the majority of a single vote, as sacred as if unanimous." This, he continued, "is the first of all lessons in importance, yet the last which is thoroughly learned." 202

While a democratic constitution, such as our own, must embody full protection of personal liberties and civil rights, ${ }^{203}$ there is nothing in the broadest reach of these guaranties - as the whole history of our Congress's legislation with respect to "domestic" affairs demonstratesthat precludes a representative assembly of the people from making its decisions by majority vote, ${ }^{204}$ or that requires that a minority be

by Professor Borchard that a rule which makes the view of a minority third plus one prevail, when views conflict as to foreign policy, gives that minority the positive power to shape the nation's foreign policy. Inaction may on occasion have stronger effects than action.

198. Quoted in Kendall, John Locke AND the Doctrine or Majority RuLE (1941) 112.

199. BARKer, REFLections on GovernMent (1942) 69.

200. Id. at 35. See also Penniman, Thomas Paine-Democrat (1943) 27 AM. Pol. Scr. Rev. 244, 252.

201. Jeremy Bentham, quoted in [former Congressman] T. V. SMrti, TuE Promise of AMERICAN Politics (1936) 53.

"Perhaps no convention of our day is more acceptable to both the political scientist and the man on the street than the employment of the simple-majority device to determine the will of a group." Heinberg, Hislory of the Majority Principle (1926) 20 Am. PoL. Scr. Rev. 52.

202. Quoted by Mims, The Majority of the People (1941) frontispiece. See also Jefferson's First Inaugural Address, 1 RiCHARDSON, MESSAGES, at 321, 323.

203. Note the exaggerated fears of Senator Willis as to what might happen if the onethird veto were abolished. (1944) 10 Town MeEting Bullerin, No. 28, p. 7.

204. "So long as the American republic was preoccupied with guaranteeing essential functional freedoms like freedom of speech, freedom of the press, freedom of association, freedom of the ballot, the minority found adequate guarantees for its natural rights in the principle of majority rule itself. To the extent that the individual and the minority were free at all times to engage in all legitimate activities by way of building up a new majority, 
allowed to frustrate the achievement of majority will, after fair debate, in matters affecting the economic welfare and physical safety of the nation. ${ }^{205}$ Indeed, the principle of majority rule is something more than an article of democratic faith, fully consistent with civil liberties; it embodies in fact the only practical procedure by which a representative system of government, which must act, can act effectively. ${ }^{206}$ For the existence of a minority veto power must mean ultimately either that the government is rendered impotent or that the majority is forced to acquiesce in the will of the minority. No verbal evasion can obscure the fact that one of the two groups, either the majority or the minority, must have its way."37 "There could be but one of two rules adopted in all governments," commented Mr. Justice Story, "either that the majority should govern or the minority should govern." 208 The pivotal objection, therefore, to requiring that international agreements made by the United States must be approved by two-thirds of the Senate is, as Senator Fulbright has observed, that such a requirement gives "too much power to too few men." $\mathrm{s}: 3$

The full extent to which the principle of majority rule has been embodied in the Government of the United States has recently been the subject of authoritative summary:

"All of the provisions of the Constitution were adopted by majority vote in the convention, and the Constitution itself was ratified by majority vote in the State conventions.

"The Constitution contemplates that Congress may enact laws by majority vote; that the President and Vice President may be elected by majority vote; that the Supreme Court and inferior courts may render judgment by majority vote; that a majority of the States represented in the House may elect a President when the

there was no inherent conflict between the principle of majority rule, proparly enforced, and the principle of minority rights. To the extent that the power of the majority was restrained by the very principle of majority rule from tampering with these fundamental political prerogatives of the minority, both the majority and the minority found ample accommodations in the democratic process." Miss, op. cit. supra note 202, at 13.

205. "The Virginians were ransacking the dictionary for adjectives in support of the proposition that constituent power resides at all times in the hands of a majority of the living community.

"To this extent George Mason and James Wilson and John Quincy Adams vere expounding a theory of popular sovereignty with which Rousseau would have found himself in substantial agreement-a theory of sovereignty which declares that in the last resort the only limitation on the power of the existing majority is the principle of majority rule itralf, as guaranteeing the eternal right of the individual and the minority to work openly at all times toward the formation of a new majority." MInss, op. cit. suspra note 202, at 33.

206. A useful distinction between democratic philosophy and procedure is develoned in KENDALL, op. cit. supra note 198.

207. Id. at 21.

208. 1 Story, Commentaries on the Constitution (5th ed. 1891) 651.

209. (1941) 10 Town MientiNg BuLLetiN, No. 25, p. 7 . 
electors fail; that Congress may annul treaties by majority vote; that Congress by majority vote may permit a State to make a compact with a foreign power; that in case of a vacancy in the office of President and Vice President the Congress may by majority vote name the acting President; that the Senate by majority vote may approve or reject all nominations to Federal office; and that the House by majority vote may impeach any person holding Federal office." 210

The obvious question is why, if all of these important governmental acts have required or require only a simple majority, should the legislative approval of international agreements be distinguished, by requiring an exceptional majority of two-thirds? Clearly it is impossible, as has been pointed out above in the discussion of sectional interests, to state any over-all distinction in terms of importance ${ }^{211}$ between the matters dealt with in the domestic and international activities of the Federal Government, if indeed it is still possible in 1945 to distinguish the ramifications of "domestic" and "international" problems. Legislation directed primarily to internal affairs and governmental activity directed primarily to international affairs may have the same immediate effects upon the daily life of the people of the nation. The most important single aspect of our foreign policy, the power to declare war, is in all cases confided to the majority of Congress, in collaboration with the President. Indeed, as pointed out in Section III of this article, the powers of the Congress to enact legislation-with respect to tariffs, immigration, maritime affairs, and so on-are broad enough, certainly when supplemented by the independent powers of the President, to cover regulation of all important aspects of our relations with other peoples and governments. The question may still be asked, by what principle of democracy is it necessary to superimpose upon this regulation a veto by a minority third of the Senate whenever, and only whenever, the full implementation of the policy of the Congress requires the negotiation of an intergovernmental agreement?

The arguments of the proponents of minority control fall generally into two categories. The first theme-presented with Spenglerian over-

210. Bloom, The Treaty-Making Power (1944) 17.

211. The more important a governmental act is, the more necessary it would appear, in a democratic state, to subject it to majority rather than minority control. Compare former Assistant Secretary of State Berle's statement of the reason for putting the proposed St. Lawrence agreement in the form of a Congressional-Executive agreement rather than of a treaty: "I propose to close this phase of the subject by saying that it did seem that in an issue of this size and of this importance, it was hardly fair to place in the hands of the minority of one house the ultimate decision on a measure of very great importance to the entire country. For that reason the agreement form was selected, and it is in that form that it is here." Hearings before the Committee of the House on Rivers and Harbors on the Improvement of the Great Lakes-St. Lawrence Seaway and Power Project, 77th Cong., 1st Sess. (1941) pt. 1, p. 45 . 
tones-is that the majority cannot be trusted to control foreign policy and must be saved from itself. Professor Harry Elmer Barnes has summarized this attitude in the bathetic language that ". . . the Senate's treaty power [i.e., the two-thirds rule] is probably the last remaining bulwark of our national safety-even more, perhaps, than our armed forces-and it should be fought for and maintained at all costs." ${ }^{212}$ Besides approving this statement, ${ }^{213}$ Professor Borchard has added a more explicit declaration of distrust in democratic control:

"This talk of leadership of the United States is an extremely deceptive way of losing our lives. We're among the most naive people in the world in foreign affairs. We don't understand foreign affairs, and to trust the leadership to people who do not understand is exceedingly dangerous." ${ }^{214}$

If Professor Borchard is right in his assertion that the American people "don't understand foreign affairs," this unwisdom presumably permeates the whole nation to an equal extent. It is somewhat difficult to see why a Senator who casts a negative rote should $a$ priori be considered twice as intelligent and be given twice as much influence as one who casts an affirmative vote. ${ }^{215}$ The defense of the two-thirds ruleon grounds beyond prerogative-must reduce itself ultimately to an assertion that a chosen minority knows better "than the majority of the American people what is good for us." 210 The argument has been made since the Middle Ages that the will of the wiser rather than the more numerous should prevail,, ${ }^{217}$ but until we are furnished with the

212. Barnes, Book Review, The Progressive, March 20, 1941, p. 10, col. 2.

213. See Borchard, Esecutire Agreements, at 683; Borchard, Bools Reviev (1944) 4 LAWYERS GUILD REV. 59, 61-2.

214. (1914) 10 Town Meeting Bulletin, No. 25, p. 16. Contrast Senator Fulbright's remarks in the same debate.

215. Thus, see Professor Borchard's admission and retraction later in the rame debate:

"Man: The question is for Professor Borchard. Is it assumed that the majority

of the elected Senators and Representatives are not qualified to ratify a treaty? "Dr. Borchard: No, it's not assumed that they're not qualified. They are, But it isn't in the Constitution now, and there are very' good reasons why the Constitution shouldn't be changed." Id. at 18 .

The only reason stated for retention of the two-thirds rule is the need for protection of the small states (id. at 21), a shopworn slogan, which is not only, as has been shorn above entirely irrelevant, but which was never even raised in this context at the Constitutional Convention.

216. Remarks of Senator Fulbright, id. at 6. Senator Fulbright is, of course, heaping scorn upon the notion.

217. See Barker, op. cit. supra note 199, at 65.

"By what criterion are we to measure the value of any particular sill of a majoriry? . . . Who is the final judge, superior to the decision of the majority, who will apply the criterion of value to its will? If, when the judge is found and the criterion applicd, the will of the majority is discovered to possess less value, and the vill of the minority greater, must the will of the minority prevail? To asl these two questions is to realize at once that the 
formula for the selection of the elite, we are entitled to doubt that the minority has any unique monopoly of wisdom. Government by a selfdesignated elite-like that of benevolent despotism or of Plato's philosopher kings-may be a good form of government for some peoples, but it is not the American way. ${ }^{218}$ Certainly the historical record of minority veto power, epitomized in the preceding Sections, indicates that the two-thirds rule is "the last remaining bulwark" of nothing more sacred than the politics of obstructionism and of an isolationist foreign policy.

The second theme, no less ingenious, is that a minority veto in the Senate is more likely to produce a result in accord with popular opinion than a majority vote in both houses. Thus, Professor Herbert Wright in a recent article, while declaring his allegiance to Senator Pepper's contention ${ }^{219}$ that the vote on treaties (or any form of international agreements) "should be as broadly representative of the popular will as the machinery of our government can make it," concludes:

"But this desideratum is more apt to be attained under the twothirds vote of the Senate than under a simple majority of both houses of the Congress. It might be an easy matter for a party to muster an ordinary majority vote for a measure, although the majority of the people of the United States might be opposed to such measure. In the case of ordinary legislation, there is a remedy for such flaunting of the public will at the polls every two years, but no such remedy is available in the case of treaties with other nations. On the other hand, it would be extremely difficult to secure a two-thirds vote of the Senate on a treaty, unless that twothirds vote represented at least a majority of the people." 220

It scarcely needs emphasis that this argument is nothing more nor less than an attack on the general doctrine of majority rule and on the principles of representative government; for if "a party" can "muster an ordinary majority vote" for an international agreement, although a majority of the people are opposed to the measure, the same result can obtain in the case of domestic legislation. Unless we are prepared to

importation of the idea of quality, over and above the idea of quantity, and as something separate from the idea of quantity, may involve the destruction of the majority principle, and, pro tanto, the negation of democracy. To enthrone a super-judge who may in turn enthrone a minority is to abandon democratic institutions." Id. at 66 .

218. In reply to those who besought him to use his influence to block ratification of the admittedly majority-supported treaty of Paris in 1899, William Jennings Bryan said: "If people are against us minority of Senate cannot save us. [Telegram, Jan. 11, 1899.] . . . wo ought not to succeed unless we do have the people with us." [Letter, Jan. 13, 1899.] Quoted in Holt, Treaties Defeated by the Senate (1933) 177, n. 33.

219. Compare Pepper, A Stummons Against the "Kiss of Death," N. Y. Times Magazine, Dec. 12, 1943, p. 5, col. 1 .

220. Wright, The Two-Thirds Vote of the Senate in Trealy-Making (1944) 38 AM. J. INT. L. 643, 644-5. 
initiate government by continuous referendum, it is impossible to avoid the contingency that the Congressional division on any particular measure may be different from that in the country as a whole. But this is no valid reason for retaining a reto power in a minority of one house of Congress. The chances are certainly something more than even that the majority in both houses will more nearly reflect the views of the majority of the whole country. There is no evidence whatever for an inference that the majority in both houses is less likely to be "broadly representative of the popular will" than is one-third plus one of Senate, or any other Congressional minority. ${ }^{221}$ In 1935, to talke a specific example, the Senate failed to approve adherence to the World Court by a vote of 52 ayes to 36 noes, after the House had recommended adherence by 302 to 26 . It may at least be questioned whether the two-thirds rule here subserved "the popular will." 222

One may wonder, further, why the remedy for possible "flaunting of the popular will" is any less available in the case of an act of Congress authorizing an international agreement, than in the case of any other statute. The members of Congress continue to stand for re-election, even after authorizing or sanctioning international agreements. Moreover, since there are on the whole fewer important international agreements than domestic statutes, it is reasonable to assume that the people when they go to the polls may more closely bear in mind the attitudes of their Congressmen upon such agreements. If, moreover, direct response to the popular will is the agreed desideratum, it seems difficult to justify or to prefer a process of approving international agreements which excludes the House of Representatives, the agency of the Government which meets the test of the polls most often. ${ }^{223}$

For a minor variation on these unpersuasive themes there is the "extraordinary situation" argument. Thus, Professor Borchard writes that "The argument for 'democracy' is equally invalid" because "All constitutions require for important acts a decisive majority;" 224 and Professor Herbert Wright insists that "it is true that, in general, a

221. Some of the critics of the minority veto have pushed statistics to the extent of suggesting that it is mathematically possible for 17 Senators representing $S \%$ of the population to block ratification of a treaty. The assumptions underlying the mathematice-that a minimum quorum of 49 is present, which however, includes the Senators from all the smallest states, all of whom vote against the treaty-are obviously a little strained. Nevertheles, it is true, as Senator Fulbright remarked, that "a small group of men, representing relatively few people, can nullify the efforts of the majority to create by treaty a more stable and peaceful international order." (1944) 10 Town MieErng BuLLET:, No. 25, p. 5.

222. For arguments that it would be democratic, as well as constitutional, for the United States to join the Permanent Court by joint resolution of both houses, see Mlathews, The Joint Resolution Mrethod (1938) 32 Aus. J. INT. L. 349; Garner, Aels and Join! Reselutions of Congress as Substitutes for Treaties (1935) 29 id. at 482.

223. Compare the recent report of the House of Representatives Committce on the Judiciary on H. J. Res. 320, H. R. Rep. No. 2061, 7Sth Cong., 2d Sess. (1944).

224. Borchard, Executize Agreenents, at 671. 
majority vote is requisite for democratic rule, but this does not preclude the settlement of extraordinary matters of a fundamental nature by more than a majority vote." ${ }_{225}$ Professor Borchard elaborates: "Impeachment requires two-thirds of the Senate, and ratification of constitutional Amendments, three-quarters of the states. We hang capital offenders only by a unanimous vote of a jury." 220 More recently he has written that "A treaty is something quite different from a statute. A treaty binds the nation and cannot be changed by an act of legislation. A statute can be. ... A treaty is the practical equivalent of a constitutional Amendment." 227

The relevant question about these alleged analogies is, admitting that democratic government may have some procedures that require a vote of more than one-half plus one, whether or not the policy which is thought to require an exceptional majority with respect to each of these analogies applies also to the authorizing or sanctioning of international agreements. On the face of things, it is not a little strange that these particular analogies should be thought to be more relevant than all of the other governmental acts, listed above, which taken together permit the over-all summary that "operation of the Government by majority vote is the general rule of the Constitution." 228 Professor Borchard's "numerous acts" requiring a two-thirds vote total four. Two-conviction by the Senate of an impeached federal officer ${ }^{229}$ and the expulsion of members-are patently quasi-criminal proceedings, where the general presumption requiring guilt to be proved beyond a reasonable doubt prevails. These examples are relevant to the instant problem only on the assumption that there is a presumption, as strong as the presumption of innocence, against making international agreements and in favor of inaction. ${ }^{230}$ It would appear that the fact today is the exact opposite. ${ }^{231}$ The other two examples-the passage of

225. Wright, supra note 220 , at 644 .

226. Borchard, Executive Agreements, at 671. The irreverent may wonder why, on grounds of comparable policy, it is not added that in most secret fraternities two blackballs prevent election.

227. Borchard, The Two-Thirds Rule as to Trealies: A Change Opposed (1945) 3 Econ. Counct Papens, No. 8, p. 6. See also Borchard, Against the Proposed Amendment as to the Ratification of Treaties (1944) 30 A. B. A. J. 608, 609.

228. BLooss, op. cil. supra note 210, at 17.

229. However, the House may impeach a federal officer by majority vote. U. S. CoNsT. Art. I, § 2 .

230. The examples might also be relevant on the assumption that there is some mys* terious affinity between the ratification of treaties and criminal law.

231. It may bear further emphasis that a negative, minority vote rejecting an international agreement establishes a foreign policy for the United States with effects just as positive and observable, however different, as an affirmative, majority vote approving an agreement. In every case a choice must be made between alternative policies and the choico may be just as irreversible, in terms of its effects on the United States, when an agreement is rejected as when it is approved. The real question of who shall have the power to decide, 
legislation over a Presidential veto and the removal of political disabilities imposed by conviction in the federal courts-deal with conflicts between Congress and the coordinate branches of the Government. But the process of making an international agreement involves cooperation with a coordinate branch, the Executive. Professor Borchard's bland statement that a treaty "cannot be changed by an act of legislation" is refuted by the half-score or more Supreme Court decisions holding that the status of a treaty as "the law of the land" is terminated by adoption of a joint resolution of denunciation or even inclusion of inconsistent provisions in a later statute. ${ }^{232}$ One is at some loss to comprehend the meaning of the climactic statement that a treaty has "the force of an Amendment." ${ }^{233}$ There are a number of decisions holding that treaties may be enforced only when they comply with the provisions and limitations of the Constitution. ${ }^{334}$ The Supreme Court has never held that the treaty-making power includes the power to change any of the traditional guaranties of the Constitution, and there are compelling reasons why it should not so hold. It seems safe to conclude, therefore, that the treaty-maling power is subject to exactly the same restrictions in this respect as the power of Congress to enact legislation. If a treaty is "the practical equivalent of a constitutional Amendment," so also is erery statute ever enacted.

As a final argument in defense of the two-thirds rule, Professor Borchard asserts that "In all constitutions of which I am aware, important decisions must be made by two-thirds or greater majority." 235

the minority or the majority, cannot be concealed behind vague allueions to "well considered" action. One may with equal relevance demand that the inaction propored by a minority be "well considered" before it is imposed upon the majority. In there days of continuous communication, public consideration of public issues procceds at a rapid pace, and, under contemporary world conditions, too long a pause to enable a minority to attemnit to persuade the majority may result in total paralysis.

232. See Part I, Section VI, for further development and citation of the relevant decisions.

233. Borchard, The Two-Tlirds Rule as to Treaties: A Clange Opposcd (1915) 3 Ecor. COUNCII PAPERs, No. 8, p.7.

231. See Part I, pp. 281-6. Since the decision in United States v. Darby Lumber Co., 312 U.S. 100 (1911), it has been clear that the doctrine of MIissouri v. Holland, 252 U.S. 416 (1918), that the power to make treaties was not limited by the Tenth Amendment applies equally to the power of Congress to make statutes. It also seems clear that the Fifth Amcndment is as much a limitation on the treaty-making as on the legislative power-that is, that treaties containing provisions in contravention of the Amendment could not be enforesd in the courts. See cases cited Part I, Section VI.

235. Borchard, The Two-Thirds Rule as lo Trcaties: $A$ Clange Opposed (1945) 3 Ecor. Council PAPERs, No. 8, p. 9.

Professor Borchard also cites to support the desirability of a two-thirds rule in the Senate the fact that it is proposed that the General Assembly of the United Nations Sccurity Organization act on important matters by two-thirds vote. We should have suppossd that after 156 years of national unity, the mutuality of interests and degrce of understanding between the states of the United States were somewhat closer than now frovails between, 
In the context, it might be supposed that this statement bears some relation to the process by which other nations ratify treaties. Reference to an authoritative source indicates that in only two nations has it been deemed necessary to require more than a majority vote for treaty-making-Liberia and Guatemala. ${ }^{236} \mathrm{We}$ assume that in the making of international agreements, as in other aspects of statesmanship, the United States wishes to be more and not less democratic than other governments.

\section{Interchangeable Procedures and Patterns of Post-War ORGANIZATION}

"If we are to measure up to the task of peace with the same stature as we have measured up to the task of war, we must see that the institutions of peace rest firmly on the solid foundations of international political and economic cooperation. The cornerstone for international political cooperation is the Dumbarton Oaks proposal for a permanent United Nations. International political relations will be friendly and constructive, however, only if solutions are found to the difficult economic problems we face today. The cornerstone for international economic cooperation is the Bretton Woods, proposal for an international monetary fund and an international bank for reconstruction and development."

\section{President Roosevelt's Message to Congress of February 12, 1945}

During the first World War, the statesmen of the Allied powers refrained from proposing plans for the prevention of future conflicts until after the cessation of hostilities. Moreover, the Versailles peacemakers have been criticized because of the extent of their preoccupation with political problems and their relative lack of concern with the problem of reviving world trade on a stable basis and promoting closer international economic integration. ${ }^{1}$ Both errors are being avoided by the statesmen of the United Nations. While our armies are still locked in battle on a dozen far-flung fronts, the operational blueprints for a general security organization - the so-called United Nations Charterand for a series of agencies to deal with specific economic problems of a transitional or a long-run nature have already been drafted or pro-

say, Ethiopia and Colombia, or China and the United States. It is somewhat surprising that we are not also referred to the Senate of the former Kifigdom of Poland, where every individual member possessed an absolute veto on all proposed action.

236. Guatemala requires consent of two-thirds of each house (WILCOx, RATIFICATION OF INTERNATIONAL CONVENTIONS (1935) 87-8), and Liberia of two-thirds of the Senate (id. at 89-90).

1. See Keynes, Economic Consequences of the Peace (1920); Straigut, Make This tae Last War (1943) 294, 295; Salter, Allied Shipping Control (1921) 220-1. 
jected. It is as yet too early to tell what specific form many of these emergent instrumentalities of international cooperation will take. But few doubt that the people of the United States want their government to participate actively in the affairs of these agencies, just as it is already participating in some twenty-five international organizations, ${ }^{2}$ in addition to the many war-time United Nations organizations.

From the standpoint of constitutional power, it is clear that the United States may signify its adherence to such organizations by either treaty or Congressional-Executive agreement. The convention establishing an international organization is fundamentally nothing more than an agreement between a large number of States to cooperate in promoting commonly-desired ends. The number of signatories to an agreement has, of course, no effect upon the constitutional mode by which validation may be secured under the Constitution of the United States. In point of fact, as has already been pointed out, the executive agreement has almost always been the instrument utilized for effecting the United States' adherence to international organizations. ${ }^{3}$ This procedure was the basis by which this government joined the International Labor Organization, the Pan-American Union, the Universal Postal Union, the recently organized United Nations Relief and Rehabilitations Administration, and many other similar groups. In at least one case, that of the International Labor Organization, the President negotiated an agreement of adherence, pursuant to authorization embodied in a joint resolution, after a treaty had failed of adoption. ${ }^{4}$

It is equally clear that, beyond the question of mere formal entry into an organization, the United States may approre the substantive provisions - delineating functions, granting powers, prescribing responsibilities, outlining procedures, establishing legal capacity, and so onof the various organizations now being proposed and may commit itself to observe the terms of these agreements by either treaty or Congressional-Executive agreement, and in some instances also by direct Presidential agreement. All of the proposals thus far made are both appropriate subjects for international negotiation and are easily within the scope of the combined powers of the Congress and the President. This may be demonstrated by brief reference to the two most important and comprehensive sets of agreements, the Bretton Woods monetary agreements and the proposed security agreements.

2. See Schueckebier, International Organizitions mi Which the Uitted States Participates (1935).

3. See Part I, Section IV.

4. See Part I, pp. 270-1. 
The Bretton Woods Monetary Agreements-An Essay in International Economic Cooperation.

The interdependence of the economic objectives of the United States and of the other United Nations is rapidly becoming a matter of common knowledge. ${ }^{5}$ In his message asking Congressional approval of the Bretton Woods agreements, the late President Roosevelt gave realistic emphasis to this critical fact:

"What we need and what they need correspond-expanded production, employment, exchange, and consumption-in other words, more goods produced, more jobs, more trade, and a higher standard of living for us all. To the people of the United States this means real peacetime employment for those . . . returning from the war and for those at home whose wartime work has ended. It also means orders and profits to our industries and fair prices to our farmers. We shall need prosperous markets in the world to insure our own prosperity, and we shall need the goods the world can sell us. For all these purposes, as well as for a peace that will endure, we need the partnership of the United Nations." 0

Since the first common problem confronting the United Nations is that of providing assistance in giving relief and facilitating rehabilitation in war-devastated areas, it was appropriate that the first of the new international economic organizations to be set on a going basis was the United Nations Relief and Rehabilitation Administration. The variety and importance of the other problems which in an increasingly interdependent planetary economy require joint action is indicated by a mere listing of a number of the already projected or contemplated organizations in this field: the provisional Civil Aeronautics Council, ${ }^{7}$ the United Nations Food and Agriculture Organization, agencies to promote orderly marketing of raw materials and commodities, and-multi-national shipping, radio, petroleum, and wire communications councils. ${ }^{8}$

5. See, e.g., Hansen, America's Role in the World Economy (1945); Rostow, American Security and Foreign Economic Policy (1945) 34 Yale Rev. 495; Brown, TuE Future Economic Policy of the United States (1943) pt. 3; Staley, World Economy IN TRANSITION (1939).

6. International Monetary Fund, Message from the President of the United States, Transmitting Recommendation for the Passage of Legislation Dealing with the Subscription of the United States to the International Monetary Fund, and Our Membership in Such Futhd, H. R. Doc. No. 70, 79th Cong., 1st Sess. (1945) 2.

Bills approving American adherence to the Fund and Bank have been introduced in both houses of Congress. See H. R. 2211 and S. 540, 79th Cong., 1st Sess. (1945). H. R. 2211 was recently approved by an overwhelming majority.

7. International Conference on Civil Aviation, Final Act (1945). For a brief description see Van Zandt, The Chicago Civil Aviation Conference (1945) 20 Foreign Pourcy REPORTS 290, 294-5.

8. See generally Message from the President, cited supra note 6, at 4-5; N. Y. Times, Jan. 5, 1945, p. 1, col. 3 . 
However, the linchpins of the program for international economic cooperation are the interrelated agreements for establishment of the International Monetary Fund and the International Bank for Reconstruction and Development.9 Since the last war the flow of goods from country to country has been hampered by the pursuit of autarchic financial policies and a race of competitive monetary depreciation, predicated on what has been characterized as the "beggar my neighbor" school of economics. The International Monetary Fund seels to "promote stability of exchange rates without running the risks involved in a rigid fixity of rates." 10 It provides machinery whereby the initial post-war structure of currency ratios may be established by consultation between the powers and whereby rates may be adjusted when necessary because of fundamental disequilibrium. By promoting stability of the exchanges and requiring regular consultation about monetary policies it will result in increasing the flow of useful trade across national boundaries. From the standpoint of the United States, this charter of international monetary peace presages an expansion in export trade. ${ }^{11}$

The aim of the International Bank for Reconstruction and Development is to promote the reconstruction of devastated areas and assist in the industrialization and development of the resources of backward areas. Essentially, the Bank will be a mutual insurance and guarantee agency, facilitating lending by existing private and public agencies, but where necessary making loans itself. ${ }^{12}$ At the same time as the Bank thus aids in the achievement of higher standards of living in devastated or retarded areas, it will stimulate employment in the capital-exporting countries such as the United States. ${ }^{13}$

9. See International Monetary Fund and Interiational Banis for RiconStRUCTION AND Developirent (U. S. Treas. Dept. 1944); for a convenient summary şe Bretton Woods IIonetary Conference-Plans and Achiccentents (1944) 20 Foreig:: Pouscy REPORTS 138. See also HANSEN, op. cit. supra note 5, cc. 2,4; Rostow, stupra, note5, at494, 513.

10. See HANSEN, op. cit. supra note 5, at 49-50.

11. See generally Brown, The INTERNational Gold StaNdard (1940); Aorgenthau, Bretton Woods and International Cooperation (1945) 23 Fonsign Arfans 132; White, The Monetary Fund: Some Criticisms Examined (1915) 23 FoneIgr AFFuns 195; Hutrser, op. cit. supra note 5, cc. 4-8.

12. There is an instructive analogy between the proposed Bank's functions and taclis in stimulating international commerce and the functions and tools used by the Fational Housing Administration and the Reconstruction Finance Corporation in stimulating private residential construction and domestic trade generally. See Haxsen, op. cil. stspre note 5, at 35 .

13. See Hansen, op. cit. supta note 5, cc 4-5; Staley, World Econounc Develop3ENT (1944); CONDLIFFe, AgENDA FOR a POST-WAR WORLd (1942) c. 8. The common assertion that by promoting industrialization of now baclsward arazs, the Unitcd States would frustrate its own industries is completely refuted by an examination of trade figures. In the immediate pre-war years, the United States' chief customers were Great Britain and Canada, both great industrial nations. (Our trade with Germany and Japan was curtail by political considerations.) In Europe, the largest volume of trade tools place between the 
Even most of those financial groups which are critical of specific details of the Fund are united in agreeing as to the necessity of establishing a Development Bank and of establishing some sort of international monetary agency, to prevent stagnation of world trade and a revival of the chaotic financial conditions of the 1930s. ${ }^{14}$ The merits of the specific agreements are not, of course, relevant to the question of constitutional power, but the fact that the agreements as actually drawn at Bretton Woods represent the consensus of opinion of leading experts of 44 nations, without whose cooperation financial stability is a delusive dream, suggests that they are well designed - and perhaps the only agreements obtainable-to implement appropriate national purposes.

Under the clear constitutional mandates and the well-established precedents described in the earlier Sections of this article, it is plain that the United States may join the Bretton Woods-or any other similar international financial organizations-through either a treaty or a Congressional-Executive agreement. No one questions that the subject matters of the Bretton Woods agreements are appropriate for international negotiation, and the specific powers of Congress with respect to these subject matters stem directly from Article I, Section 8 of the Constitution, which provides in part that:

"Congress shall have power ... to coin money, regulate the value thereof, and of foreign coin, and fix the standard of weights and measures ... to borrow money on the credit of the United States ... to regulate commerce with foreign nations."

1. The Monetary Power. An intricate network of intermeshing legislation has been built upon the monetary and currency powers of Congress. ${ }^{15}$ It has long been recognized that Congress's monetary powers subsumed control over the relations between domestic and

most heavily industrialized States. In fact, the industrialization of a nation has always tended to expand its imports. See Staley, supra, c. 8; LeaGue of Nations, Eurore's TRADE (1941) passim, especially p. 49 and table 4, p. 16; LEAGUE of NATIONS, TUE NETWORK OF WORLD TRADE (1942) passim, especially p. 19.

14. See Williams, International Monetary Plans After Bretlon Woods (1944) 23 FoREIGN AfFaIrs 38; Viner, Two Plans for International Monetary Stabilization (1943) 33 YALE REv. 77; Amierican Bankers Ass'n, Practical International Financial Organization throvgh Aarendments to Bretton Woods Proposals (1945); New York State Bankers Ass'N, Bretton Woods Proposals (1945). A special subcommittee of the Committee for Economic Development recently recommended Congressional approval of the Fund and Bank, with one minor modification of the Articles of Agreement. See N. Y. Times, March 20, 1945, p. 1. See also Steiner, Book Review (1944) 54 Y ALE L. J. 178.

15. See generally 12 U. S. C. $\$ \$ 21$ et seq. (1940); 31 U. S. C. $\$ \$ 311$ et seq. (1940). For general discussion of the monetary power and a summary of older legislation in the field see Wiliss, Constitutronal LaW (1936) 394-407.

The decision of the Supreme Court in the great case of McCulloch v. Maryland, 4 Wheat. 315 (U.S. 1824) is indicative of the broad compass of these powers. 
foreign currency. For example, the counterfeiting statutes extend to protection of currencies of foreign governments. ${ }^{10}$ As long ago as 1897 Congress recognized that the stability of the dollar was affected by the behavior of other monetary units. By an act adopted in that year it was provided that the President could nominate delegates to any international conference designed to work out rules of monetary parity. ${ }^{17}$ A series of statutes enacted in 1933 and subsequent years have directly authorized the President and the Secretary of the Treasury to undertake credit operations and enter into agreements with other nations for the purpose of maintaining the ratio of the dollar to other currencies, at a basis which will protect the foreign commerce of the United States. ${ }^{18}$ In 1935, the general Export-Import Bank was established with authority, among other things, to loan money to foreign governments or central banks to help stabilize their currencies. ${ }^{13}$

In point of fact, economists have long recognized that Congress cannot exercise its powers to deal with problems of domestic currency issue and of domestic banking regulation without affecting international financial policy and the foreign relations of the United States. Conversely, it is impossible to deal with problems of international finance without affecting the domestic monetary and banking situation. Perhaps the most dramatic demonstration of the interdependence of the two aspects of the financial policy is furnished by the Gold Reserve Act of 1934. The majority of the provisions of the Act deal with questions of primary domestic import, such as reserve ratios, the issuance of bank notes, and the redemption of circulating media; but Section 10 thereof authorized the Secretary of the Treasury to deal in gold and foreign exchange "for the purpose of stabilizing the exchange value of the dollar." 20 A fund of two billion dollars was created for this purpose.

The first currency stabilization agreements made by the United States were those negotiated with a number of South American countries during the first World War, by virtue of authority conferred upon the President in the Second Liberty Loan Act. ${ }^{21}$ More enduring in

16. See United States v. Marigold, 9 How. 560 (U. S. 1S50); United States v. Arjona, 120 U.S. 479 (1887).

17. 29 STAT. 624 (1597), 31 U. S. C. $\$ \S 311,312$ (1940). Of course, the contemplated conferences were directed toward the problems of monetary bimetallism, but the principle of international monetary cooperation was clearly envisioned.

18. See, e.g., 48 Stat. 51 (1933), 31 U. S. C. $\$ 314$ (1940); 4 S Stat. 337 (1934), 31 U.S. C. $\$ 440(1940) ; 48$ STAT. $1178(1934), 31$ U.S. C. $\$ 448(1940)$.

19. 49 Stat. 4 (1935), 15 U. S. C. $\$ 713 \mathrm{~b}$ (1940). Two previous banls had been established by executive order authorized by legislation in 1933 to handle trade transactions nith the USSR and to extend credits to Cuba to help support that nation's currency. Sca DiETRICH, WORLD TRADE (1939) 74-5. In addition to the stabilization of foreign currencies, the Export-Import Bank grants long term credits to promote American esports. Sce $i d$. at 193-S, and the Annual Reports of the Export-Import Banls of Washington.

20. 4S STAT. 341 (1934), 31 U. S. C. § \$22a (1940).

21. 40 Stat. 966 (1918). 
effect was the eight-power silver agreement.negotiated by the United States during the London Economic Conference of 1933,22 in effectuation of the policies enunciated in Title 3 of the Agricultural Adjustment Act of $1933 .{ }^{23}$ Probably the closest analogue to the proposed International Monetary Fund is the series of stabilization agreements negotiated pursuant to the Gold Standard Act of 1934, and its successors. ${ }^{24}$ The most important of these compacts is the Franco-AmericanBritish oral agreement of 1936, to which Belgium, Switzerland, and the Netherlands later adhered; ${ }^{25}$ in subsequent years, similar agreements were negotiated with five other nations. ${ }^{26}$ These agreements provided for cooperation between the fiscal agencies of the signatories in order to stabilize the gold ratios of their currencies. The FrancoBritish-American agreement also provided for loans of gold or foreign exchange between the various stabilization funds when necessary to prevent excess fluctuations. Another interesting precedent is the Chinese-American agreement of 1942 whereby the United States created an open-end credit of $\$ 500,000,000$ to help stabilize the Chinese currency. ${ }^{27}$

From the legal standpoint the most significant fact about these stabilization arrangements is that every one of them was effected by Congressional-Executive agreement. In fact there is no known instance when an international monetary arrangement to which the United States was a party was validated by the treaty process. ${ }^{28}$

2. The Foreign Commerce Power. To the extent that the proposed International Bank for Reconstruction and Development and the Monetary Fund seek to promote the foreign commerce of the United States by helping to create a new and better integrated world economy,

22. U. S. Exec. AGreeu't Ser., No. 63 (1933); see also President Roosevelt's proclamation, 48 Stat. 1723 (1933).

23. 48 Stat. 51 et seq. (1933). This part of the Act was not invalidated by the decision in Butler v. United States, 297 U.S. 1 (1936).

24. 48 Stat. 341 (1934), as extended by 50 Stat. 4 (1937), 53 Stat. 998 (1939), 55 Stat. 395 (1941), and 57 STAT. 68 (1943), 31 U. S. C. § 822a (Supp. IV, 1941-45).

25. See (1936) 22 Fed. Reserve Bull. 759, and Part I, p. 280.

26. See U. S. Treasury Dep'T, Annual Report of teE Secretary of tue Treasury FOR 1938 (1939) 21, 268 (Brazil), REPORT FOR 1941 (1942) 52, 358 (China), and REPORT FOR 1942 (1943) 42, 291-2 (Mexico, Ecuador, and Iceland).

In 1941, Secretary of the Treasury Morgenthau agreed not to consummate any additional stabilization agreements without consulting the Congressional Money and Banking Committees. See Nussbaum, International Monetary Agreements (1944) 38 Asr. J. INr. I. 242,251, n. 56.

27. See 56 Stat. 82 (1942); 6 Dep't of State Bull. No. 144, p. 263. An carlier gtabilization loan to China was made in 1941. See note 26 supra.

28. An inter-American bank agreement was drafted in 1942, presumably intended for ratification by the United States as a treaty, but was never ratified by any of the signatories. See Nussbaum, International Monetary Agreements (1944) 38 AM. J. INT. L. 242, 252. 
to replace the economy which has been broken into isolated trade areas since 1930, our participation represents merely an extension of traditional Congressional powers. ${ }^{29}$

We have already discussed in some detail the extent and frequency with which Congress's powers in the field of foreign commerce have been used throughout our national history to authorize agreements with other nations. ${ }^{30}$ The earliest agreements in this field-dealing with reciprocal trade and navigation arrangements - were enacted at the very beginning of the nineteenth century. ${ }^{31}$ The reciprocal trade agreements program initiated in the 1890 s under the administrations of Harrison and MICKinley and brought to fruition in 1934 and subsequent years by Secretary of State Hull, with the full cooperation of Congress, works on the premise that the interests of the United States are best subserved by permitting growth of our imports concomitant with an expansion of export trade. ${ }^{32}$ The late President Roosevelt announced shortly before his death that he would seek legislation permitting extension of the Hull program of general tariff reduction in the post-war years. ${ }^{33}$ President Truman has urged prompt action on the program, and Congress has recently enacted legislation extending and expanding the powers of the President to lower tariff rates by agreements with other nations.

Whether or not one approves of the details of specific reciprocity agreements, it is clear that the foreign commerce of the United States can expand only if the economies of other nations operate at high levels of productivity. During the 1920 s and 1930 s artificial stimulants were given to our export industries, to offset the heavy balance of exports of

29. The close relation between the Bretton Woods proposals and American foreign trade was explained by Secretary of the Treasury Morgenthau in the following words:

"What are the fundamental conditions under which the commerce among the nations can once more flourish?

"First, there must be a reasonably stable standard of international exchange to which all countries can adhere without eacrificing the freedom of action necessary to meet their internal economic problems.

"This is the alternative to the desperate tactics of the past-competitive currency depreciation, excessive tariff barriers, uneconomic barter deals, multiple currency practices, and unnecessary exchange restrictions-by which governments vainly sought to maintain employment and uphold living standards. In the final analysis, these tactics only succeeded in contributing to world-wide depression and even war. The International MIonetary Fund agreed upon at Bretton Woods vill help remedy this situation."

Closing address to the Bretton Woods Conference, July 22, 1944, reported in In:IEn:satro:ant Monetary Fund and International, Bank for Reconstruction nisd Develobretix (U.S. Treas. Dep't 1941) iv-v.

30. See Part I, Section IV.

31. 3 Stat. 224 (1815); 4 Stat. 2 (1824); 4 Stat. 308 (182S); 4 Stat. 419 (1830); c2e also 3 MIILER, TREATIES, at 521.

32. See Part I, pp. 273-5.

33. See N.Y. Times, March 27, 1945, p. 1, col. 3. 
goods over imports by imports of gold and by sales of foreign bonds with over-all interest requirements exceeding the reasonable ability of the borrowers to defray. The Bank proposes to replace these dubious expedients by a carefully devised long-run program for building up the economies of nations which are chronic debtors on international account. ${ }^{34}$

In recent years, the Congressional power to regulate foreign commerce has often been used to assist in the industrialization of other countries or in the stabilization of the currencies of other governments. Thus the Export-Import Bank, whose functions in this field have previously been outlined, had, up until March 1944, made 120 loans to 28 foreign governments to facilitate exports of American capital goods or agricultural products. One of the most important of these loans was that authorized by the Hull-Aranha agreement of 1942, whereby funds were provided to finance exports necessary for the industrialization of Brazil. ${ }^{35}$ The UNRRA agreement, adherence to which was authorized by Congressional joint resolution and appropriation acts, has established a source of funds to assist in providing relief and minimal rehabilitation to war-torn areas. ${ }^{36}$ Similarly, the Foreign Economic Administration and its predecessor organizations have entered into numerous developmental contracts with South American nations, usually through the media of the Rubber or Metals Reserves Corporations, or some other instrumentality of the Reconstruction Finance Corporation.

On policy grounds there are a number of important reasons, in addition to the general considerations discussed in Section VII of this article, why the question of adherence to the Bretton Woods organizations should be determined by majority vote of both houses. In the first place, the relationship between the proposed international monetary organizations and domestic monetary legislation is so intimate that it is appropriate to utilize the same legislative procedure in both situations. It would be almost grotesque statesmanship to exclude the House, which under the Constitution ${ }^{37}$ and governmental practice plays a major role in controlling internal financial policy, from participation in control of the United States' policy with regard to international finance. In the second place, the necessity of implementing American membership by appropriations of the prescribed national

34. Ibid; see also Bryce, International Aspects of an Investment Program in HaRR1s (ed.), Postwar Economic Problems (1943) 361-75; Nathan, Mobilizing for AdundANCE (1944).

35. See Dep't of State, Press Release, March 11, 1939; see generally testimony of Warren Pierson, Hearings before Committee on Appropriations of the Honse of Representatites on the Foreign Economic Administration Appropriation Bill for 1945, 78th Cong., 2d Sess. (1944).

36. See Part I, p. 273.

37. Thus under the Constitution revenue bills must originate in the House. U. S. Const. Art. $1, \S 7$, cl. 1. 
quota will require House action on the agreements in any case. Since the House is not likely to vote appropriations if it does not approve of the purposes of the proposed international organization, the possible breach of faith with other nations embodied in failure to provide funds is most likely to be avoided if the House participates in the initial decision as to United States membership. ${ }^{3 s}$ In the third place, full participation by the United States in the Fund and the Bank may entail conflict with existing statutory provisions. For example, the Johnson Act of $1934^{39}$ precludes American citizens and corporations from loaning money to foreign governments which are in default to the United States. ${ }^{40}$ It may be assumed that the Bank and Fund will malie loans to nations in default to the United States. Since the Fund and Bank are international organizations, they are not of course subject to the provisions of domestic legislation. However, a due respect for the prerogatives of the whole Congress makes it desirable to effectuate American participation in an international organization which will use American-contributed funds contrary to established legislative policy in a manner where the voice of the whole Congress may be heard. Moreover, in the interests of economy, it is contemplated that a substantial portion of the Stabilization Fund established by the Gold Reserve Act of 1934 will be transferred by the Treasury to the International Monetary Fund, as a portion of the agreed American quota. $\$ 1$ It is not only appropriate, but probably constitutionally requisite, that a transfer of funds from an agency and a function established by act of Congress to a new agency, carrying on a related but distinguishable function, should be authorized by vote of both houses. ${ }^{42}$

In summary, ample precedents of law and important policy considerations sustain the conclusion that the adherence of the United States to the International Monetary Fund and the International Bank for Reconstruction and Development should and may be effected by the democratic procedure of a majority vote of both houses of Congress. The whole Congress, which had and used the power to

38. The House of Representatives has always taken the position that it need not appropriate funds called for by a treaty approved by Senate and President unless it approved of its objects. See Part I, p. 306 and p. 336, n. 126.

39. 48 STAT. 571 (1934), 31 U. S. C. $\$ \$ 04 a$ (1940). The Export-Import Banls Act, 49 StAT. 4 (1935), 15 U. S. C. $\& 713$ b (1940), also prohibits loans to foreign governnzents (or their central banks) which are in default to the United States.

40. Among the nations thus locked in chancery are Russia (because of the dispute as to the Czarist and Kerenshy indebtedness), most of our allies in the first World War (as a result of the Hoover moratorium of 1931 and the subsequent defaults on war indebtednes3), and many Latin American states (in default on private account).

41. See $\$ 8(a)$ of H. R. 2211 and of S. 540, 79th Cong., 1st Sess. (1945).

42. While it is true that in case of inconsistency between the provicions of a treaty and a statute the most recent instrument prevails, we know of no case in which it has been held that an appropriations provision in a statute can be altered by a later treaty dealing vith the same or a related subject matter. 
make war in 1941, has and can use the power in 1945 to assist in binding the wounds of war and to ordain a charter of economic peace, which will protect the exchange stability of the dollar and promote the foreign commerce of the United States.

\section{The Proposed Security Agreements - Cooperation to Prevent War.}

The history of the world in the two decades between the first and second World Wars has led most observers to conclude that the future maintenance of international peace depends both upon the establishment of an enduring alliance between the major members of the United Nations and upon the creation of some type of organization capable of directing sanctions against would-be aggressors with a minimum of delay. It has become increasingly clear that in the international sphere, as well as within any single nation, the only ultimate guarantee that society possesses against recurrent outbreaks of lawlessness and violence is the presence of effective law-enforcing agencies. It is also generally agreed that an international agency which is to be charged with the task of preventing aggression and averting violence between nations must be able to perform a number of functions and must have at its disposal a considerable variety of weapons. The prime function presently proposed for an international security organization is indeed not so much that of curbing aggression by force, as it is that of concerting efforts to adjust conflicts between nations by peaceful means and of providing a forum for the amicable readjustment of international agreements in response to changes in economic and social conditions and to the shifting balance of political and military power. It is recognized, however, that such an organization, to be effective, must be able to direct the immediate imposition of diplomatic and economic and, where necessary, military sanctions against would-be aggressors. This requires that the organization be able to act on occasions of crisis through the votes of the delegates from the various participating nations, acting upon orders from their respective chiefs of state, and without awaiting time-consuming specific authorization from the legislative bodies of the member nations.

In the age of the robot bomb, rocket warfare, and the giant airplane, the constant threat of promptness in the imposition of sanctions offers the only hope not only of success in maintaining peace, but perhaps even of avoiding destruction. Confronted with the certainty that an overwhelming force stands ready, and will promptly be used, to prevent breaches of the peace or to halt attempts to overthrow by violence obligations incurred by solemn agreement, the most aggressive of nations may hesitate to unleash the instruments and horrors of war. History furnishes abundant examples, on a smaller scale, which demonstrate the effectiveness of marshalling force against an aggressor to forestall the commencement of hostilities. Thus, Theodore Roosevelt 
impelled withdrawal of the German blockading fleet from Venezuela in 1902 by mobilizing a fleet in the Caribbean. ${ }^{43}$ The mobilization of American troops along the Mexican border in 1865-1866 was one of the factors which induced Emperor Napoleon III of France to withdraw his army from Mexico. ${ }^{44}$ Competent observers have suggested that the march of the Nazi troops into the Rhineland in 1936 and the occupation of Austria in 1938 might never have occurred if there had been an indication that these mores would be resisted by other States. ${ }^{45}$ It is to be expected, however, that just as the introduction of law and order into a frontier community proceeds from the vigilante stage, where threats of force frequently metamorphose into the actual use of force, to the urban stage, where the mere presence of the police deters lawlessness, so also as an international security organization develops more efficient procedures for the speedy mobilization of its component units, its own role will become primarily that of acting as an in tcrrorem threat to would-be aggressors. The organization will thus provide greater security, with less actual resort to force.

Twice in 25 years the American people have seen the policy of abstention from active participation in the councils of the peace-loving nations and from participation in the settlement of international disputes bring us to the brink of national disaster. TTe have learned that in the twentieth century the boundaries of our safety and freedom may sometimes be on the Rhine and the Manchurian border. In elections, in opinion polls, and in all modes of public expression, the people of the United States have indicated by large majority that they desire this nation to play an active part in an international security organization. Responsible leaders of both parties have united in insisting that the representatives of the United States in such an organization must be authorized to speak for the United States in critical situations, without awaiting specific authorization from Congress as each crisis arises. ${ }^{40}$

Absent effective American participation, moreover, it is probable that not only will the effective operations of the Security Council be greatly retarded, particularly in this hemisphere, but also that our European and Asiatic allies will become convinced of the unwillingness

43. See 2 Thayer, Life of JoHn HAY (1915) 286-3; Demis, Adventunes Izi AluerICAN DiplosiacY, 1896-1906 (192S) 290-1; Latané aNd Warnhouse, Arienicili Foneig: Policy (2d rev. ed. 1941) 491-3. But see 2 V.agts, Deutscalahd usd diE Veremigte: STAATEN IN DER WELTPOLITIE (1935) 1619-20.

44. See Besis, Diplonlutic History of the United States (1942 ed.) 393-4. As to the international law aspects, see Lawrexce, Prnnciples of INtenmationil Lut (3d ed. 1900) 124; 1 Hyde, INTERNational Law (1922 ed.) 119-20.

45. For other early examples see LawnENCE, op. cit. satpra note 44, at 125-30.

46. See President Roosevelt's speech to the Foreign Policy Association, reprinted in N. Y. Times, Oct. 22, 194t, p. 34; Senator Arthur H. Vandenterg, Lat's Try to Precart World War III, Saturday Evening Post, Miarch 17, 1945, p. 17; statements by Sanators Ball, Burton, and Austin, U.S. News, Nov. 3, 1944, pp. 36, 40. 
of the United States to assume the international obligations necessary to preserve the peace and will, perforce, return to the most naked and transient balance of power politics. ${ }^{47}$ In this eventuality it is not unlikely that, as in the 1920s and 1930s, there would develop a state of discord between our erstwhile major European allies ${ }^{48}$ in which fascist governments could once again rise to power and develop the strength with which once more to embark upon the paths of aggression.

The representatives of more than 45 nations gathered in San Francisco and agreed upon a draft of the constitution of a general international organization. The tentative blueprints which were the starting point for the Conference's work were drafted in the spring and summer of 1944 by representatives of the leading powers at the Dumbarton Oaks Conference and have since been the subject of discussion in protracted exchanges of diplomatic correspondence. The proposed organization is to include a General Assembly in which all member States are to be represented, a Security Council to which is entrusted the primary responsibility for the averting of war, a Social and Economic. Council to coordinate the activities of existing and projected international agencies in these fields, an International Court of Justice, a Trusteeship Council, and a Secretariat. ${ }^{49}$

The "primary responsibility for the maintenance of international peace and security" ${ }^{50}$ is vested in the Security Council. Accordingly, the realistic proposal is made that the present and probable future "super-powers"- - the United States, Russia, Great Britain, China, and France-have permanent seats on the Council. In addition to the five representatives of these nations, the Council is to include 6 delegates elected by the Assembly. ${ }^{51}$ Building on the principle used in Article 31 of the Statute of the Permanent Court of International Justice, ${ }^{52}$ it is also recommended that any State not represented on the Council should, "if it is a party to a dispute under consideration by the Security Council . . . be invited to participate in the discussion relating to the dispute." ${ }^{53}$ It is proposed that the permanent members of the Council,

47. Recent commentators on the Treaty of Versailles have pointed out that the recession from the original French demands for restrictions on Germany were motivated in large measure by a belief that the United States would participate actively in the League of Nations and would join with Great Britain in coming to France's aid in the event of another Teutonic invasion. See stipra, Section VII, note 165. In effect, therefore, we urged a policy of extreme, perhaps injudicious, moderation on the French and then withheld the support on whose expectation they yielded to our suggestions.

48. See Wolfers, Britain and France Between Two Wars (1939).

49. See the Charter of tae United Nations (1945) c. III, reprinted in N. Y. Times, June 27, 1945, pp. 12, 13 (hereinafter cited as ChARTER).

50. Charter, c. V, art. 24 , par. 1.

51. Id. at art. 23 , pars. $1,2$.

52. P. C. I. J., Ser. D, No. 1 (3d ed. 1936) at 19.

53. Charter, c. V, art. 32. 
including the United States, have an absolute veto on any imposition of military sanctions. ${ }^{54}$

To some degree the general scheme envisioned in these blueprints for averting international conflicts is comparable to that already in use in the United States to prevent industrial strife in industry. ${ }^{.5}$ As the first measure, it is proposed that the Council and the Assembly be empowered to investigate any situations deemed likely to flare into conflict. ${ }^{56}$ The grant of power in this field to the Council is broad enough to aid "in bringing about those peaceful adjustments between states which require something more drastic than the application of existing law." 57 Moreover, the network of proposed international economic and social organizations may be expected to remove or ameliorate many of the frictions which have in the past embittered international relations. In the second place, to ensure a "cooling-off" period, it is proposed that:

"1. The parties to any dispute, the continuance of which is likely to endanger the maintenance of international peace and security, shall, first of all, seek a solution by negotiation, inquiry, mediation, conciliation, arbitration, judicial settlement, resort to regional agencies or arrangements, or other peaceful means of their own choice.

"2. The Security Council shall, when it deems necessary, call upon the parties to settle their dispute by such means." :s

In the third place, the Security Council is empowered to require submittal of an unsettled international controversy whose continuance is "in fact likely to endanger the maintenance of international peace and security" to a mediating agency of its own designation or, if justiciable questions are involved, to the new International Court. ${ }^{\circ 9}$ In the case of non-justiciable disputes, it is apparently contemplated that the ultimate proposals for compromise may come from the Council itself. ${ }^{(3)}$

In the event, however, that an aggressor State declines to follow the paths of settlement by negotiation and mediation, the Security Council is empowered to take any measures necessary to prevent a breach of peace or to bring the perpetrator of such a breach to heel. The relevant portions of the San Francisco Charter read in part as follows:

54. Id. at art. 27, par. 3.

55. See Garrison, The National Railroad Adjustment Board: A Unique Administratice Agency (1937) 46 YALE L. J. 567.

56. As to the functions of the Assembly see Creirter, arts. 10-14; as to the Council see id. at arts. 33-51.

57. Corbetr, The Dunbarton Oafs Plas (Yale Institute of International Studies, Memorandum No. 13, 1941) 6. The language is equally applicable to the San Francisco Charter.

58. Ceharter, c. VI, art. 33, pars. 1, 2.

59. Id. at arts. 36,37 .

60. See $i d$. at art. 38 . 
"Article 39. The Security Council shall determine the existence of any threat to the peace, breach of the peace, or act of aggression and shall make recommendations, or decide what measures shall be taken in accordance with the provisions of Articles 41 and 42 , to maintain or restore international peace and security.

"Article 40. In order to prevent an aggravation of the situation, the Security Council may, before making the recommendations or deciding upon the measures provided for in Article 41, call upon the parties concerned to comply with such provisional measures as it deems necessary or desirable. Such provisional measures shall be without prejudice to the rights, claims, or position of the parties concerned. The Security Council shall duly take account of failure to comply with such provisional measures.

"Article 41. The Security Council may decide what measures not involving the use of armed force are to be employed to give effect to its decisions, and it may call upon members of the United Nations to apply such measures. These may include complete or partial interruptions of economic relations and of rail, sea, air, postal, telegraphic, radio, and other means of communication, and the severance of diplomatic relations.

"Article 42. Should the Security Council consider that measures provided for in Article 41 would be inadequate, or have proved to be inadequate, it may take such action by air, sea or land forces as may be necessary to maintain or restore international peace and security. Such action may include demonstrations, blockade, and other operations by air, sea or land forces of members of the United Nations.

"Article 43. 1. All members of the United Nations, in order to contribute to the maintenance of international peace and security, undertake to make available to the Security Council, on its call and in accordance with a special agreement or agreements, armed forces, assistance, and facilities, including rights of passage, necessary for the purpose of maintaining international peace and security.

2. Such agreement or agreements shall govern the numbers and types of forces, their degree of readiness and general location, and the nature of the facilities and assistance to be provided.

3. The agreement or agreements shall be negotiated as soon as possible on the initiative of the Security Council. They shall be concluded between the Security Council and member states or between the Security Council and groups of member states and shall be subject to ratification by the signatory states in accordance with their constitutional processes.

"Article 44. When the Security Council has decided to use force it shall, before calling upon a member not represented on it to provide armed forces in fulfillment of the obligations assumed under Article 43 , invite that member, if the member so desires, to participate in the decisions of the Security Council concerning the employment of contingents of that member's armed forces.

"Article 45. In order to enable the United Nations to take urgent 
military measures, members shall hold immediately available national air force contingents for combined international enforcement action. The strength and degree of readiness of these contingents and plans for their combined action shall be determined, within the limits laid down in the special agreement or agreements referred to in Article 43, by the Security Council with the assistance of the Military Staff Committee." 6i

The detailed merits or demerits of specific items in these proposals are not, of course, germane to the question of the constitutional procedure by which the United States may enter into an international security organization or even to the general policy issue of whether the United States should adhere to some such organization.

Two general comments, however, are in order. In the first place, the plan emerging from international conferences is hardly likely to embody all the details of every statesman's personal blueprints, or to be wholly pleasing to every nation or to every group in any particular nation. Politics, it has been said, is the art of the possible, and compromise is as necessary in the international as in the municipal or national sphere. But when a detailed plan for establishing an international organization secures the imprimatur of representative delegates from more than forty-five nations it is to be hoped that the legislative bodies which pass upon the question of adherence will not allow minor objections to frustrate the supreme cause of international cooperation. ${ }^{62}$

61. Id. at arts. 39-45. See also arts. 46-54.

62. It may be appropriate to recall the words with which Benjamin Franllin advisad his fellow delegates to the Constitutional Convention of 1787 to sign the proposad Constitution of the United States:

"I confess that there are several parts of this Constitution which I do not at present approve, but I am not sure I shall never approve them. For having lived long, I have experienced many instances of being obliged by better information, or fuller consideration, to change opinions even on important subjects. which I once thought right, but found to be otherwise. It is, therefore, that the older I grow, the more apt I am to doubt my own judgment, and to pay more respect to the judgment of others. . . . Thus, I consent, Sir, to this Constitution, because I expect no better, and because I am not sure, that it is not the best. . . . On the whole, Sir, I cannot help expressing a wish that every member of the Convention who may still have objections to it, would, with me, on this occasion doubt a little of his own infallibility, and to make manifest our unanimity, put his name to this instrument."

Similarly Delegate James MicHenry of Maryland stated in part:

"Being opposed to many parts of the system, I malse a remarls why I signed it and mean to support it. 1st. I distrust my own judgment, especially as it is opposite to the opinion of a majority of gentlemen whose abilitics and patriotism are of the first cast; and as I have had already frequent occasions to be convinced that I have not always judged right."

WarReN, The MakTNG OF THE Constrtution (1937) 709, 710-1.

One hundred years before, Oliver Cromwell had urged a group of dissident clergymen to yield to a majority view: "My brethren, in the name of Christ, I beseach you to thinls it possible that you may be mistaken." Id. at 709. 
In the second place, it is apparent that the general international organization and particularly the Security Council, while recognizing the juristic equality of all States, ${ }^{63}$ will realistically accord the dominant roles to those larger States which have borne the major burden of the war against the Nazi-Japanese aggressors and which must, as a practical matter, assume the major responsibility for preventing future aggressions. It should not, however, be concluded that the Organization will represent a dictatorship of the great powers or that it will injure the interests of the smaller nations. Against such fears, often coming from those who until the very eve of Pearl Harbor opposed American assistance to the United Nations, should be set the reasoned comment of the distinguished Canadian expert, Professor Corbett:

"The proposed organization will not lessen any existing protection which the small states have against the great. No charter is required to put the great powers on top of the heap. They are there already.

"That is the situation in fact. As for the situation in law, the very rule of unanimity among the permanent members of the Security Council will tend to prevent the use of the organization in any oppressive manner. Most small powers will find at least one friend among the permanent members. Moreover, if they vote together, the small states can veto action by the Council. The organization will not be any easy vehicle for great-power dictation. If that were its purpose, a coalition without any setting of general organization would be less hampered.

". . . The League of Nations was extremely kind to the formal status of the small countries, and extremely ineffective in their substantial protection. This time the great powers on the Security Council will pay for a privileged position by an unequivocal acceptance of responsibility for enforcement of the new covenant." 04

Nor is the general international organization the only type of forthcoming security organization which invites participation by the United States. At the recent Mexico City conference of American States, a proposal was made to extend the Monroe Doctrine and the 1940 Act of Habana ${ }^{65}$ by an agreement to prevent acts of aggression by any of the Republics in the Americas against their sister States. By the Act of Chapultepec, the various American Republics agreed to consult and, if necessary, to join in using military force to restrain such aggressions. ${ }^{60}$

63. Charter, cc. II, XIV.

64. CORBETT, op. cit. supra note 57 at 6 .

65. See Part I, pp. 271-2

66. See N. Y. Times, March 4,1945 , p. 25, cols. 2-6. The San Francisco Charter explicitly encourages the devisal of regional security organizations. See c. VIII. However, Article 53 provides that

"1. . . . no enforcement action shall be taken under regional arrangements or by regional agencies without the authorization of the Security Council, with the 
The United States was one of the primary authors of this agreement and naturally is expected to play an important role in its effectuation. ${ }^{77}$ Additionally, it may be anticipated that considerable attention will be given in the next few years to direct bilateral or multilateral defense agreements analogous to the recently consummated Canadian-United States, Anglo-Russian, and Franco-Russian pacts. ${ }^{\text {cs }}$ It may be expected that the United States will enter into direct agreements with the other permanent members of the Security Council with regard to the fulfilment of their joint obligations.

Of the general, over-all constitutional power of the United States, by one procedure or another, to enter into security agreements with other nations and to assume and fulfil all of the obligations that membership in an international security organization may entail, there can appear to be no reasonable doubt. ${ }^{69}$ As Professor Quincy Wright has recently written:

"The United States is a sovereign state and can exercise its sovereignty to assume any kind of obligation which is not contrary to the powers of sovereign states under international law. The assumption of obligations of alliance, guarantee, mutual assistance, collective security, and sanctions has been habitual among states and so long as these obligations aim to maintain international law and not to deprive other states of rights under international law they are undoubtedly consistent with that law. It is also clear that the federal government has power without any limitations from the 'reserved powers' of the states to assume obligations on any subject within the sphere of international relations." "so

exception of measures against any enemy state, as described below, provided for pursuant to Article 107, or in regional arrangements directed against renewal of aggressive policy on the part of any such state, until such time as the organization may, on request of the governments concerned, be charged with the responsibility for preventing further aggression by such a state.

"2. The term 'enemy state' as used in Paragraph 1 of this article applies to any state which during the second World War has been an enemy of any signatory of the present charter."

67. One of the advantages of the Security Council to the United States is that it would make it possible for this government to talse effective action in Latin America to prevent conquests by any future neo-fascist aggressors, without leading to a revival of the charge of "Yankee imperialism," as might be the case if the United States took action on its omn initiative.

68. As to the 1940 Canadian-American defense pact see N. Y. Times, Aug. 19, 1940, p. 1, col. 4; N. Y. Times, Aug. 20, 1940, p. 1, col. 1; (1940) 3 Dept. of State Bull., No. 61, p. 154. The Franco-American alliance of 1778 is an earlier esample of American participation in limited agreements for international military cooperation. See supra, pp. 549-50.

69. Any argument that the United States may not join a security organization because it would thereby surrender a part of its "sovereignty" is sophistical. See Conwr:, TaE Constitution AND World Organization (1944) cC. 1-2. None of the other great powers seems to be deterred by such considerations.

70. Wright, Constitutional Prncedure in the Untited States for Carrying out Oblighations 
Coming down to procedures, it is clear that the United States can accept membership in a security organization, as in any other international organization, by either treaty or Congressional-Executive agreement; that it can assume the obligations that are indispensable to an effective security organization by either treaty or CongressionalExecutive agreement; and that it can fulfil these obligations by drawing as occasion may require upon the powers of both the Congress and the President.

\section{Constitutional Procedures for Accepting Membership in a Security} Organization. The first problem, that of formal acceptance of membership in a security organization, presents no new issues. ${ }^{71}$ It has already been seen that there is no unique quality in an agreement establishing an international organization which differentiates it for purposes of constitutional validation from any other type of international agreement. Nor would there appear to be any reason in law or policy for distinguishing for this purpose an international security organization from any other type of international organization. All of the commitments which acceptance of membership in a security organization involves are clearly within the combined powers of the Congress and the President both to make and to fulfil. The constitutional investiture of power with respect to the two principal sanctions which it is presently proposed to make available to a general security organization-the imposition of trade embargoes and the use of military forces ${ }^{72}$-is clear and direct:

"The Congress shall have power ... to regulate commerce with foreign nations ... to declare war . . . to make rules for the government and regulation of the land and naval forces." 73

To these broad powers, there may be added, in the procedure of the Congressional-Executive agreement, the powers of the President as Commander-in-Chief, as the Executive, and as sole organ for the conduct of negotiations with other governments. It is patently beyond reason to suggest that all these powers of the Congress and the Presi-

for Military Sanctions (1944) 38 AM. J. INT. L. 678, 679. In support of his position, Professor Wright cites Geofroy v. Riggs, 133 U.S. 258 (1890) and his own Control or AMEnICAN Foreign Relations (1922) 121-6, 247-8. See also United States v. Curtiss-Wright Export Corp., 299 U. S. 304 (1936); Mitchell, The Constitution and the Treaty to Prevent War (1945) 31 A. B. A. J. 59.

71. Exactly the same legal problems are at issue whether we consider a gencral sccurity organization or a bi-, tri-, or quadrilateral alliance. In the interests of simplicity the discussion which follows will relate explicitly only to a general security organization.

72. As will be presently demonstrated, the President has overlapping powers with Congress in directing the extraterritorial use of American troops or naval forces to a considerable degree.

73. U.S. Const. Art. I, $\$ 8$. 
dent, which explicitly include the power to declare and wage war ${ }^{72}$ and which have been held by the Supreme Court to include the power to terminate war, ${ }^{75}$ do not also include the corollary power to authorize the adherence of the United States to an international organization designed to avert war. As Congressman Bayly of Virginia said 100 years ago: "It has always been admitted, in the administration of the government, that the power to declare war carrics vith it the power of doing whatever tends directly to prevent it." is

Despite the fact that the President and the Senate alone do not have the constitutional power to fulfil all of the commitments which acceptance of membership in an international security organization may involve, it would appear that the treaty-maling procedure may also be used to authorize both this government's acceptance of membership in such an organization and its assumption of all necessary obligations. This is the recent reasoned conclusion of former Attorney General William D. Mitchell, who points out that security is an appropriate subject matter of international agreement and that "a treaty should not require the aid of legislation merely because it operates in a field in which the Congress may legislate." $\pi$ He finds that "there is plausible ground for the opinion that the treaty alone" would give the President the necessary authority to act, "alway's with the qualification that the Congress must supply the money," and concludes realistically that "if prevailing public opinion approves the treaty, and the Senate by a two-thirds vote ratifies it, the House should, and doubtless would, join in appropriate legislation to make it effective and enable the President to act promptly." is

The late President Roosevelt and the Department of State indicated that, in the first instance, the questions of adherence by the United States to the United Nations Organization and to the Act of Chapultepec would be presented in the form of a treaty, and President Truman has followed this procedure. ${ }^{79}$ Since a number of Senators long committed to the cause of international cooperation have expressed belief that the treaty clause is the appropriate constitutional method for validating membership of the United States in a security organization, this was undoubtedly the wise statesmanship of an attempt to avoid a controversy over constitutional procedure. The lack of understanding of the historical use and legal consequences of the CongressionalExecutive agreement is still pervasive. However, by including mem-

74. Ibid.

75. See Part I, pp. 2S6-7.

76. Cong. Globe, 2Sth Cong., 2d Sess. (1S45) app., p. 122.

77. Mitchell, szspra note 70, at 61.

78. Id. at 61 .

79. As to the security organization see N. X. Times, March 2, 1945, p. 12; as to the Act of Chapultepec see N. Y. Times, March 4, 1945, p. 25. 
bers of the House of Representatives in the delegation to the San Francisco Conference, President Roosevelt made clear his belief that both houses have a vital interest in the role of the United States in the proposed organization. If a Senatorial minority should seek to thwart our membership, it is to be assumed that a contemporary President will be as ready as were Presidents Tyler, Polk and McKinley, when confronted with analogous problems, to take advantage of the flexibility of the Constitution and to attain the goal desired by the American people through the joint resolution process.

Indeed there are weighty considerations which make use of the Congressional-Executive agreement a more desirable method than the treaty for effecting United States membership in a security organization. Since, as already indicated, the two principal weapons of such an organization depend ultimately upon powers expressly conferred by the Constitution upon the whole Congress, a due respect for the prerogatives of the House would seem to necessitate giving it an equal role in making the decision as to membership. Since, moreover, membership will be ineffective unless funds are appropriated to defray an aliquot portion of the expenses of the organization and to fulfil this government's other commitments-a matter upon which the House's cooperation is indispensable-it would seem sagacious to make certain in the first instance of that body's support. ${ }^{80}$ To these practical advantages should be added the fact that membership in a security organization is one problem with respect to which sections and states most obviously have no separate interests. Here certainly the most democratic procedure and the procedure best calculated to serve the interests of the whole country. would be to provide for participation in the decision by that branch of the national legislature which, since its representation is based on population, most accurately represents the views of the whole nation and which most recently has been forced as a whole to submit its stand on the issue of international cooperation to the test of the electorate.

2. Constitutional Powers for Imposition of Preventive Sanctions against Aggressors. It has been indicated that an indispensable prerequisite to an effective international security organization must be the ability of its central executive agency to invoke sanctions including, if necessary, the marshaling of armed forces against an aggressor, with

80. In 1897, the Senate Foreign Relations Committee declared: "Whenever affirmative action of either the executive or the legislative branch of the Government may involve a call upon the assistance of the other, the branch about to take action should, if possible, first obtain indications of the other's desires." SEN. Doc. No. 56, 54th Cong, 2d Sess. (1897) 5. See also George Wharton Pepper, Family Quarrels (1931) 4; Robinson, Two Reciprocity Treaties (1904) 170-1; Bloos, The Treaty-Making Power (1944) 6-7; Wright, The Control of American Foreign Relations (1922) 6, 226. 
the least possible delay. The participation of the United States in such organizations will, accordingly, be a vainglorious gesture unless the Congress is prepared to authorize the President within appropriate limits to join in the imposition of sanctions. Former Attorney General Mitchell has demonstrated that the required discretion can be vested in the President either by a treaty accepting membership in a security organization or, apart from the question of adherence, by act of Congress. ${ }^{81}$ The step we take beyond Mr. Mitchell is in suggesting that the act of Congress which grants such discretion may also authorize United States membership in the security organization itself and that any further requirement of going through the treaty process serves no functional purpose.

On various past occasions all of the three basic types of sanctions expected to be available to the Security Council have been used by the United States to secure our international interests. By constitutional theory and usage the President is vested with an almost complete control of one sanction-the exercise of the powers of diplomacy, including the recognition or non-recognition of changes in "sovereignty" over territory. The imposition of commercial and financial embargoes as well as the mobilization and preventive use of armed forces are, as pointed out above, powers vested by the Constitution in Congress. Since it is impossible to foretell under what circumstances or in what degree use of these sanctions may be necessary, Congress, to quote Mr. Mitchell again, "may state the principle to be followed and the conditions under which it is to be applied, and delegate to the President the power to determine whether the stated conditions exist, and to act accordingly." \$2 An unbroken course of legislative precedents running back to the eighteenth century indicates that the terms of such authorization may be considerably less precise than is requisite in the case of domestic legislation. The courts have always recognized that "the very delicate, plenary, and exclusive power of the President as the sole organ of the federal government in the field of international relations" 83 cannot be exercised successfully if imprisoned within too narrow borders. This is especially true with regard to the imposition of military sanctions; the constant changes in the technology of war make flexibility prerequisite to national survival. Since it has long been recognized that the President possesses powers "cognate" to those of Congress with regard to the extraterritorial use of the armed forces, as a matter of constitutional law especially extensive "delegations of power" are permissible.

S1. See Mitchell, The Conzstitution and the Trealy to Prerent Wrar (1915) 31 A. B. A. J. 59.

82. Id. at 61 .

83. United States v. Curtiss-IWright Export Corp., 299 U. S. 304,320 (1936). 
a. Imposition of Diplomatic Sanctions. It is generally acknowledged that the powers to recognize, or refuse to recognize foreign governments, and to send diplomatic representatives, or refuse to send representatives to foreign governments, are Presidential prerogatives. ${ }^{84}$ The President's power in this field stems from the fact that he is, as Thomas Jefferson stated in 1793, when Secretary of State, "the only channel of communication between this country and foreign nations." 85 The doctrine that the President's powers in this field are exclusive was initially asserted during the administration of President Washington, reaffirmed during that of President Monroe, and has been almost universally accepted since. ${ }^{86}$

On numerous occasions various Presidents have found it expedient to show their disapprobation of the conduct being pursued by the governments of foreign nations by terminating diplomatic relations or by recalling some or all of our accredited diplomatic and consular representatives. One of the best known examples is the refusal of President Wilson to recognize the Huerta regime in Mexico in 1915, which in the opinion of competent scholars helped bring about its overthrow. ${ }^{87}$ Similarly, President Franklin D. Roosevelt withdrew the American ambassadors to Germany and Italy before the declaration of war by those countries on the United States. More recently, President Roosevelt withdrew for a time part of the American diplomatic missions to the Argentine and Bolivian republics.

Another form of diplomatic sanction is embodied in the simple act of protesting against violations of international agreements, breaches of international law, or any other acts deemed harmful to international security or the interests of the United States. Such representations become particularly potent when the President is vested with authority to implement his protest by economic pressure.

b. Economic Sanctions. There has been a tendency in recent writings to underestimate the extent to which the effective imposition of economic sanctions, such as embargoes on the shipment of petroleum, machine tools, and scrap iron, can serve to forestall acts of interna-

84. See Part I, p. 305; Corwin, The President, at 216-8.

"85. Jefferson to Citizen Gênet, the French Minister, Nov. 22, 1793, 6 Writings or Thomas JeFFerson (Ford, ed., 1895) 451.

86. See 4 MemoIrs of JoHn Quincy Adans (C. F. Adams, ed., 1875) 205-6; SEN. Doc. No. 56, 54th Cong., 2d Sess. (1897); 1 Moore, Digesr, c. III.

Of course, Congress has power to adopt resolutions recommending that the President initiate or terminate diplomatic relations with any particular foreign country, but under well established precedents such resolutions are only advisory in nature. See CoRwin, TuE President, at 199-224.

87. See id. at 222; Callahan, Auserican Foreign Policy in Mexican Relations (1932) 547-51. In citing these and other examples of the use of sanctions as legal bases for analogous conduct in the future, we are of course passing no judgment upon the desira. bility of the past actions. 
tional aggression. The most effective answer to these contentions is provided by the testimony of Marshal Badoglio. In his book, La Guerro d'Etiopia, the former Italian Commander-in-Chief declared that the effective maintenance of such sanctions would have forced cessation of the Italian invasion of Ethiopa in 1936.8

From the constitutional standpoint, it is established beyond doubt that Congress's power "to regulate commerce with foreign nations" includes the power to prohibit such commerce, if deemed deleterious to the national interest, or to give the President discretion upon the occurrence of stated conditions to prohibit exports of all or any particular class of commodities to all or any particular countries. ${ }^{£}$ This power has been exercised from the first decades of government under the Constitution. The earliest example of the use of a trade embargo as a means of protecting the international interests of the United States was the act approved June 4, 1794 giving the President power to impose embargoes on shipments and ship movements from American ports when necessary to prevent depredations on American commerce. $^{.0}$ In 1799 legislation was enacted authorizing the President to suspend commercial intercourse with France and its colonies, or to re-establish trade if he deemed it desirable. ${ }^{01}$ Embargo and nonintercourse legislation was also adopted by the first Democrat-Republican administrations during the period of British and French violation of American commercial rights. ${ }^{22}$ In 1808 this legislation was held by

88. Badoglio, La Guerra d'Etiopla (1936) Preface, p. is. Spe alco Friedrucr, Foreign Policy in the Making (1938) 230; Hurngo, How to Win tae Peace (1942) 342; Morgan, Armaments and Mleasures of Enforcement in Auerracisi Councr on Poblic AFFAIRS, WORLD ORGANIZATION (1942) 155.

89. That the power to regulate foreign commerce includes the power to prohibit commerce is indicated by Article 1, Section 9 of the Constitution authorizing Congress (after 1808) to prohibit the importation of slaves. See also United States v. MIarigold, 9 How. 560, 566-7 (U. S. 1850); United States v. The William, 28 Fed. Cas. No. 16,700, at 620-3

(D. Mass. 180S); Corwin, The Cormerce Power Versus States Rughts (1936) c. 2.

In the Mrarigold case, 9 How. at 566-7, the Court said in part:

"Congress are, by the Constitution, rested with the power to regulate commerce with foreign nations; and however, at periods of high excitement, an applieation of the terms 'to regulate commerce' such as would embrace absolute prohibition may have been questioned, yet, since the paseage of the embargo and nonintercourse laws, and the repeated judicial sanctions those statutes have received, it can scarcely, at this day, be open to doubt that every subject falling within the legitimate sphere of commercial regulation may be partially or wholly excluded, when either measure shall be demanded by the safety or by the important interets of the entire nation. Such exclusion cannot be limited to particular claseas or descriptions of commercial subjects; it may embrace manufactures, bullion, coin, or any other thing. The power once conceded, it may operate on any and every subject of commerce to which the legislative discretion may apply it."

.90. 1 Stat. 372 (1791).

91. 1Stat. 615 (1799).

92. See, e.g., 2 Stat. 379 (1S06); 2 StaT. 451 (1S07). 
the United States District Court in Massachusetts to be within the ambit of Congressional authority. ${ }^{93}$ In more recent years legislation authorizing the President to embargo exportation of munitions of war to countries on the American continent to help avert warfare has frequently been enacted. ${ }^{94}$ In 1936, the Supreme Court in the CurtissWright case affirmed the constitutionality of both the prohibition of exports and the delegation of power in such legislation. ${ }^{95}$ In the Fondeutr case, the President's proclamation authorized by joint resolution, banning exports of munitions to the Dominican Republic to promote hemispheric tranquility, was enforced by injunction, although no such remedy was established in the Resolution and Congress had not made infractions a criminal offense. ${ }^{96}$

It has always been recognized that the imposition of economic sanctions could be rendered effective only if the President's authority extended to the imposition, withdrawal, or modification of sanctions as seemed to him desirable within prescribed conditions and limitations. The compass of the President's discretion has been cast in the broadest language. Thus the Act of 1794 referred to above authorized the President "whenever, in his opinion, the public safety shall so require" to lay an embargo upon all ships and vessels in the ports of the United States, including those of foreign nations "under such regulations as the circumstances of the case may require, and to continue or revoke the same, whenever he shall think proper." ${ }^{87}$ An act passed in 1806 prohibiting commercial intercourse with portions of the island of Santo Domingo contained a proviso making it lawful for the President to discontinue these prohibitions "if he shall deem it expedient and consistent with the interests of the United States." 98 Another embargo act enacted in 1806 made the touchstone of Presidential discretion the sweeping rule "if in his judgment the public interest should require it." 99 While it may not be necessary to delegate authority to the President to impose embargoes or other sanctions against aggressors in

93. United States v. The William, 28 Fed. Cas. 614, No. 16,700 (D. Mass. 1808). See also The Brig Aurora v. United States, 7 Cranch 382 (U. S. 1812). For an extensive list of early·embargo legislation see United States v. Curtiss-Wright Export Corp., 299 U. S. 304, 311-4, (1936).

94. See 42 STAT. 361 (1922), 22 U. S. C. $\$ \$ 409-10$ (1940); 48 STAT. 811 (1934), 34 U. S. C. $\S 626 \mathrm{a}(1940)$.

95. United States v. Curtiss-Wright Export Corp., 299 U. S. 304 (1936).

96. United States v. Fondeur, 3 Puerto Rico Fed. Rep. 412 (D. P. R. 1908). See also In re Debs, 158 U. S. 564, 584 (1895).

97. 1 STAT. 372 (1794). See also the unqualified grant of power in 1 STAT. 401 (1794).

98. 2 Stat. 352 (1806). See also 2 Stat. 341 (1805); 2 Stat. 528, 530 (1809).

For instructive summaries of the terms of Presidential discretion in acts designed to eliminate discriminatory trade policies see United States v. Curtiss-Wright Export Corp., 299 U. S. 304, 324, n. 2 (1936); Field v. Clark, 143 U. S 649 (1892).

99. 2 STAT, 411 (1806). 
such general language, this long record of legislative practice establishes an almost irrebuttable presumption of constitutionality for any degree of "delegation" that may be appropriate and necessary. 16s

c. The Use of Military Forces to Precent Aggression. Both the legal power to authorize the President to use force against aggressors and the practical necessity for creation of such authority have been explained with great clarity by Mr. Mitchell:

"No one familiar with the decisions on this subject would doubt the constitutionality of an Act of Congress giving the President continuing power to use our armed forces to attack aggressor nations whenever he finds that an obligation to do so has arisen under the terms of the United Nations Treaty. Such a statute would remove all ground for debate as to whether Congress must declare or authorize war. Its enactment would enable the President to act without delay. If the matter be left in such state that he could not act under the treaty in any case, without the delays incident to the passage of legislation, the aggressor could complete his conquest before we make a move. If aggressors knew such delays were probable, the treaty would have small value as a deterrent to aggression." 101

The point we add is that the requisite discretion can be equally well vested in the President by a joint resolution or act which also authorizes United States membership in the security organization. ${ }^{102}$

Since the President by virtue of his constitutional duties as Commander-in-Chief and his constitutional responsibilities to conduct the foreign relations of the United States possesses "special powers" in this field independently of act of Congress, ${ }^{103}$ statutes relating to the imposition of military sanctions may under established constitutional doctrines validly be couched in the broadest terms. In fact, the de-

100. In the Curtiss-Wright case, 299 U.S. at 327-S, Mr. Justice Sutherland aaid:

"A legislative practice such as we have here, evidenced not by only occasional instances, but marked by the movement of a steady stream for a century and a half of time, goes a long way in the direction of proving the presence of unascailable ground for the constitutionality of the practice, to be found in the origin and history of the power involved, or in its nature, or in both combined.

"In The Laura [Pollock v. Bridgeport S. B. Co.] 114 U. S. 411, 416, this court answered a challenge to the constitutionality of a statute authorizing the Secretary of the Treasury to remit or mitigate fines and penalties in certain caecs, by repeating the language of a very early case (Stuart v. Laird, 1 Cranch 299, 309) that the long practice and acquiescence under the statute was a 'practical exposition . . . too strong and obstinate to be shaken or controlled. Of course, the question is at rest, and ought not now to be disturbed.' "

101. Mitchell, supra note 81 , at 62.

102. Accord: Wright, Constitutional Procedure in the United States for Carrying out Obligations for Mitititary Sanctions (1944) 38 A2r. J. INT. L. 678.

103. See Mitchell, supra note 81 , at 62. 
sirability of delegation of part of the war powers to the chief executive was called to Congress's attention by President Buchanan as long ago as $1859 .{ }^{104}$

Several distinct and well-established lines of authority establish the President's independent powers to make protective use of the armed forces of the United States, without awaiting a Congressional declaration of war or any other specific statutory authorization. ${ }^{105}$ All told, there are more than 100 examples of the extraterritorial use of limited military or naval contingents on the sole responsibility of the President. ${ }^{106}$ The constitutional "power and obligation" of the President to prevent invasion of American territory, to protect the interests of American citizens, and to fulfil guarantees made in international agreements or which are imposed by international law are the general sources of the authority for such action. ${ }^{107}$ Moreover, since treaties and other validly executed international agreements are the "law of the land" 108 to the same extent as statutes, the President is equally required and equally justified in using force, under appropriate conditions, to ensure their observance. ${ }^{109}$

Direct extraterritorial use of troops by the President has been found necessary to accomplish a series of diverse objectives. In the first

104. 5 Richardson, MEsSages, at 569-70.

105. In a letter to The Neru York Times (Nov. 5, 1944, § IV, p. 8, cols. 5-7) Messrs. John W. Davis, W. W. Grant, Philip C. Jessup, George Rublee, James T. Shotwell, and Quincy Wright rely heavily upon these independent powers to find authority for the President "to carry out a commitment for participation in international policing such as that proposed at Dumbarton Oaks." It is unnecessary, however, to decide whether these powers alone are adequate since the powers of the Congress may be superadded by joint resolution or act.

In his article in the American Bar Association Journal, cited supra note $81, \mathrm{Mr}$. Mitchell questions the relevance of the precedents of the independent Presidential use of troops on the ground that they do not establish any power to "initiate" war. On the practical level, it may be suggested that Mr. Mitchell is making an unworkable distinction between the purpose for which a President may use force and the possible effects of his use of force. On the legal level, it is possible to make reference to the concept of "limited war," adverted to by the six distinguished authors of the letter mentioned above, on the authority of the United States Supreme Court.

106. See the statements of Senator Austin and Professor Wright, U. S. News, Nov, 3, 1944, pp. 36, 38, 40.

107. See Wright, The Control of American Foreign Relations (1922) c. 16 and $\$ \S 126,151$; Taft, Our Chief Magistrate (1925) 85-7; Berdahl, War Poivers of tue Executive in the United States (1921) c. 3; Corwin, The President, at 240-50. Sec also statements cited supra note 106.

108. See Part I, Section VI. Except when contrary to statutes, established rules of international law are also the "law of the land." The Paquete Habana, 175 U. S. 677, 700 (1900).

109. George Washington initiated preventive measures to stop aid to belligerents prior to enactment of the Neutrality Act of 1794, "under the general rules of international law. ... 1 PApers Relating to the Treaty OF Washington (1872) 55-7.

The administrations of Presidents Jefferson, Grant, Theodore Roosevelt, and Taft furnish additional examples of the doctrine that the President has the responsibility for directing compliance with international law doctrines save where contrary statutes have been enacted. See, e.g., 11 Stat. 759 (1807); 16 Stat. 1135 (1870); 33 Stat. 2332 (1904); 
place, naval units have been used on various occasions to protect American commerce and shipping. Thus President Jefferson dispatched a naval squadron to the Mediterranean in 1801 to quell the Tripolitanean pirates; ${ }^{110}$ several battles were fought before Congressional approval was solicited and given. ${ }^{111}$ In 1831, President Jackson sent a cruiser to the Falkland Islands, then an Argentinian possession, to prevent interference with American whaling ships.112 In 1861, the United States joined with Great Britain, France, and the Netherlands in sending an expedition to open to shipping, pursuant to treaty rights, the Japanese straits of Shimonoseki. ${ }^{113}$ On other occasions during the nineteenth century it has been found necessary to land limited contingents of troops, usually after naval bombardments, to destroy the hideouts of pirate gangs which had been preying on American vessels. ${ }^{114}$

In the second place, on a great many occasions troops or contingents of armed sailors have been landed in other countries to protect the lives or property of American citizens. Such action has occurred with the greatest frequency in Latin America, especially during revolutions, but it has also been found necessary in the South Sea Islands and Africa, prior to the incidence of European control, and in the Near and Far East. ${ }^{115}$ Discussing the President's power to send troops overseas to safeguard American interests in his classic treatise, The Diplontalic Protection of Citizens Abroad, Professor Borchard declared:

"Inasmuch as the Constitution vests in Congress authority 'to declare war,' and does not empower Congress to direct the President to perform his constitutional duties of protecting American citizens on foreign soil, it is believed that the Executive has unlimited authority to use the armed forces of the United States for

37 Stat. 1719 (1911). In all these cases, the Presidential proclamations contained prohibitions upon the access of foreign vessels to American ports which excoeded those contained in the relevant statutes.

Indeed, in the Alabama Claims arbitration, the United States tool the position that in the event of a deficiency of municipal law, the chief executive of a nation was charged with the duty of seeing that obligations incurred by international agreements or conventional international law were respected. 3 P.APERs, supra, at 19-20.

110. See 3 McMister, History of the Peofle of the Uatted States (1928) 201 et seg. Jefferson's defense of his conduct is contained in the message transmitted to Congress on December 8, 1801. 1 Richardson, Miessages at 326 el seq.

111. 2 STAT. 129 (1802).

112. See Offutt, The Protection of Citizens Abro.jd bX tee Amued Forces of ine United States (1928) 20-2; 1 Moore, Digest, at 29S-9.

113. 5 MIOORE, Digest, at 745-50; OFFUTT, op. cil. supra note 112, at 45-8.

114. See BerdaAl, op. cit. supra note 107, at 46; DEP'T of State, Rigkt to Protrct Citizens in Foreign Countries by Landing Forces (1934) 51, 53, 57; Orfetr, op. cit. supra note 112, at 17-20. The work last cited contains valuable summaries of many of the situations when troops or naval vessels were used to protect American citizens or property:

115. See, e.g., DeP't of State, op. cil. supra note 114 , at $57,60,61,62,65,63,69,71,72$, 74, 77, 129-30; 2 Moore, Digest, at 400-2, 414-8; Corwin, THe Preside:it's Conitsol of Foreign Relations (1917) 160-3. 
protective purposes abroad in any manner and on any occasion he considers expedient." 116

It is probable that few will deny that the stake of the American people in averting the outbreak of military conflict is at least as great and as deserving of prompt executive action as their interest in protecting the rights of a few expatriates. In point of fact, direct Presidential action has often had far more important purposes. Thus several Presidents found it appropriate to move troops or battleships to Panama, Cuba, and Haiti pursuant to general obligations embodied in treaties. ${ }^{117}$ In 1919, a Marine contingent was landed in Dalmatia to prevent the outbreak of hostilities between two of our erstwhile World War allies, Italy and the nascent Yugoslav kingdom. ${ }^{118}$ The desire to "resist the Japanese penetration of Northern Manchuria and Siberia" under guise of combatting Bolshevism was "first and last" the purpose of the expeditionary force sent to Siberia in 1918 by President Wilson. ${ }^{119}$ The force remained overseas for almost two years. ${ }^{120}$

116. Borchard, Diplosiatic Protection of Citizens Abroad (1916) 452. Professor Borchard further stated: "It is true that President Buchanan took a contrary view of his duties, and that Congress has on various occasions, by Act and Joint Resolution, directed or authorized the President to employ the military forces of the United States in the protection of the interests of American citizens abroad; yet in view of the above, it seems that such authorization is entirely unnecessary, if not without constitutional warrant." Ibid.

It should be noted, however, that Professor Borchard apparently believes that the delegates to the Security Council vice the President should not be permitted to commit the use of American troops without reference to Congress. See U. S. News, Nov. 4, 1944. Professor Borchard's statement as to the "constitutional" duty of the President to protect American citizens extraterritorially is, of course, sustainable only on the thesis that Article II, Section 1 contains a plenary grant of power to the Executive or on the "inherent" power rationale.

117. In his message recognizing the existence of the Republic of Panama, Theodore Roosevelt called attention to the several occasions when troops had been landed on the Isthmus. Some of the occasions when troops were sent to Cuba, Haiti, and Santo Domingo are summarized in 2 HACKWORTH, DIGEST, at 327-30.

The right to land troops in Cuba to safeguard that nation's independence and ensure orderly government was created by the Treaty of May 22, 1903, and abrogated by tho Treaty of May $22,1934.48$ STaT. 1682 (1934). The right to land troops in Haiti for approximately the same reasons was created by the still operative Treaty of Sept. 16, 1915, 39 STAT. 1654 (1915).

118. See BERDAHL, op. cit. supra note 107, at 56; N. Y. Times, Oct. 2, 1919, p. 19, col. 3, and Oct. 3,1919, p. 17, col. 3. Authorization for the landing of troops can hardly be derived from the fact that, technically speaking, the United States was still at war with the Central Powers, as the conflict sought to be averted was between two of our allies. Enforcement of rights promised the United States was involved in the Shimonoseki expedition. See note 113 supra.

119. See Griswold, The Far Eastern Policy of the United States (1941) 226-7. See also $i d$. at 227-38; Wilson's contrary official explanation of the expedition is reported in Sen. Doc. No. 60, 66th Cong., 1st Sess. (1919). See also Graves, America's Siberian ADVENTURE (1931) 42-9 and passim. On the other hand, our participation together with Great Britain and France in the Murmansk expedition in 1918 seems to have been wholly motivated by the desire to protect supplies and to assist the Russian Whites to fight the Germans so as to relieve pressure on the western front. See GriswOLD, supra, at 226.

120. See Griswold, op. cit. supra note 119, at 233. 
Presidential dispatch of forces overseas without express Congressional authorization has often resulted in collaboration between American units and contingents from other States in the protection of shipping, property or treaty rights. ${ }^{121}$ The classic example of the use of an international police force is the Boxer expedition to China in 1900. President McKinley did not wait for Congressional authorization before sending the American contingent of 15,000 soldiers to fight under an internationally designated commander-in-chief, to help in "preventing a spread of the disorders or their recurrence." 122

A final and important basis for independent executive power is the doctrine that the President possesses concurrent authority with Congress to recognize the existence of a state of war imposed upon the United States or to act in an emergency to repel or avert an invasion of the United States. The Committee on Detail at the Constitutional Convention originally proposed to give Congress the power "to make war." On motion of Madison and Gerry, the word "declare" was substituted for the word "make," for the express purpose of giving ". . . the Executive the power to repel sudden attacks." ${ }^{123}$ On several occasions, Presidents have acted boldly to repel actual or threatened invasion of the United States or threats to our national safety. Thus, in 1793, President Washington, acting entirely on his own initiative, directed General Wayne to drive out of the Northwest Territory any British troops which might be found stationed there. In 1814, 1817, and 1818, under the orders of Presidents Madison and Monroe, a series of American generals invaded Florida to suppress English marauders, freebooters and Indian tribes, who periodically raided American settlements and were not effectively controlled by Spain, the then nominal sovereign of the area. ${ }^{124}$ In 1846 , President Polk directed General Taylor not only to repel any Mexican invasion of disputed territory, but to follow the invaders into admitted Mexican territory until they were defeated; it was only after two battles had been fought that Congress was called upon to "recognize the existence of war." 123

121. See list in Dep't of State, op. cit. stupra note 114, at 3i. See aleo Collez, Hrstony OF THE U. S. MARINE CORPS (1903) 232-3.

122. See Dennett, John Hay (1934) cc. 24-6; Elinu Root, Mimitary ard Coloninl Policy of tHe UNITEd States (1916) 333, 336-47. The quotation in the test is from a message by President Mickinley. Foreign Relatrons: 1900 at xiv. See also Frve Ycurs of the War Departirent, 1899-1903, as Shown in the ANzulal Reforts of tae SecreTARY OF WAR (1904) S6-96.

Other purposes of the expedition were the protection of the lives of citizens and property in North China and the maintenance of treaty rights.

123. Míadison, Debates, at 418 .

124. See Fist, American Diplomicy (1938) 200-1, 234: 5 Moore, Internationil ARbitrations (1898) 4519-24, respectively.

125. 1 The Diary of James K. Polf during mis Presiderscy (Quaife, ed., 1910) 9-13; Berdahl, War Powers of the Executrve in the Untred States (1921) 70-4; 1 BeveRIDGE, AbRaham LincolN, 1S09-185S (1928) 422. The year before, when Tesas was still an 
In 1916, President Wilson sent troops into Mexico under command of General Pershing in an attempt to apprehend the bandit leader Villa, who had been raiding borer towns; the expeditionary force remained in Mexico for eight months. ${ }^{126}$

By far the most important of the instances of direct executive action is President Lincoln's conduct at the beginning of the Civil War. For three months after the fall of Fort Sumter President Lincoln failed to convene Congress; during the interregnum, he declared a blockade of the southern states, increased the size of the army and navy without statutory authority, and directed the commencement of retaliatory military moves. ${ }^{127}$ These exercises of executive power were ratified by Congress, and approved by the Supreme Court in The Prize Cases and other decisions. ${ }^{128}$

Now that the technology of war has made it imperative in the interests of national safety that aggressors be met with the threat of overwhelming force before they can commence their own military operations, it can scarcely. be doubted that the President possesses the authority to take whatever action is necessary to protect the interests of the United States in a threatened emergency. ${ }^{129}$ As long ago as 1827 the Supreme Court, in dealing with the powers of the President to call

independent nation, President Tyler had threatened to use force if any other power, i.e., Mexico, invaded its territory, because of the "inchoate interest of the United States." 4 Richardson, MEsSages, at 317-8.

126. See Callahan, American Foreign Policy in Mexican Relations (1932) 561-74; 2 Hackworth, Drgest, at 291-8. Congressional approval was obtained by President Wilson, but only after Pershing's troops had crossed the border.

127. See Fish, The American Civil War (1937) 303-5; Randali, Constitutional Problems under Lincoln (1926) 36-41; Corwin, The President, at 156-8.

128. The Prize Cases, 2 Black 635 (U. S. 1863). See also The Protector, 12 Wall. 700 (U. S. 1871); United States v. The Francis Hatch, 25 Fed. Cas. 1201, No. 15,158 (D. Md. 1864).

129. This conclusion is re-enforced by the principle-most explicitly formulated by Lincoln during the Civil War-which authorizes the President to exercise in a period of grave national crisis any appropriate powers not directly forbidden by the Constitution. The doctrine and its necessity have never been more clearly phrased than in a letter sent by Lincoln to a critic in 1864:

"I felt that measures, otherwise unconstitutional might become lawful by becoming indispensable to the preservation of the Constitution through the preservation of the Union."

Quoted in Sutherland, Constitutional Power and World Affairs (1919) 96. Sce also Randall, Constitutional Problears under Lincoln (1926) 512-5.

This principle, supported also by Presidents Jefferson [see 11 Writrngs of Tuomas Jefferson (Ford, ed., 1904) 146], Theodore Roosevelt [see PringLe, Theodore Roosevelt (1931) 260,274], and Woodrow Wilson, was approved by the Supreme Court in The Prize Cases, 2 Black. 635 (U.S. 1863) and extended to Congressional power in 1871 by the decision in Knox v. Lee, 12 Wall. 457 (U. S. 1870). The abstract question of whether a peace-time emergency enlarges federal powers has been befogged in judicial logomachy. Sce, e.g., Schechter v..United States, 295 U. S. 495 (1935); Home Building \& Loan Ass'n v. Blaisdell, 290 U. S. 398 (1934); Block v. Hirsch, 256 U. S. 135 (1921); Marcus Brown Holding Co. v. 
out the militia and employ the armed forces of the United States, concluded that he was empowered to act not only in cases of actual invasion, but also when there was "imminent danger of invasion." 100 This latter contingency was held to be a question of fact to be determined by the President. ${ }^{131}$ Similarly, the logic of the Civil IVar Prize Cases lead ineluctably to the conclusion that the President may recognize the existence or imminence of a war, which threatens American interests, before there is an actual invasion of our territory; ${ }^{132}$ for the whole tenor of Justice Grier's majority opinion is that the existence of war is a question of fact and that the President must meet the danger "in the shape it presented itself, without waiting for Congress to baptize it with a name. . . . 'He must determine what degree of force the crisis demands.' " 133

The broad powers of the Congress make it unnecessary, however, to attempt any exact delimitation of the powers of the President to use the armed forces of the United States on his own initiative. IThen to the President's own powers are added the powers that the Congress may delegate to him, the total is clearly sufficient to permit the most effective implementation of the United States' participation in any international security organization.

The traditional and wise bias of the United States against inflation of executive power necessarily impels us all to recoil to some extent at the thought of conferring or recognizing in the President the power to utilize military sanctions against an aggressor. "TVe fear to grant power," said Mr. Justice Holmes in a memorable dissenting opinion, "and are unwilling to recognize it when it exists." 134 Yet in an age of rampant dictatorships and galloping progress in the invention of new instruments of destruction an increase in emergency executive power has become a national life insurance policy. The revival, especially by Germany and Japan, of the practice of beginning war without benefit of a formal declaration, and sometimes even during the course of international negotiations, intensifies the practical problem. ${ }^{135}$ In

Feldman, 256 L. S. 170 (1921); United States v. Cohen Grocery Co., 255 U. S. $\$ 1$ (1921). But there has been no retreat from the position that the Federal Government, through the chief executive or otherwise, possesses almost plenary powers when the national esfety is threatened. See Wilson v. New, 243 U. S. 332 (1917): Block v. Hirsch, stfpra: United States v. Gordin, 287 Fed. 565 (S. D. Ohro 1922). See also Culp, Esecutire Parcr in Encrgencies (1933) 31 Mich. L. Rev. 1066.

130. Martin v. Mott, 12 Wheat. 19, 28 (U. S. 1S27).

131. Ibid.

132. Compare Cormn, The President's Control of Foneign Rexhtroms (1917) 141-2.

133. 2 Black $635,669-70$ (U. S. 1S63).

134. Tyson v. Banton, 273 U.S. 418,445 (1927).

135. The practice of initiating general hostilities without a formal declaration of war was prevalent from 1700 to 1870 . See Evans, Leadisg Cises on Iriteriationar Lat 
the words of Charles Beard, "Since the United States is in no position to limit the powers of other nations, it should set no limits to the powers of its Government to deal with them, save that of ultimate responsibility to the nation from which its authority is derived." 136

From a realistic standpoint, the proposal to vest in the President the power to use economic and military sanctions is, moreover, not so much a departure from tradition as a frank recognition of the longevident realities of diplomatic practice. The President, as the "sole organ of the nation in its external relations" has always tended to dominate our foreign policy, and has always possessed the power to bring the country to war, if he so chose. ${ }^{137}$ Yet this de facto concentration of power has actually been used to forestall declarations of war. Thus competent scholars believe President Adams blocked the conversion of limited naval hostilities against France in 1798 into a general war, that Presidents Jefferson and Johnson averted war against England in 1807 and 1868-1869; similarly President Wilson ignored the clamor for long-term occupation of Mexico in 1916 and 1917.138

The San Francisco proposals, moreover, leave the choice of methods whereby members shall meet the calls of the Security Council for imposition of embargoes or provision of quarantining forces to the individual nations. ${ }^{139}$ The task of drafting the act of adherence to an international security organization and the statutes regulating the powers of the President so as to vest him with complete leeway in dealing with aggression in some parts of the world or when initiated by certain nations and with considerably less freedom of action in dealing with other situations is by no means insuperable. If, even after such

(1922) 386. Beginning with the Franco-Prussian War in 1870, it became the custom to precede hostilities with a declaration; this was done by all the major States in the first World War. See id. at 387. The practice was declared obligatory by the Hague Convention of 1907. See Scott, Hague Conventions and Declarations of 1899 and 1907 (1915) 96.

However, the Japanese initiated hostilities in the 1894 war against China and the 1904 war with Russia without formal declarations. See Holland, Studies IN InTERnational Law (1898) 115; 2 Cobbett, Cases and Opinions on International Law (1913 ed.) 1 et seq. Subsequent to the German invasion of Poland in 1939, begun while, like the attack on Pearl Harbor, peace negotiations were presumably being conducted, the Axis powers commenced hostilities against most of their present adversaries without bothering to declare war. See Gathorne-Hardy, A Short History of International Afrairs (1942) 498-9; (1941) 4 Dep't of State Bull., No. 82, pp. 89-90.

136. BEARD, The Open DoOR at HOME (1935) 298-9: See also quotation from this work in Part I, Section II, note 67.

137. See BERDAHL, op. cit. supra note 125 , at 80-95.

138. See, e.g., BAssetT, The Federalist Svstem (1906) 251; 3 MCMaster, History of the People of tee United States (1928) 262; Dunning, Reconstruction: Political AND ECONOMIIC (1907) 160-2; RHODES, HISTORICAL ESSAYS (1909) 218-9; BERDAHL, op. cil. supra note 125, at 83-4; Nevins, Hamilton Fisn (1937); Calladan, AMERICAN Foreign Policy in MeXican Relations (1932) 562-73.

139. See Charter, c. VII, art. 43 , par. 3. 
draftsmanship, the ultimate check on the Executive's power is his own sense of self-restraint, ${ }^{140}$ surely the history of the United States affords every reason to believe that powers given to permit rapid action in an emergency will be used as sparingly as possible. Except in case of imperative self-defense, it is to be assumed that no President will commit the use of American troops without prior consultation of Congress. If direct action by the President will sometimes be necessary, it is again to be assumed that, as soon as possible, the situation will be explained to Congress and its views sought.

Twenty-five years ago Woodrow Wilson said: "I can predict with absolute certainty that within another generation there will be another World War, if the nations of the world do not concert the method by which to prevent it." ${ }^{141}$ There has been given to the generation which saw its safety and freedom totter perilously in the balance on the dubious battlefields of El Alamein and Stalingrad a second opportunity to create the foundations of enduring peace and prosperity and to prevent the recurrence of global war. If we allow ourselves to fail again because of the obstructionist tactics of a small group of wilful men, archeologists of the future who dig into the ruins of our civilization will have cause for astonishment that a nation which had throughout its history been so successful in making words serve their appropriate purposes should suddenly have become so hypnotized by a single, absolutist notion of the one word "treaty" that it could not see the full meaning, in both reason and tradition, of the many other relevant words of its fundamental charter. ${ }^{142}$

140. Compare dissenting opinion of Mr. Justice Stone in United States v. Butler, 297 U.S. 1,78 (1936).

141. Mahon, Our Second Chance (1944) 6.

142. In 4 Ofnion NEws (National Opinion Research Center) No. 3, Feb. 6, 1945, there is summarized a poll by the American Institute of Public Opinion sihich indicates that in response to the question, which of "these three ways would you, personally", favor as the best way to have peace treaties approved after the war," $S \% 0$ answered "Approval only by President," 58\% "Approval by President and majority of rhole Congress," 22\% "Approval by President and tro-thirds of Senate," and 12\% "Don't know." See also American Inctitute of Public Opinion. Public Opinion Newr Service, Releace, May 17, 1914; Juticisry Committee Hearings at 31. 